\title{
Molecular and serological characterization of $p$ fimbriae from uropathogenic escherichia coli
}

Citation for published version (APA):

de Ree, J. M. (1986). Molecular and serological characterization of $p$ fimbriae from uropathogenic escherichia coli. [Doctoral Thesis, Maastricht University]. Rijksuniversiteit Limburg. https://doi.org/10.26481/dis.19861219jr

Document status and date:

Published: 01/01/1986

DOI:

10.26481/dis.19861219jr

Document Version:

Publisher's PDF, also known as Version of record

\section{Please check the document version of this publication:}

- A submitted manuscript is the version of the article upon submission and before peer-review. There can be important differences between the submitted version and the official published version of record.

People interested in the research are advised to contact the author for the final version of the publication, or visit the DOI to the publisher's website.

- The final author version and the galley proof are versions of the publication after peer review.

- The final published version features the final layout of the paper including the volume, issue and page numbers.

Link to publication

\footnotetext{
General rights rights.

- You may freely distribute the URL identifying the publication in the public portal. please follow below link for the End User Agreement:

www.umlib.nl/taverne-license

Take down policy

If you believe that this document breaches copyright please contact us at:

repository@maastrichtuniversity.nl

providing details and we will investigate your claim.
}

Copyright and moral rights for the publications made accessible in the public portal are retained by the authors and/or other copyright owners and it is a condition of accessing publications that users recognise and abide by the legal requirements associated with these

- Users may download and print one copy of any publication from the public portal for the purpose of private study or research.

- You may not further distribute the material or use it for any profit-making activity or commercial gain

If the publication is distributed under the terms of Article $25 \mathrm{fa}$ of the Dutch Copyright Act, indicated by the "Taverne" license above, 
MOLECULAR AND SEROLOGICAL CHARACTERIZATION OF FIMBRIAE FROM UROPATHOGENIC ESCHERICHIA COLI 


$$
8
$$




\title{
MOLECULAR AND SEROLOGICAL CHARACTERIZATION OF P FIMBRIAE FROM UROPATHOGENIC ESCHERICHIA COLI
}

\author{
PROEFSCHRIFT \\ ter verkrijging van de graad van doctor in de geneeskunde \\ aan de Rijksuniversiteit Limburg te Maastricht, \\ op gezag van de Rector Magnificus, Prof. Dr. F.I.M. Bonke, \\ volgens besluit van het College van Dekanen, \\ in het openbaar te verdedigen op \\ vrijdag 19 december 1986 om 16.00 uur \\ door \\ Johannes Mathijs de Ree \\ geboren op 16 juni 1956 te Sittard
}

Druk: Krips Repro Meppel

1986 
promotores : Prof. Dr. C.P.A. van Boven Prof. Dr. H.A. Valkenburg

copromotor : Dr. J.F, van den Bosch

referenten : Prof. Dr. W.P.M. Hoekstra

Prof. Dr. F. Bosman

The present investigations were supported by the Dutch Kidney Foundation (grant no 81320). 
aan mijn ouders, acon Jeanne te 


\section{Page}

Chapter 1

Introduction

11

Chapter 2

Molecular cloning and characteri-

24

zation of $F 9$ fimbriae from a uro-

pathogenic Escherichia coli

Chapter 3

Molecular cloning of Fll fimbriae

31

from aropathogenic Escherichia

coli and characterization of fim-

briae with polyclonal and mono-

clonal antibodies

Chapter 4

Monoclonal antibodies that recog-

nize the $P$ fimbriae $F 7_{1}, F 7_{2}$, F9

and F11 from uropathogenic

Escherichia coli

Chapter 5

Characterization of the $P$ fimbriae

F8 and Fl2 from uropathogenic

Escherichia coli with monoclonal

antibodies

Chapter 6

Monoclonal ant 1 bodies ralsed

against Pap fimbriae recognize

minor component (s) involved in

receptor binding

Chapter 7

Monoclonal antibodies for sero-

70

typing the p fimbriae of uro-

pathogenic Escherichia coll 
Chapter 8

Chapter 9

Chapter 10
Pimbriae serotypes of

Escherichia coll stralus isolated

from extra intestinal infections

Serological response to the $P$

fimbriae of uropathogenic

Escherichia coli in pyelonephritis

General and Sumarizing Discussion

Samervatting

106

Dankwoord

108

Curriculum vitae

111 
This thesis is based on the following papers.

The contents of the chapters $2-9$ correspond to the papers $1-8$, respectively.

1. de Ree JM, P Schwillens, L Promes, I van Die, H Bergmans, and JF van den Bosch. 1985. Mollecular cloning and characterization of fíf fibriae from a uropathogenic Escherichia colf. EEMS Microbiol. Lett. 20: 163-169.

2. de Ree JM, $P$ Schwillens, and JF van den Bosch * 1985. Molecular cloning of Fll flmbriae from a uropathogenic kscherichia coli and characterization of fimbriae with polyclonal and monoclonal antibodies. FEMS Microbiol. Lett. 29: $91-97$.

3. de Ree JM, P Schwillens, and JF van den Bosch. 1985. Monoclonal ant1bodies that recognize the $\mathrm{P}$ fimbriae $F 7_{1}, F 7_{2}, F 9$ and $F 11$ from uropathogenic Escherichia coli. Infect. Immun. 50: 900-904.

4. de Ree JM, K Jann, and JF van den Bosch. 1987. Characterization of the $P$ fimbriae F8 and F12 from uropathogenic Escherichia coli with monoclonal antibodies. Submitted for publication.

5. de Ree JM, P Schwillens, and JF van den Bosch. 1987. Monoclonal ant1bodies raised against Pap fimbriae recognize minor component(s) involved in receptor binding. Microbial Pathogenesis 2: in press.

6. de Ree J, P Schwillens, and JF van den Biosch. 1986. Monoclonal antibodies for serotyping the $\mathrm{P}$ fimbriae of wropathogenic Eschertchia coll. J. Clin. Microbiol. 24: 121-125.

7. de Ree JM, and JF van den Bosch. 1987. Fimbriae serotype of Eschertchia coli isolated from extra intestinal infections. Submitted for publication.

8. de Ree JM, and JF wan den Bosch. 1987. Serologlcal response to the $P$ fimbrlae of uropathogentc Escherichia coll in pyelonephritis. Submitted for publication. 


\section{INTRODUCTION}

Infections of the urinary tract are common all over the world and occur in people of all ages and both sexes. Looking at urinary tract infections (UTI) two observations can be made. First of all the high prevalence of UTI in healthy populations all over the world. Secondly, the morbidity of UII has remained stable in spite of the use of antibiotics. These observations resulted in an increased interest for the pathogenesis of UTI. UTI caused by bacteria can be distinguished in three groups: asymptomatic bacteriuria, cystitis and pyelonephritis. This classification is mainly based on the presence of signiflcant bacteriuria and clinical symptoms. Significant bacterluria refers to the presence of more than $10^{5}$ bacteria per ml of urine (1).

Asymptomatic bacteriuria (ABU) has been Investigated intensively. Studies among schoolch1ldren have revealed that the prevalence of $A B U$ is $1 \%$ in girls and $0.03 \%$ in boys $(2,3)$. It could al so be demonstrated that five percent of the adult female population have a UTI at any one time, whereas it is estimated that women during their life have a 50 percent chance of acquiring a UTI (4). UTI are among the most common medical complications in pregnancy. Approximately $6 \%$ of pregnant women develope an $A B U$, which migh have an effect on maternal and foetal health (4-6). More than 50\% of this ABU will develop Into symptomatic UII and even 30-40\% will develop a pyelonephritis $(5-7)$.

The prevention of renal damage is an Important reason for treating UTI. The main target populations are infants and small children. There $1 \mathrm{~s}$ evidence that kidney damage associated with UII arlses in childhood, which can lead to progressive kidney damage, higher blood pressure and even kidney fallure (9, 10). Whereas the development of kidney scarring is the main problem in children, In elderly people the bacteria can spread to the blood stream and can 
cause a fatal septlcaemia. It has been estimated that hall of all gram-negatrue septicaenila origlnate in the urlnary tract (11). Another problem associated Wth UTI 16 morbidity. UTI cause much misery and is among the main causeg of female absence from work $(8)$. The increasing employment of women makes this problem nowadays even greater.

The creatment of UTI Inwolves the use of large quantities of antibacterial agents. Which accounts for great expenses. An important disadvantage of the use of antiblotics is that it could interfere th the normal bacterial flora. It could moreover result in the selection of resistant organisin.

The normal urinary tract is sterile above the level of the distal urethra. Two routes of Infections of the urinary tract can be distinguished: the haematogenous and the ascending route. By the haematogenous route the organlsms origlnate from an infection elsewhere in the bady and enter the urimary tract wa the blood stream (12). However, the haematogenous route of infection 1s very rare and will not be discussed. Urinary tract infections occur mainly by the ascending route. Organisms from the bowel colonize the periurethral zone and from hereon the urinary tract. In view of the anatomical and physiological differences between males and females it is not surprising that the prevalence of UTI in females exceeds that in male (13). The shortness of the female urethra which facilitates entry of organisms as well as the lack of prostatic secretions, which contains a bactericidal substance, are two relevant points which could explain the sex dfference in prevalence of UTI.

To colonize the urinary tract the organisms have to overcome a hydrokinetic and a mucosal defensive mechanism (14). The hydrokinetic defenstve mechanism is based upon the wash-out of bacteria by periodic voiding and dilution by inflow of urtne from the kidney. The mucosal defense mechanism is based upon a bactericidal effect of the intact bladder mucosa. It was suggested that a phagocytic mechanism accounts for this defense mechanism, however no such phagacytic mechandsm could be demonstrated (14).

The organism most commonly fsolated from all types of UTI is Escherichia colt (15). As already mentioned these E. coll orlginate from the own bowel flora. Two theorles have been proposed about the nature of the infecting E.coli stralins. The prevalence theory states that the strains responsible for UTI are simply those that predominate in the faeces. This theory $1 \mathrm{~s}$ based on the fact that E.coll isolated from UTI belong to a restricted range of serogroups and the prevalence of these serogroups is similar to that in the 
faeces. On the other hand the special pathogenicity theory states that the Infecting E.coll strains have special pathogenic features. At present this spectal pathogenicity theory is generally accepted and several virulence factors have been determined to be inwolved in the pathogenesis of UTI. The most important virulence factors are the $0: K$ serotype, haemolysis and the adhesive capacity of the uropathogenic E. coli. These three properties will be considered now in more detail.

\section{0: K serotype}

The outer membrane of $\mathrm{E}$. coli is a typlcal feature of Gram-negative bacteria and it contains lipids, proteins and lipopolysaccharides (LPS). Some of these components are exposed on the cell surface and can interact with the enviroment. The LPS are build up by a lipid A part, a core part and a polysaccharide molety. The chemical structure of these polysaccharides is the molecular basis of the serological specificity and is called the bacterial 0 specificity. So far more than 1600 antigens have been described.

A relative small rumber of o groups, namely 01, 02, 04, 06, 07, 018 and 075, have been reported to account for a major part of uropathogente $\mathbb{E}$. coll strains $(2,16,17)$. It was also demonstrated that these a serotypes were very frequent among pyelonephritis, less among cystitis, and the least among ABU strains (18). In addition strains isolated from pyelonephritis without reflux belong more frequently to these o serogroups than strains from pyelonephritis with reflux $(19,20)$. This suggests that 0 antigens may be one of the virulence factors of E.coll in UTI.

Certain strains of E. coli are encapsulated with an extracellular acldic polysaccharlde. These capsules are termed $\mathrm{K}$ antigens. At this moment the existence of about 100 dfferent $\mathrm{K}$ antigens have been described. However only a limited range of these $K$ ant 1 gens $(K 1, K 2, K 3, K 12$ and $K 13)$ is found with significant frequency in UTI $(17,21)$. It was demonstrated that the firequency of $K$ antigens is higher in stralns isolated from pyelonephrits than from cystitis (22). The presence of $\mathrm{K}$ antigens favoured also kidney invasion in a mouse model (23), especlally if they are present in large amounts (24). In addition strains causing pyelonephritis contaln more $K$ antigen than those causing cystitis $(22,25)$. The role of $K$ antigen $\mathbb{1 n}$ virulence has been suggested, among others, to be an inhibitor of phagocytosis $(26,27)$. 
Haemolysins are proteins which are produced by many Gram-negative and Grampostive bacteria and they are active against erythrocyces of various andmals and human Already in 1921 Dudgeon et a 1 .(28) pointed out that haemolytic E.coli strains are more comon among UTI stralns than among strains from the faecal flora, which was later confirmed by other groups $(29,30)$. The percentage of haemolytic strains isolated from pyelonephritis was higher than among cystitis or ABU strains (31). Furthermore, it was demonstrated that most of the haemolytic stralns belonged to the 0 serotypes $02,04,06$, 018 and $075(17,30,32)$.

The Influence of haemolysin production on virulence was studied in experimental mouse models. Van den Bosch et al. (33) concluded that haemolysin production was a virulence factor in most of the mouse nephropathogenic strains, when they were injected intravenously. They showed that 6 out of 7 stralns became awirulent after the elimination of haemolysin production. In another mouse model, where bacterla are introduced in the urinary tract via the bladder, Ketyl et al. (34) demonstrated that rough E. coll strains with haemolytic activity induced bladder and kidney infections whereas rough strains without haemolytic activity were non-virulent.

The genes for haemolysin production of E. coll strains lsolated from UTI are in most cases locallzed on the chromosome $(29,35)$, whereas many other haemolytic E. coll strains, particularly those from animal sources, are localized on a plasmid (36). Both types of haemolysin determinants were isolated by gene cloning and compared $(37,38)$. It was found that both types are closely related and consist of four genes (39). Two of these genes are required for aynthesis of active haemolysin and two for the transport of haemolysin across the outer membrane.

The mechanism and site of action of haemolysin is still obscure. Waalwijk et al. (40) have shown that haemolysin functions as a virulence factor by lyils of erythrocytes which increases the level of avallable iron in hematogenous pyelonephritis. It was also demonstrated that haemolysin is cytotoxic for fibroblasts and human leucocytes in vitro $(41,42,43)$. The combination of a toxic effect on varlous celis and the appearance of sufficlent iron may account for haemolysin as a virulence determinant. 
Adhesive properties of $\mathbb{E}$. coll were already recognized by Guyot in 1908 (44), when he observed that some E. coll strains could agglutinate red blood cells from a number of animal species. Duguid et al. (45) observed that haemagglutination (HA), in a number of instances, was correlated with the presence of fimbriae. This correlation between adherence, HA and the presence of fimbriae was later confirmed by others (46-49). However, it was also reported that there are $\underline{E}$. coli strains which do not express any fimbriae and st111 adhere $(50,51)$. This suggests the presence of nonfimbrial adhesins.

Three different classes of E. coli flmbriae have been described. The adhesion of these fimbriae is referred to as non-adhesive, mannose-sensitive (MS) and mannose-resistant (MR). The non-adhesive fimbriae (e.g. IC) do not show any HA as far as known. The IC fimbriae do not adhere to urinary epithelial cells or urinary mucus, whereas they adhere to buccal epithelial cells (52). Their role in UTI is st111 obscure. The MS fimbriae are usually referred to as type 1 fimbriae. These fimbriae recognize and bind specifically to D-mannose containing receptors. These receptors are present on guinea pig erythrocytes, yeast cells and the Tamm-Horsfall protein which $1 \mathrm{~s}$ found in urinary mucus $(53,54)$. More than $85 \%$ of al1 E. col1 stralins have the ability to express type 1 fimbriae. Until now no conclusive function has been determined for type 1 fimbriae. However, in some studies no correlation colld be found between the presence of type 1 fimbriae and virulence $(31,55)$.

A number of E. coll strains with varying MRHA patterns have been described. These E. coll strains express fimbriae which can be subdivided into four groups based on their receptor specificities. The group of $P$ fimbriae recognize a blood group $P$ assoclated receptor, a disaccharide with the structure $\alpha-\mathrm{D}-\mathrm{Galp}-(1-4)-\beta-\mathrm{D}-\mathrm{Galp}(56,57)$. The $M$ flmbrlae bind to a blood group $M$ associated receptor, which is a glycoprotein called glycophorin A (58). Another group of fimbriae which recognize the structure neuraminy1 2-3-galactoside as a receptor have recently been described and are called $s$ fimbriae (59). The last group of X flmbriae is a heterogenous group of fimbriae with varying $\mathrm{HA}$ patterns, but unknown receptor speciflctiles.

Among uropathogenic E. coll stralins especlally the $P$ fimbriae have been assoclated with the pathogenesis of pyelonephritis. This was based on clintcal studies $(60,61,62)$ which showed that approximately $90 \%$ of the $\mathbb{E}$. col1 strains isolated from children with an acute pyelonephritis express $P$ flm- 
bulae. For cystitis this flgure varied from $19 \%$ (60) t111 $31 \%$ (62), whereas only $14 \%$ of the $\mathrm{E} . \mathrm{coll}$ isolated from patients with $\mathrm{ABU}$ expressed $\mathrm{P}$ fimbriae $(60,61)$. However, it was also reported that $80 \%$ of the E.coli isolated from cystitis, and 64\% Erom ABU express $P$ flmbrlae (63). This suggests that this ad hesin may also play a role in lower UTI.

Another study by Lomberg et a1. (64) revealed that the incidence of $\mathbb{E}$. coll expressing $P$ ilmbriae $1 \mathrm{~s} 50 \%$ in patients with recurrent acute pyelonephritis and only $25 \%$ in such patients with vesicoureteric reflux. This means that when reflux is present no advantage $1 \mathrm{~s}$ conferred on $\mathrm{P}$ flubriated organisns, but presumably the reflux carries the organisms to the kidney.

The $P$ fimbriae may differ in the molecular welght of their subunit proteins and in serological specificities $(65,66,67)$. Orskov and orskov (66) have recently proposed a typlng scheme for $\mathbb{P}$ fimbriae of uropathogenic $E$. col1. By using polyclonal antisera raised against different $P$ fimbriae and crossed immuno electrophoresis they were able to distinguish elght serologicálly different $\mathrm{P}$ flmbriae on uropathogenic E. coll. They suggested to classify these $P$ fimbriae as F antigens (F7-F13). Another study by pary et al. (61), using polyclonal antisera in a slide agglutination test, demonstrated seven different antigenic determinants on fimbriae of uropathogenic $\underline{\mathrm{E} \text {. coli }}$ and designated them a to $g$.

\section{Outline of this study}

At the start of this study several serologlcally different fimbriae had been described on urinary E. coli strains, using polyclonal antisera. However, no studies were conducted to see which of these flmbriae are Important in the pathogenesis of UTI, especially pyelonephritis. The aim of this atudy was to characterlze these different flmbrlae with bllochemical and serologleal tools, and to investigate whtch of these fimbriae are important In the pathogenesis of pyelonephritis. Because most of the E. coll strains express varlous fimbriae, the genes encoding for certain types of fimbriae were cloned. In chapter 2 and 3 the molecular cloning of two different $P$ flimbriae is described. During the course of this study other investigators published the molecular cloning of other $\mathbb{P}$ fimbriae.

Characterization of polyclonal antisera raised against the various cloned and purifled $p$ fimbriae revealed that these $P$ fimbriae have many antigenic determinants in common. For this reason we produced a set of monoclonal 
antibodies ralsed against the various cloned and purifled f fimbriae, which were specific for the various $\mathbf{P}$ fimbriae.

The production and characterization of these monoclonal antibodies is described in the chapters 4-6. In chapter 7 the development of a proper wethod is described for the detection of $p$ fimbriae on clinical lsolates of uropathogenic $E$. coli with the aid of the monoclonal antibodies. With chis method various collections of extra intestinal E. coll were screened for the presence of different $P$ finbriae, which is described in chapter 8 . Finally, in chapter 9, the presence of antibodies agalnst $P$ fimbriae in the sera of patients with pyelonephritis was studied.

\section{Literature cited}

1. Kass, E.H. (1965) Asymptomatic infections of the urinary tract. Trans. Amer. Physns. 69: 56 .

2. Kunin, C.M., R. Deutscher, and A. Paquin. (1964) Urinary tract infection in school children: an epidemiologic, clinical and laboratory study. Medicine 43: $91-130$.

3. Kelly, D.G., F. Duff, S.F. Diskin, and S.F. Cahalone. (1969) Prevalence of urinary tract infection in Dublin school children. J. Irish Med. Ass. $62: 420-422$.

4. Kass, E.H., W. Savage, and B.A.G. Santamarina. (1965) The signiflcance of bacteriurla in preventic medicine. In: E.H. Kass (ed.) Progress in pyelonephritis. F.A. Davis, Philadelphia.

5. Kass, E.H. (1960) Bacteriuria and pyelonephritis in pregnancy. Arch. Intern. Med. 105: 194-198.

6. Brumfit, W. (1975) The effects of bacterlurla in pregnancy on maternal and fetal health. Kidney Int 8, Suppl.: S113-\$119.

7. Brumfit, W. (1981) The signiflcance of symptomatic and asymtotinatic Infections 1n pregnancy. In: G.M. Eisenbach and J. Brads (eds.) Kidney and pregnancy. Karger, Basel.

8. National Health Survey 1970-1971. Department of Health Publication, no. 73: 1508 .

9. Waters, W.E., P.C. Elwood, A.W. Asscher, and M. Abernathy. (1970) Clinical significance of dysuria in women. Brit. Med. J. 2: 754 . 
10. Asscher, A.W, and W. Waters. (1970) S1gniflcant bacteriuria la the non pregnant women. In: P. Kincaid-Snith and K.F. Fairley (eds.) Renal infection and renal scarring. Mercedes Publishing Services, Melbourne.

11. Asscher, (1980) The challenge of urinary tract infections. Academic Press, London.

12. Maske11, R. (1982) Urinary tract infection. L. Arnolds, London.

13. 0'Grady, F. (1976) Inttiation and ascent of urinary tract infections, p. 177-183. In: D.E. H1111ams, and G.D. Chisholm (eds.) Scientific foundations of urology, vol. 1 . Renal disorders, infections and calculi. W111am Heinemann Medical Books Ltd., London.

14. Cox, C.E., and $k^{*}$. Hilman. (1965) Factors in resistance to infection of the bladder. In: E.H. Kass (ed.) Progress in pyelonephritls. F.A. Davis, Philadelphia.

15. Cooke, E.M. (1974) Escherlchia coll and man. Churchi11 Livingstone, Ed inburgh.

16. Grskov, I., and Drskov. (1985) Escherlchia coll in extra intestinal infections, J. Hyg. 95: 551-575.

17. Van den Bosch, J.F., P. Postma, P.A.R. Koopman, J. de Graaff, and P.M. MacLaren. (1982) Virulence of urinary and faecal Escherichia call in relation to serotype, haemolysis and haemagglutination. J. Hyg. 88: $567-577$.

18. Lindberg, U., L.A. Hanson, U. Joda1, G. Lidin-Janson, K. Lincoln, and S. 0ling. (1975) Asymptonatic bacteriuria in school girls. II. Differences in Escherichia coli causing asymptomatic and symptomatic bacteriuria. Acta Paed. Scand. 64: 432-436.

19. Lomberg, H., M. Hellström, U. Jodal, H. Leffler, K. Lincoln, and C. Svanborg-Edên. (1984) Virulence associated strains in Escherlchia coll causing first and recurrent eplsodes of urinary tract infection in children with or without reflux. J. Inf. Dis. 150: 561-569.

20. Svanborg-Edén, C., U. Joda1, B. Kayser, H. Leffler, H. Lomberg, F. Orskov, and I. Orskov. (1985) Adhesive properties and $O, K, H$ and $F$ antigens of $\mathbb{E}$. coll assoclated wth recurrent pyelonephritis. In: Seminars in Infectious Diseases, vol. V. Bacterial vaccines (in press). 21. Kayser, B., L.A. Hanson, U. Jodal, G. Lidin-Janson, and J.B. Robbins. (1977) Frequency of $\mathbb{E}$. coll $\mathrm{K}$ antigens in urlnary tract infections in children. Lancet i: $663-664$. 
22. Kayser, B. (1973) Immunology of Escherichia coli $K$ antigen and its relation to urinary tract infection. J. Inf. Dis. 127: 670-677.

23. Kalmanson, G.M., H.J. Harwick, M. Turck, and L.B. Guze. (1975) Urinary tract infection; localisation and virulence of Escherichia coll. Lancet 1: $134-136$.

24. Nicholson, A.M. and A.A. Glymn. (1975) Investigation of the effect of $k$ antigen in Escherlchia coli urinary tract infection by use of a mouse mode1. Brit. J. Exp. Path. 56: 549-553.

25. McCabe, W.R., P.C. Carlings, S. Bruins, and A. Greely. (1975) The relation of $K$ antigen to the virulence of Escherichia coli. J. Inf. Dis. 131: 6-10.

26. Van Dijk, W.C. 1980. Escherichia coll infections; microbial virulence factors and phagocytic cell defence. Thesis. State University of Utrecht.

27. Verweij-van Vught, A.M.J.J., J.F. wan den Bosch, F. Namavar, M. Sparrius, and D.M. Maclaren (1983). K antigens of Escherichia coli and virulence in urinary tract infection: studies in a mouse model. J. Med. Microbiol. 16: 147-155.

28. Dudgeon, L.S., E. Wordley, and E. Bawtree. (1921). On Bac111us coli infections of the urinary tract, especially in relation to haemolytic organisms . J. Hyg . 20: 137-164.

29. Minshew, B., J. Jorgensen, G.W. Counts, and S. Falkow. (1978) Assoclation of hemolysin production, hemagglutination of human erythrocytes, and virulence of chicken embryos of extraintestinal Escherichia coll isolates. Infect. Immun 28: 359-367.

30. Cooke, E.M., and S.P. Ewlns. (1975) Properties of strains of Escherichia cali isolated from a varlety of sources. J. Med. Microblol. 8: 107-111.

31. Wălsănen-Rhen, V., J. Elo, E. Välsunen, A. Siltonen, I. Grokov, orskov, S.B. Svenson, P.H. Makela, and T.K. Korhonen. (1984) P-ftmbriated clones among uropathogenic kscherichia coli strains. Infect. Immun. 43: $149-155$.

32. Hughes, C., R. Phillips, and A.P. Roberts. (1982) Serum resistance among Escher chia coli strains causing urinary tract infection in relation to o type and the carriage of hemolysin, collcln and antiblotic resistance determinants. Infect. Immun. 35: 270-275. 
33. Van den Bogeh, J.F*, P. Postma, J. de Graafe, and D.M. MacLaren. (1981) Haemolysts by urinary Eschertchia coll and virulence in mice. J. Med. Microbiol. 14: $321-331$.

34. Kety1, I., G. Naumann, and W. Nimich. (1983) Urinary tract infectivity of a strains of Escherlchia coll carrying various virulence factors. Acta Microbio1. Acad. Scient. Hung. 30: 155-161.

35. Mullex, D., C. Hughes, and W. Goebe1. (1983) Relationship between plasmid and chromosomal hemolysin determinants of Escherichia coli. J. Bacterio1. 153: 846-851.

36. Goebe1, W., B. Royer-Pokora, W. Lindenmaier, and H. Bujard. (1974) Plasmids controlling synthesis of hemolysin in Escherichia col1: molecular properties. J. Bacterioll. 118: $964-974$.

37. Goebe1, $W_{*}$, and $J$. Hedgpeth. (1982) Cloning and functional characterization of the plasmid-encoded hemolysin determinant of Escherichla coli. J. Bacterio1. 151: 1290-1298.

38. Berger, H., J. Hacker, A. Juarez, C. Hughes, and W. Goebe1. (1982) cloning of the chromosomal determinants encoding hemolysin production and mannose-resistant hemagglutination in Escherichia col1. J. Bacteriol. 15:2; 1241-1247.

39. Wagner, W., M. Vogel, and W. Goebel. (1983) Transport of hemolysin across the outer membrane of Escherichla coli requires two functions. J. Bacteriol. 154: 200-210.

40. Waalwijk, C., D.M. MacLaren, and J. de Graaff. (1983) In vivo function of hemolysin in the nephropathogenicity of Escherichia coli. Infect. Immun * 42: $245-249$.

41. Cavalieri, S.J., and I.S. Snyder. (1982) Cytotoxlc activity of partially purifled Escherichia coll haemolysin. J. Med. Micrabiol. 15: 11-21.

42. Cavalier1, S.J., and I.S. Snyder. (1982) Effect of Escherlchia coli alpha-hemolysin on human peripheral leucocyte function in vitro. Infect. Immun. $37: 966-974$.

43. Gadeberg, O.V., I. Orskov, and J.M. Rhodos. (1983) Cytotoxic effect of an alpha-hemolytic Escherichia coll strain on human blood monocytes and granulocytes in vitro. Infect. Itmun. 41: 358-364.

44. Guyot, G. (1908) Ueber die bakterielle Haemagglutination (BakterioHaemo-agglutination) * Zentralblatt für Bakteriologle, Parasitenkunde, Infektlonskrankheiten und Hyglene, Abtellung I: Origlnale 47: 640-653. 
45. Duguid, J.P., I.W. Smith, G. Dewpster, and P.N. Edmunds. (1955) Nonflagellar filamentous appendages ("flmbriae") and haemagglutinating activity in Bacterium coll. J. Pathol. Bacteriol. 70: $335-348$.

46. Swanborg-EdÉn, C., L.A. Hanson, U. Jodal, U. Lindberg, and A.S. Akerlund. (1976) Variable adherence to normal human urfoary tract epithelial cells of Escherichia coli strains assoclated with various forms. of urinary tract infection. Lancett il: 490-492.

47. Kallenius, G., and R. Mollby. (1979) Adhesion of Escherichia coll to human periurethral cells correlated to mannose-resistant agglutination of human erythrocytes. FEMS Microbiol. Lett. 5: 295-299.

48. Van den Bosch, J.F., U. Verboom-Sohmer, P. Postma, J. de Graaff, and D.M. Maclaren (1980). Mannose-sensitive and mannose-resistant adherence to human uroepithelial cells and urinary virulence of Escherlchia coli. Infect. Immun. 29: 226-233.

49. Salit, I.E., and E.C. Gotschlich (1977). Type 1 Escherichia col1 pil1: characterization of binding to monkey kidney cells. J. Exp. Med. 146: $1182-1194$.

50. Labigne-Rousse1, A.F., D. Lark, G. Schoolnik, and S. Falkow. (1984) Cloning and expression of an aflmbrial adhesin (AFA-1) responsible for $P$ blood group-independent mannose-resistant hemagglutination from a pyelonephritic Escherichia coli strain. Infect. Immun. 46:251-259.

51. Goldhar, J., R. Perry, and I. Ofek. (1984) Extraction and properties of nonfimbrial mannose resistant hemagglutinin from a urinary 1solate of Escherichia coli. Current Microblol. 11: 49-54.

52. Orskov, I., F. Orskov, A. Birch-Anderson, M. Kanamori, and $\mathbb{C}$. Svanborg-Edén. (1982) $0, \mathrm{~K}, \mathrm{H}$ and fimbrial antigens in Escherlchla coli serotypes associated with pyelonephritis and cystitis. Scand. J. Infect. Dis. Suppl. 33: 18-25.

53. Drskov, I., A. Ferenc, and F. Orskov. (1980) Tamm-Horsfall protein or uromucoid is the nomal urinary slime that traps type $\mathbb{1}$ fimbriated Escherlchia col1. Lancet 1: 887 .

54. Duguid, J.P., and D.C. Old. (1980) Adhesive properties of Enterobacterlaceae, p. 185-217. In: E.H. Beachey (ed.) Bacterial adherence. Receptors and recognition series B, vol. 6. Chapman and Hal1, London. 
55. Hagberg, L., U. Jodal, T.K. Korhonen, G. Lidin-Janson, U. Lindberg, and C. Svanborg-Eden. (1981). Adhesion, haemagglutination, and virulence of Escherlchla coll causing urinary tract infections. Infect. Immun. 31: $564-570$.

56. Kallenlus, G., R. Mollby, S.B. Svenson, J. Winberg, and H. Hultberg. (1980) Identiffcation of a carbohydrate receptor recognlzed by uropathogenic Eschertchia coll. Infection 8: 228-293.

57. Leffler, H., and C. Svanborg-Edén. (1980) Chemilcal identiflcation of a glycosphingolipld receptor for Escherichia coli attaching to human urlnary tract epithelial cells and agglutinating erythrocytes. FGMS Microbiol. Lett. 8: 127-134.

58. Valsinen, V., T.K. Korhonen, M. Jokinen, C.G. Gahmberg, and C. Ehnholm. (1982) Blood group $M$ speciflc haemagglutinin in pyelonephritogenic Escherichia coli. Lancet 1 : 1192.

59. Korhonen, T.K., V. Vaisänen-Rhen, M. Rhen, A. Porc, J. Parkkinen, and J. Finne. (1984) Escherichla coll fimbriae recognizing sialyl galactosides. J. Bacter101. 159: 762-766.

60. Kä11entus, G., R. Mol1by, S.B. Svenson, L. Helin, H. Hultberg, B. Cedergren, and J. Winberg. (1981) Occurence of P-fimbriated Escherichia col1 In urinary tract infections. Lancet 11: 1369-1372.

61. Valsanen, V., J. Elo, L.G. Taligren, A. Siltonen, P.H. Mäkela, C. Svanborg-Edên, G. Källenius, S.B. Svenson, H. Hultberg, and T. Korhonen . (1981) Mannose-resistant haemagglutination and $\mathrm{P}$ antigen recognition are characteristic of Escherichia coli causing primary pyelonephritis. Lancet ii: 1366-1369.

62. Svanborg-Edén, C., L. Hagberg, L.A. Hanson, T. Korhonen, H. Leffler, and 5. olling. (1981). Adhesion of Escherlchia coli in urinary tract infection. In: K. EL1Lot, M. O'Comnor, and J. Whelan (Eds). Adhesion and mlcroorganism pathogenicity. Ciba Foundation Symposium 80 Pitman Medical, Iunbridge Welis.

63. Leffler, H., and C. Svanborg-Edén.(1981) Glycollpid receptors for uropathogentic Escherichla coll on human erythrocytes and uroepithellal cells. Infect. Immun. 34: 920-929.

64. Lomberg, H., L.A. Hanson, B. Jacabsson, U. Jodal, U. Leffler, and C. Svanborg-tdén. (1983) Correlation of p-blood group, vestcourethral reflux and bacterial attachment in patients with recurrent pyelonephritis. N. Eng1. J. Med. 308: 1189-1192. 
65. Jann, K., B. Jann, and G. Schmidt. (1981) SDS polyacrylamide gel electrophoresis and serological analysis of pili from Eschericha coli of different pathogenic origin. FEMs Microbiol. Lett. $11: 21-25$.

66. Orskov, I., and F. Drskow. (1983) The serology of Escherlchia coll fimbriae. Prog. Allergy 33: 80-105.

67. Parry, S.H., S.N. Abraham, and M. Sussman. (1982) The biological and serological properties of adhesion determinants of Escherichla coli isolated from urinary tract infection. In: $H$. Schulte-Wisserman (ed. .) clinical, bacteriological and immunological aspects of urinary tract infections in children. Georg Thieme Verlag, Stuttgart. 


\section{MOLELULAR CLONING AND CHARACTERTZATION OE PS RMBRIAE FROH A UROPATHOGENIC ESCHERICHIA COLI}

\section{SUMMARY}

The genes responsible for the formation of F9 fimbriae of the uropathogenic Escherichia coll strain C1018 were cloned by a cosmid cloning procedure. A positive clone was further subcloned by removing two BamHI fragments and the remaining plasmid pPIL288-10 had a size of $25 \mathrm{~kb}$. This clone still produced fimbriae as judged by electron microscopy and mannose-resistant havemagglutination (MRHA). Antisera were raised against the clone and against fimbriae purified from the clone. The first antiserum was used in a Western blot to prove the purity of the $F 9$ fimbriae. The antiserum raised against purified fimbriae was used in inhibition tests of MRHA and adherence of cloned bacteria to human uroepithelial cells.

\section{INTRODUCTION}

E. coli is the most conmon infecting organism in urinary tract infection. A variety of bacterial factors, e.g. haemolysin production, possession of Colv plasmids, $O$ and $K$ antigens, serum resistance and adhesion properties maty influence the virulence of uropathogenic E. coll strains [1-7].

The achesion properties are mediated by fimbriae, which can be distinguished into type 1 fimbriae that cause mannose-sensitive haemagglutination (MSHA) of guinea pig erythrocytes, and fimbriae that cause MRHA of erythrocytes of human and various animal sources. The MRHA fimbriae can be subdivided on the basis of their receptor specificity [8-10]. Among the MRHA fumbriae the $P$ fimbriae have especially been associated with the pathogenesis of pyelonephritis [11].

Orskow and Orskow [12] described different MRHA antigens from uropathogenic $E$. coli. They suggested to use the term $F$ antigens for fimbrial antigens and they described at least eight serologically different types. Parry et al. [13] could detect seven distinct antigenic determinants which have been designated a-g. In most cases fimbrial antigens from enterotoxigenic $E$, coli $(\mathrm{K} 88, \mathrm{~K} 99, \mathrm{CFA}$ I and CFA II) are genetically determined by plasmids [14] in contrast with fimbrial antigens from uropathogenic $E$. coli which are chromosomally determined $[15-18]$. Until now there are four 
reports about the cloning of chromosomally encoded fimbrial antigens from uropathogenic E. coli strains. The pop pill $[16,19]$ and the fimbriae cloned by Clegg [15,20]: though serologically not determined, are not cross-reactive [15]. The first report on the cloning of fimbriae genes from an uropathogenic $E$ coli strain with well characierized fimbriall constitution was described by Van Die at al. [18]. They described the molecular cloning of $\mathrm{FT}_{2}$ firmbriae from the uropathogenic $E$. coll strain ADI10. The finnbriae cloned by Rhen et al. maly be identical with the fimbriae from strain AD110 [17].

This report describes the molecular cloning of the F9 fimbriae from $E$ coli CI018. The F9 term was originally given to the fimbrial antigens of a strain examined by Korhonen et al. [21]. In this. study we used the strain $\mathrm{C} 1018$ which is the reference strain for F9 as determined by Orskov and Orskov [12].

\section{MATERIALS AND METHODS}

\subsection{Bacterial strains, plasmids and growith media}

E. coli strain $\mathrm{ClO18}(\mathrm{O} 2: \mathrm{K} 5: \mathrm{H} 4)$ was obtained from F. and I. Orskow (Statens Serum Institut, Copenhagen). This strain giwes rise to MRHA and expresses F9 fimbriae [12]. These fimbriae were determined as P fimbriae by S.B. Svenson and $G$. Kallenius (The National Bacteriological Laboratory, Stockholm, Sweden). JA221 is a recA hsdA deriwative of the $E$. coli $K-12$ strain $C 600$ [22]. AM1727 is a recA deriwative of JE2571, an $E$. coli $\mathrm{K}-12$ strain deficient in the production of lype 1 limbriae [18]. Plasmid vectors used were pJB8 [23]. PBR322 [24] and pACYC184 [25].

Bacteria were cultivated in L-broth or on Brain Heart Infusion agar (Oxoid). Selective pressure against loss of plasmids was imposed by adding 50 $\mu \mathrm{g} / \mathrm{ml}$ ampicillin or $100 \mu \mathrm{g} / \mathrm{ml}$ chloramphenicol to the mediat.

\subsection{Recombinant DNA sechniques and enzymes}

Cosmid cloning procedure was carried out exactly as described by Van Die et al. [18]. Restriction endonucleases and ligase were obtained from Boehringer. Incubation conditions were according to the instruction of the manufationer.

Plasmid DNA was isolated as described by Birnboim and Doly [26]. Transformation was carried out according to the method of Kushner [27].

\subsection{Electron microscopy, heanagghturination assays and adherence to human uroepithelial cells}

Adherence to human uroepithelial cells and electron microscopy was carried out as described by Van den Bosch et al. [5]. Haemagglutination activity of human erythrocytes was determined by the method of Van den Bosch et all. [7].

\subsection{Purification of fimbriae}

Fimbriae were purified essentially according to the method described by Korhorven et al. [28]. After mechanical detachment from the bacterial cells the fimbriae were precipitated with ammonium sulfate, dialyzed, and solubilized in buffer containing deoxycholate. This fraction was concentrated in an Amicon ultrafiltration cell until a protein concentration of approx. $8 \mathrm{mg} / \mathrm{ml}$.

This fimbrial solution was further purified by two sequential sucrose gradients. When the purified fimbriae contained other proteins ts judged by SDS-PAGE [29] or Western blotting, the fimbriat were purified once again on a sucrose gradient. The fimbriae concentration was measured by the method of Lowry et al. [30],

\subsection{Antisera and Western blots}

During this study we used two antisera. Antiserum raised in rabbits against liwe $E$. coli AM1727 harboring PPIL 288-1 was used to prove the purity of fimbriae in Western blots. A second antiserum was raised against purified fimbrine. Absorbtion was carried out with AM1727. Western blots were carried out by the method of Muilerman et al. [31].

\subsection{Cell exatrats}

Bacteria were grown on 10 Brain Heart Infusion agar plates for $16 \mathrm{~h}$ at $37^{\circ} \mathrm{C}$. Cells were harvested and suspended in $10 \mathrm{ml}$ PBS-formalin $0.25 \%$. Subsequently, the cells were sonicated until the absorbance at 600 nm was reduced 10 times. This sonicated extract was centrifuged for $15 \mathrm{~min}$ at $15000 \mathrm{rew} / \mathrm{min}$. Supernatant was used as a total protein fraction in Western blots. 


\section{RESULTS}

4.1. Cloning of genetic determinants encoding for MR fimbriae

Chromosomal DNA of E. coll C1018 was partially digested with the restriction endonuclease Sau3A. Fragments of $30-45 \mathrm{~kb}$, obtained by centrifugation through a $1.25-5 \mathrm{M} \mathrm{NaCl}$ gradient, were ligated into the single BamHII site of the cosmid pJB8. Recombinant cosmid molecules were packaged into phage $\lambda$ particles and transduced into the $E$ coli K12 strain JA221, Of 800 trans ductants tested, 8 exhibited the MRHA reaction. The clone with the strongest MRHA was analyzed further; it possessed a plasmid (designated pPIL288-1) of the expected size (approx. $45 \mathrm{~kb}$ ).

\section{Subcloning of fimbrial genes}

Digestion of pPIL288-1 with the restriction enzyme Bam HI revealed three recognition sites for this enzyme. After digestion of PPIL288-1 with Bam HI and ligation followed by transformation to E. coll $\mathrm{K}-12$ strain JA221, the transformants were tested for MRHA activity.

Three transformants with MRHA activity possessed a plasmid (pPIL288-10), which had deleted two BamHIl Iragments and had an estimated size of $24 \mathrm{~kb}$. A physical map of PPIL288-10 was determined from digestions and suitable double digestions with several restriction enzymes (Fig. 1a). Subsequently, plasmid pPIL288-10 was digested with restriction endonuclease Sall, and the resulting $16.1-\mathrm{kb}$ fragment (Fig. 1b) was ligated into the Sall site of PACYC184 (pPIL288-11) and into the Sall site of pBR322 (pPIL288-12). All clones were transformed to E. coli $\mathrm{K}-12$ strain $J A 21$ and AM1727 and were still coding for MRHA. Furthermore, fimbria production of clones in AM1727 was checked by electron microscopy and all clones produced large anounts of fimbriae (Fig. 2).

\subsection{Characterization of $F 9$ fimbriae}

Native fimbrias were purified from strain AM1727 harbouring pPIL288-10 as described in MATERIals AND methons. Purity of this fimbria preparation was checked on SDS-PAGE (Fig. 3) and the $M_{\mathrm{r}}$ was determined to be 21000 . Purity
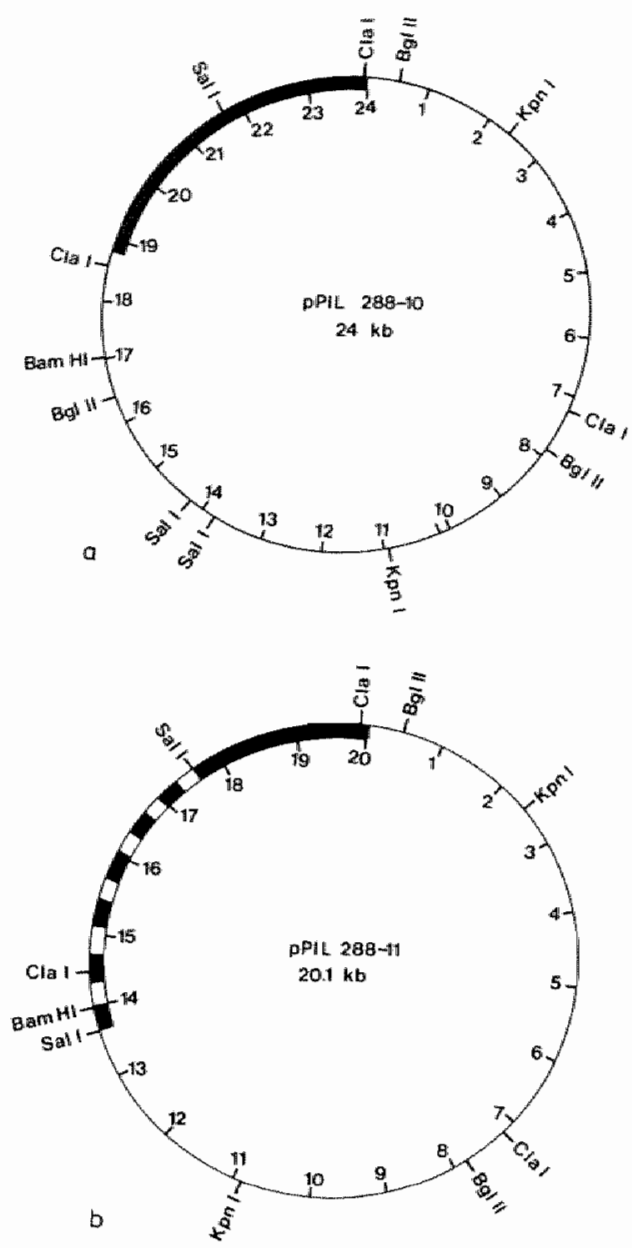

Fig. 1. (a) Restriction map of pPLL2g8-10. The solid black time represents the vector pJ B8. (b) Restrietion map of pPLL2 288.11. The solid black lina represents a part of the vector $p J B d$ and the black and white line represents the wector pACYCL84

was also checked by Western blotting (Fig. 4, lane b) with an antiserum raised against whole bacteria (AM1727, harbouring pPIL288-1). Both methods, SDS-PAGE and Western blotting, did not reveal any other proteins than the fimbriae. 
The anount of rimbriae produced by the different clones and the parental strain was measured by an HA activity test as described in Matratals AND METHODS. All clones gave rise to higher MRHA titers than the parental strain, suggesting that these clones produced more fimbriae than the parental strain (Table 1). This was also shown by electron microscopy where the amount of fimbriae from cloned strains was much higher than the parenual strair. (Fig. 2).
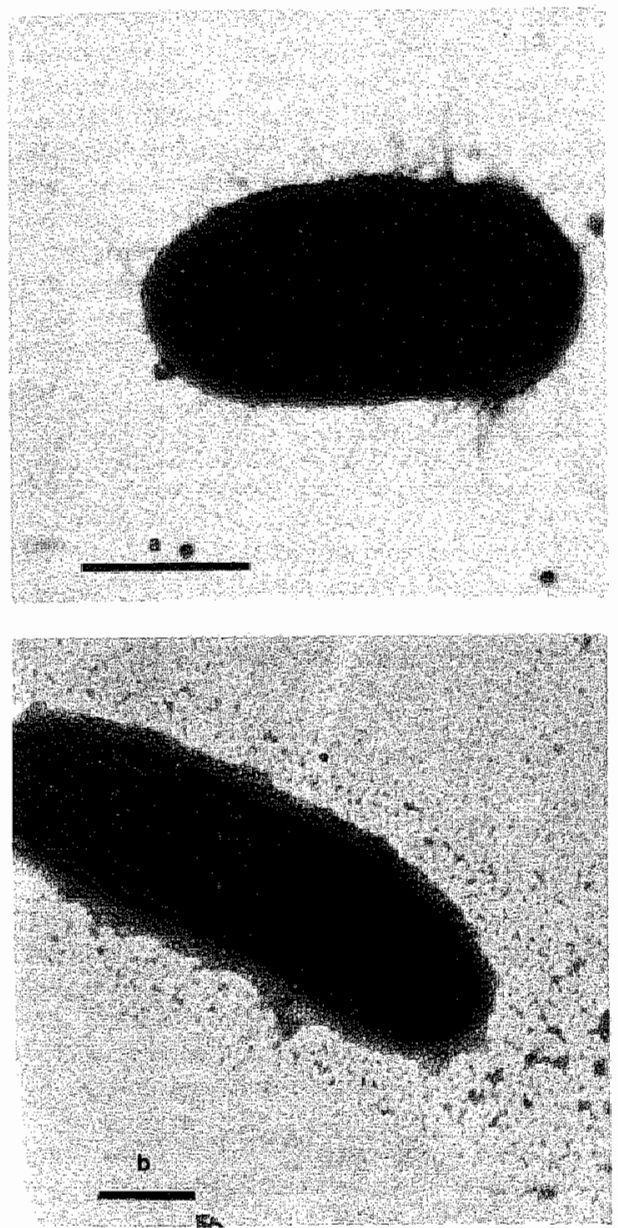

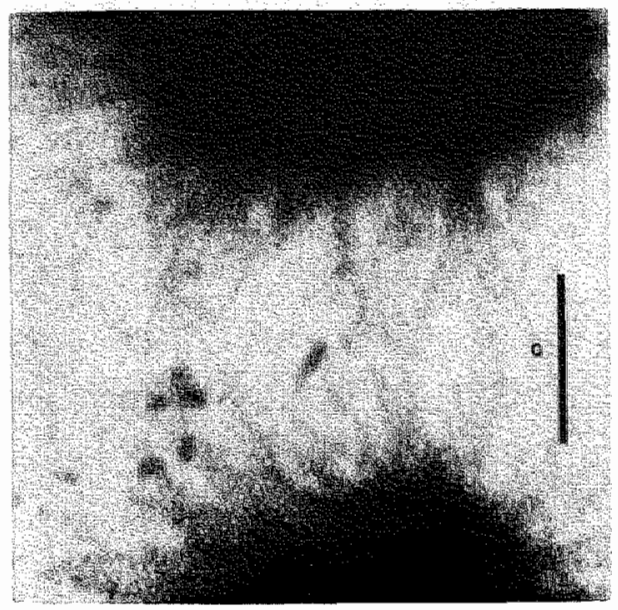

Fig. 2. Electron micrographs of purental and cloned straial. (a) C1018: (b) AM172\%; (c) AM1727 harbouring pPlL288-10, The bar represents $500 \mathrm{~nm}$.

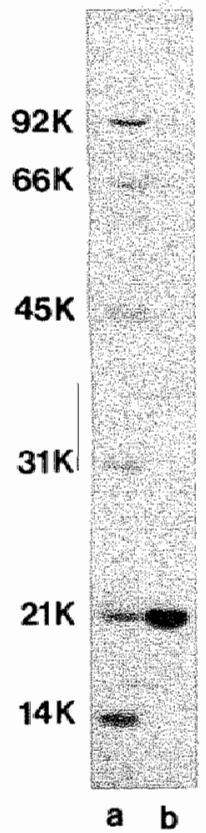

Fug. 3. SDS-PAGE of marker proteins (fane a) ant putified fimbriate from strain AM1727 harbou ring PPIL288-100 (Iane b). 


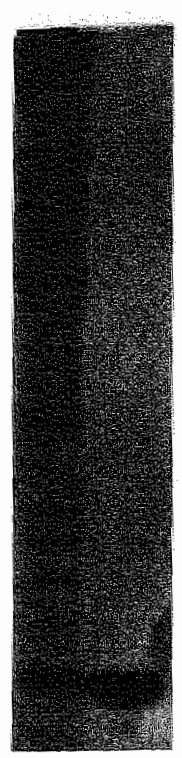

a

b

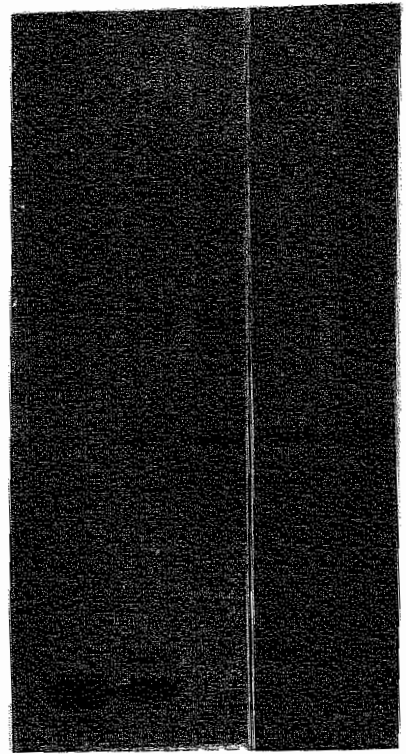

9

Fig. 4. Westerta blowing of a crute acell extract from the parental strain Clot (lane a), purified for fimbriate (lanes b, c), a crude cenl extract of AM1727 harbouring pPIL 288-10 (1anes

Adherence of cloned and parental strains to human uroepithelial cells was tested as described in MATERIALS AND METHODS. The parental strain and the strains with cloned fimbriae showed MR adherence to human uroepithellal cells in contrats: with strain AM1727 (Table 1). Strains with cloned fimbriae showed an even higher MR adherence than the parental strain. After preincubation of the bacteria with absorbed antiserum raised atgainst purified fimbriae the MRHA and the MR adherence were totally inhibited (Table 1). In these inhibition experiments antiserum concentrations were used which did not cause agglutination of the bacteria as checked by microscopy. The same antiserum was checked in a Western blot (Fig. 4, lanes $c-e)$ and reacted faintly with two proteins and strongly with the fimbriae of a crude protein fraco tion. The faint reaction with the two proteins was caused by the goat anti-rabbit horse radish peroxidase conjugate which reacted aspecific with these proteins. This suggests that this antiserum

d. f) and a crude cell extract of AM1727 (lanes e. gl. Lanes a-b were incubated with antisenum raised against $\mathrm{AM} 1727 \mathrm{hag}$ bouring PPIL 288-1; llanes: c-e willy absorbed antiserum raised against purifted fimbriae and lanes $\mathrm{t}-\mathrm{g}$ with goat anti-rabbit horse radish peroxidase conjugate only.

Tabile I

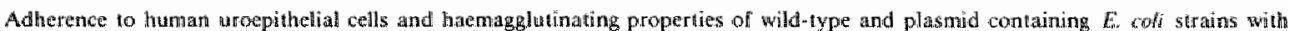
human erythrocytes

\begin{tabular}{|c|c|c|c|c|c|}
\hline \multirow[t]{3}{*}{ Stratin } & \multicolumn{3}{|c|}{ Hawemaglutination titer } & \multirow{2}{*}{\multicolumn{2}{|c|}{$\begin{array}{l}\text { Adlherence to } \\
\text { uroepitheliat cells }\end{array}$}} \\
\hline & \multirow{2}{*}{$\begin{array}{l}\text { Without } \\
\text { manose }\end{array}$} & \multirow{2}{*}{$\begin{array}{l}\text { With } \\
\text { mannosa }\end{array}$} & \multirow{2}{*}{$\begin{array}{l}\text { In the } \\
\text { preseruce of } \\
\text { antiserums }\end{array}$} & & \\
\hline & & & & - & $\begin{array}{l}\text { In the } \\
\text { presence of } \\
\text { antilserum }\end{array}$ \\
\hline- & & & & 34 & $\cdots$ \\
\hline $\mathrm{C} 1018$ & 16 & 16 & 2 & 49 & 18 \\
\hline AMI1727 & 0 & 0 & - & 13 & - \\
\hline AM1727 pPIL288-1 & 128 & 128 & 0 & - & - \\
\hline AM11.727 pPLL288.10 & 256 & 256 & 2 & 39 & 12 \\
\hline AM1727 pPIL281-11 & 128 & 128 & 0 & 77 & 9 \\
\hline AM1727pHIL288-12 & 128 & 128 & 0 & 74 & 11: \\
\hline AMO727 pJB8 & 0 & 0 & - & - & - \\
\hline AML727 pACYCI84 & 0 & 0 & - & - & - \\
\hline
\end{tabular}

\footnotetext{
- Antiserum was raised in rubbits against puritied fintorat and absorption was carried out with AM1727.

"Adherence was tested in the presence of mannose, examined with a light microscope at $400 \times$ magnification, and expressed as the percentsge of epithehal cells with nore than 25 adherent bacteria out of a total of 200 cels counted.
} 
reacted only with F9 fimbriae from a crude protein fraction of AM1727 harbouring PPIL 288-10. A third, yet unidentified, faint protein band ap" peared in the AM1727 harbouring pPIL288-10 (Fig. 4, lane d) compared with the AM1727 (Fig. 4. lane e), also present in the conjugate control (Fig. 4, lane 0 .

\section{DISCUSSION}

This studly describes the molecular cloning of the genes encoding for $\mathbf{F} 9$ fumbriae. Cloning of fimbriae genes has many advantages: (1) one cran distinguish between different fimbriae produced by one strain; (2) the organization of the genes involved in biogenesis of fimbriae can be studied; (3) fumbriae genes cloned in a high-copy plasmid give rise to a huge fimbria production which facilitates the purification of fimbriae; (4) strains that differ in only the type of fimbriae expressed, will be useful in a detailed serological study.

After cosmid cloning and subcloning in the pACYC184 vector and the $\mathrm{pBR} 322$ vector a chromosomal DNA fragment of $13.6 \mathrm{~kb}$ was found which still encoded for F9 fimbriae and MRHA. From comparison with other cloned fimbrial gene clusters it can be expected that the exact region encoding for these fimbriae is still smaller. The pap pili operon described by Normark et al. [19] is encoded by a $8.2-\mathrm{kb}$ fragment. Clegg and Pierce [20] described a region of $5.4 \mathrm{~kb}$ which encoded fimbriae and Van Die et al. $[18,32 \rrbracket$ described a region of approx. $10 \mathrm{~kb}$ which encoded for $\mathrm{F}_{2}$ fimbriae. To extablish the exact size of this DNA fragment necessary for fimbrial production and the genes involved in the expression of $F 9$ fimbriae we will mapp the genes with transposable elements.

Fimbriae were purified from AM1727 harbouring PPIL288-10 by the method of Korhonen et all. [28] with omitting the last step, a Sepharose $4 B$ column in $6 \mathrm{M}$ urea buffer. We found this last step, included for purification of fimbriae from flagella material, not necessary, especially when $E$. coll K-12 strains were used as starting material.

The fimbriae were shown to be pure in SDSPAGE and Western blotting (Figs. 3 and 4, lane b).
The $M_{\text {s }}$ was found to be 21000 , still in the range of 15000-29000 as is described for fimbriae [14].

E. coli K-12 strains with plasmids coding for cloned fimbriae had a much higher production of fimbriae than the parental strain as determined by electron microscopy, MRHA titers and adherence (Table 1, Fig. 2). Purification of limbriae from cloned strains gave a higher yield than from the parental strain (not shown).

By Western blot analysis it could also be shown that purified fimbriate from AM1727 harbouring pPIL288-10 exhibited the same $M_{r}$ and antigenicity as fimbriae from the parental strain C 1018 (Fig. 4, lane a and b).

Normark et al. [19] stated that the fimbrial subunit of the pap pili is not the actual adhesin. Whether or not the F9 fimbrial subunit is the adhesin cannot be proven until we have mapped the genes codling for F9 fimbriae with transposons. However, our results strongly suggests that for $F 9$ fimbriae the fimbrial subunit is the adhesive factor because adhesion and HA of parental and $E$. coli K-12 with cloned fimbriae were strongly inhibited by adding the absorbed antiserum raised against purified $\mathrm{Fg}$ fimbriae. This antiserum reacted only with F9 fimbrial subunit as detected in a Western blot (Fig, 4, lanes c-g). This could mean that for F9 fimbriae the fimbrial subunit is also the adhesive factor, but this has to be prowen by further genetic research.

\section{ACKNOWLEDGEMENTS}

This work was supported by the Dutch Kidney Foundation (Grant No. 81320), We are grateful to H.A. Valkenburg (Erasmus University, Rotterdam) and P.A.M. Guinee (State Institute for Public Health, Bilthowen) for support and advice.

\section{REFERENCES}

11/ Evans, D.J., Evans, D.G., Hohne, C., Noble, M.H. Haldane E.V., Lior, H. and Youmg, L.S. (1981) J. Clin. Microbicl. 13,171-178.

[2| Hughes, C. Phaillips, R. and Roberts, A.R. (1982) Intect. Irmmun. $35,270-275$. 


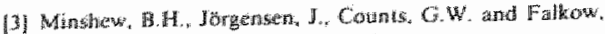

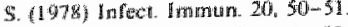

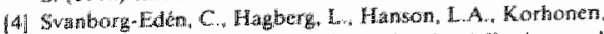

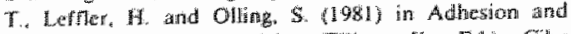

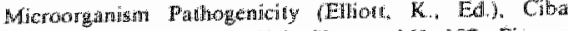

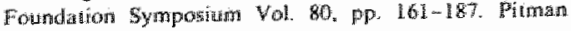
Medical Lontidon.

[5] Van den Bewch, J F, Verborm-Solmer, U. Postma, P. De

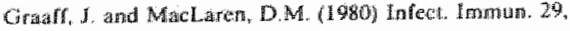
$236-233$.

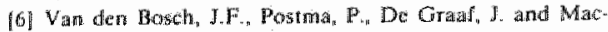

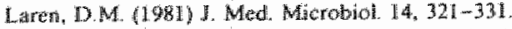

[7) Van den Boseh. JF, Posma, P. Koopman, P.A.R. De

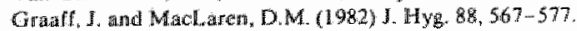

(8) Kallenius, G. Swensison, S. B. MBiby, R., Cedergren. B.,

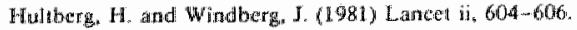

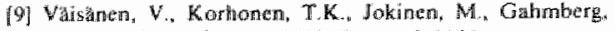
C.G. altid Ehaholur, (. (1982) Laned i, 1192.

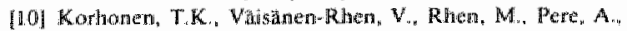

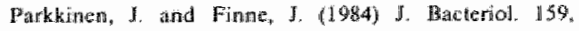
$762-766$

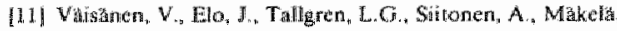

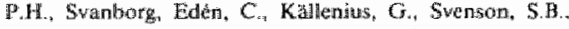
Hulterg, $H$. and Korlonen, T.K. (1981) Iancel ij, $1368-1369$.

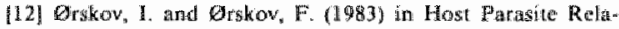
tionships in Gram-negatiwe Infections. Progress in Allergy (Hanson, L. Kallos, P. and Westphath O. Eds.) Vol. 33, pp. B0-10s. Karger, Biasel.

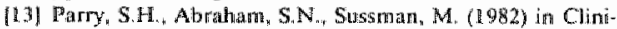
cais Bacteriological and Irnmunologicat mspects of Urinary Tract Infections in Children (Schulte-Wisserman, $H_{\text {, }}$ Ed.) Pp. 113-126. Thicme, Stungart,

[14] Gatatra, W, ald De Graat, F.K. (1982) Microbiol. Kev. $46,129-16 \mathrm{~d}$

115) Clegg, S. (1982) Infect. Immun, 38, 739-744

[16] Hull, R, A., Gill, R.E, Hsu, P., Minshew, B. I. and Falkow, S. $(1,981)$ Infect. Imonum. $33,933-938$.
117) Bhen. M. Knowks, I. Pentitia, M.E. Sarvas, M. authd Korhonetr. T.K (1983) FEMS Microbiol. Let. 19. 1.196123

(18 Van Die, I, Van den Hondel, C., Hamsta, H. Moekstra, W. aryd Bergnans. H. (1983) FEMS Microbiol Lev. 19. $77-82$

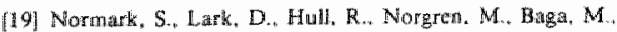

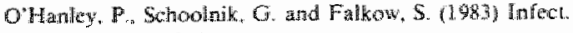

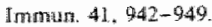

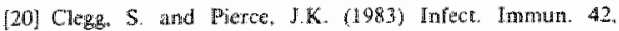
$900-906$.

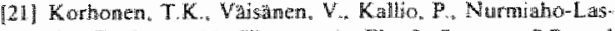

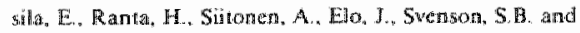
Swanborg Eaten, C. (1982) Scand I. Infect. Dis. Suppl. 33, $26-31$.

122] Clarke, Lu, and Carbon, I. (1975) J. Mol Biol. 120, 517-572.

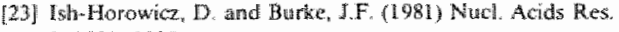
$9,2989-2998$.

24 Boliwar, F. Rodriguter, R. L., Coreene, P.J., Beflach, M.C. Heyneker, H.L. Boyer, H.W. Crosa, J.H and Fallow, S. (1977) Gene $2,95-113$.

[25] Chang, A.C.Y and Cohen SN (1978) J Bacteriol 134, $1141-1156$.

[26] Biruboirn, H.C and Doly, I. (1979) Nucl. Acids Res. ?. $1513-1523$.

(27) Kushner, 5 R, (1978) in Genedic Fngunesing (Boyer, H.W and Nideosia. S., Eds.j, pp. 17-23. Elsevier, Amsterdam.

[28) Korhonew, $T K$, Nuraiaho, E. Ranta, H. and Svamborg Eden, C. (1980) Infect. Immun 27,569m575.

129] Luquenterg, B. Kojers, 1., Peters, R. Van den Hoek, P. and Voun Alphen "L. (1975) PEBS Lett 58, 254-258.

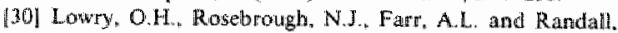
[R.J. (1951) J. Biol. Chem: 193, 265-275.

(31) Muileman, H.G. Ter Hart H.G.J. and Van Digk, W. (1982) Anal. Biochen $170,46-51$.

132) Vam Die, I, Van Megic I. Hoekstra, W. and Bergmans, H. (1984) Mol, Gen. Genet. 194, 528-533. 
MOLECULAR CLONING OP F11 FIMBRIAE FROM A WROPATHOGEHC ESCHERTCHIA COLI AND CHARACTERIZATION OF FIMBRIAE WTHY POLYCLONAL AND MONOCLONAL ANTTBODIES

\section{SUMMARY}

The genes coding for F11 fimbriae from the uropathogenic Escherichia coli $\mathrm{C} 1976$ were cloned by a cosmid cloning procedure. Two cosmid clones expressed F11 timbriae and these clones possessed. an identical DNA fragment of $8.9 \mathrm{~kb}$. This fragment was subcloned into pBR322 and this plasmid still produced fimbriae and caused a mannose-resistant haemagglutination (MRHA). Polyclonal and monoclonal antibodies were produced against purified cloned Fl1 fimbriae. Both types of antibodies were used in inhibition tests of MRHA and acherence of bacteria to the uroepithelial cell line T24. After preincubation of bacteria with pollyclonal antiserum the MRHA and the MR adherence were totally inhibited. Preincubation of bacteria with monoclonal antibodies did not inhibit MRHA and MR adherence.

\section{INTRODUCTION}

E. coli is the most common infecting organism in urinary tract infection. An important virulence factor is the adhesive capacity of $E$. coll to uroe- pithelial cells, mediated by bacterial fimbriae $[1-3]$. Adhesins of $E$. coli an be divided into type 1 fimbriae that cause a mannose-sensitive haemagglutination (MSHA) of guinea pig erythrocytes and fimbriae that cause an MRHA of human erythrocytes. These MRHA fimbriae can be subdivided into $P, M$ and $S$ fimbriae on the basis of their receptor specificity [4-6]. $\mathrm{P}$ fimbriate especially have been associated with the pathogenesis of pyelonephritis [7], and it has been shown that these $\mathrm{P}$ fimbriae recognize the disaccharide $\alpha$-DGal $p-(1-4) \beta-\mathrm{D}-\mathrm{Gal} p$ as a receptor on uroepithelial cells [8]. Ørskov and Orskov [9] and Parry et al. [10] described several serologically different types of fimbriae from uropathogenic $E$. coli. Orskov and Orskov [9] introduced the term $\mathbb{E}$ fimbriae and numbered the various MRHA fimbriae types from uropathogenic E. coli strains F7 till F1.2. Recently, the molecular cloning of Fi, (Van Die el al., manuscript in preparation), $F 7_{2}[11]$ and $\mathrm{F} 9$ [112] were described. In this report we describe the molecular cloning and characterization of F11 fimbriae from the uropathogenic $E$. coli C1976.

\section{MATERIALS AND METHODS}

\subsection{Bacterial strains, plasmids and growrh media}

The clinical isolate used in this study, $E$. coll 
sirain $\mathrm{C} 1976(\mathrm{O}) \mathrm{K} 1: \mathrm{H})$, was ohtaned from $\mathbb{1}$. and F. Orskow (Shatens Serum Instütu Copenhageno, gives rise to MRHA and expresses Fl1 fimbrial [9]. These fimbriae were determined 2.s. P limbriae by $\$$. B. Svenson and C. Kallenius (The National Bacteriological Laboratory. Stockholm).

AM1727 is a recA derivative of JE2571, an $E$. coll $\mathrm{K}-12$ strain which does not produce type fimbriae [11]. IA221 is a recA hrdA derivative of the $E$. colf $\mathrm{K}-12$ strain $C 600$ [13]. Plasmid vectors used were pBR322 [14] and PACYC184 [15]. The cosmind vector pJC74 was kindly prowided by Jorg Halicker Institut for Genetik und Mickrobiologie, Würburg).

Bacteria were cultivated in Brain Heart Infusion broth (Difco) or on Brain Heart Infusion agar (Oxoid). Selective pressure against loss of plisimids was imposed by adding $50 \mu \mathrm{g} / \mathrm{ml}$ ampicillin or $100 \mu \mathrm{g} / \mathrm{ml}$ chloramphericol to the media.

\subsection{Recombinant DNA techriques and enzymes}

Cosmid vector $\mathrm{pJC74}$ was totally digested with BawHII and treated with alkaline phosphatase.

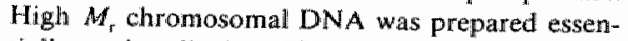
tially as described by Hull et al. [16] and ireated with Sam $3 \mathrm{~A}$. Fragiments of $30-45 \mathrm{~kb}$ were higated into the cosmid wector, packaged into $\lambda$ phage particles and transduced to strain $E$ coli $K-12$ JA221. as described by van Die et all. [11].

Restriction endonuclease, ligase and alkaline phosphatase were obtained from Boehringer. All enzymes were used as suggested by the manufacturer.

Plasmid DNA was isolated as described by Birnboim and Doly [17]. Transformation was carried out according to the method of Kushner [18].

\section{3. Electron microsicopy and haemaggiturination asi-
says}

Electron microscopy was carried out as described by Van den Bosch et al. [2]. For determination of the MRHA activity of strains, serial dilutions of bacteria were incubated with human erythrocyles and incubated for $2 \mathrm{~h}$ on ice; HA was read after agitation [3].

Inhibition of HA by antibodies was tested with bacteria which were preincubated for 30 min at room temperature with polyclonal antiserum monoclonal antibodies. Polyclonal and mc clonal antibodies were used at concentrati which did not cause aggitutination of bacteria checked by microscopy.

3. Adherence to human wropithelial cell fine :

The human uroepithelial cell line $\mathrm{T} 24$ was kin supplied by Bøörn Lumd (Department of Micro ollogy, Umea, Sweden). Adherence experime were carried out essentially as described by Lund et al (personal communication). Briefly, I cells were grown in MEM (Gibco) supplement with $1 \%$ L-glutamine (Flow) and $10 \%$ fetal $c$ serum (Flow). Cells were seeded at low dens: (1000 cells $/ \mathrm{cm}^{2}$ ) in 6-well chusters (Cositar) al allowed to spread for $24 \mathrm{~h}$ in a $5 \% \mathrm{CO}_{2}$ atm sphere. After washing twice with MEM witho serum the cells were incubated with $2 \times 11$ bacteria per well for 1 h at $37^{\circ} \mathrm{C}$. After th incubation $\mathrm{T} 24$ cells were washed with saline $(5 \times$ and stained with $30 \mathrm{~g}$ filtered Giemsa sta (Giemsas-Lósurig: Merck). Adherence was e annined with a light microscope and expressed the 9 of 124 cells with at least 25 adherent bacter out of a total of 100 cells counted.

\subsection{Purification of fimbriae preparation of ce exrracts, SDS-PAGE and Western blots}

Fimbriate were purified essentially according t the method described by Kortunen et al. 19 avoiding protein-denaturing conclitions [12]. Cel extracts were prepared by sonication as describer previously [12]. Protein concentrations were mea suted by the method of Lowry et al. [20]. Purity of fimbriae preparations was checked by SDS-PACE [21] and Western blots [22].

\subsection{Polyclonal and monaclondal com tisera}

Polyclonal antisera were raised in rabbits against purified cloned F11 fimbriae and against live AM11727 harbouring pPIL291-15.

The production of the monoclonal antibodies M7 4 and M7-5, recognizing different epitopes on Fll fimbriae, will be described elsewhere. (J.M. de Ree, P. Schwillens and J.F, van den Bosch. Monoclonal antibodies that recognize the $\mathrm{P}$ fimbriae $\mathrm{FT}_{1}, \mathrm{FT}_{2}, \mathrm{Fg}$ and $\mathrm{Fll}$ from uropathogenic $\mathrm{E}$. coli, submitted for publication). 


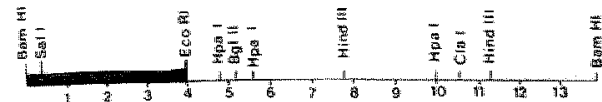

Fig. 1. Restriction map of pPlL 291-15. The solid black line represents the vector pBR322.

\subsection{ELISA with purified FII fimbriae}

An ELISA with purified cloned fimbriae was carried out essentially as described by Dodd and Eisenstein [23]. Microtiter plates (PVC; Flow) were coated with purified F11 fimbriae, followed by incubation with serial dillutions of poly- or monoclonal antibodies. Anti-F11 fimbriae activity was detected colorimetrically after incubation with goat anti-rabbit or goat anti-mouse antiserum, respectively, conjugated with peroxidase (Nordic) and addition of the substrate oxphenylenediamine (Sigma). Absorbance at $495 \mathrm{~nm}$ was determined with a Titertek multiscan ELISA plate reader.

\section{RESULTS}

\subsection{Molecular cloning of the genes coding for FII fimbriae}

After a cosmid cloning procedure as described in MATERIALS AND METHODS the colony bank was screened for MRHA. Two colonies were found which exhibited MRHA and production of fimbriae as shown by electron microscopy (not shown). Both cosmids (designated pPIL291-1 and
pPIL2911-3) were purified by the method of $B$ i. mboim and Doly [17]. From both cosmids at BamHI tragment was cloned into the vector pACYC184. These two subclones designated pPIL291-10 and PPIL291-30) were not identical as shown by restriction enzyme analysis. Howewer. both subclones possessed an identical Bam HI. EcoRI fragment and this fragment was cloned into the vector pBR322. A physical map of this plas. mid (pPIL291-15) was determined from digestions and suitable double digestions with several restriction enzymes (Fig. 1). After transformation of pPIL291-15 to E. coll K-12 strain AM1727 this clone still expressed MRHA (Table 1) and fimbriae as checked by electron microscopy (Fig. 2).

\subsection{Characterizarion of Fll fimbriae}

Native F11 fimbriae were purified from strain AM1727 harbouring pPIL291-15 and from the parental strain $\mathrm{C} 1976$. The purity of $\mathrm{F} 1 \mathrm{l}$ limbriae prepared from the clonted strain was checked in a Western blot (Fig. 3, lane c) with an antiserum ratised against AM1727 harbouring pplL291-15. This antiserum reacted strongly with muliple proteins of cell extracts from AM1727 (Fig. 3, lane b) and AM1727 harbouring pPIL291-15 (Fig. 3, lane a), but only with one band in the purified F11 fimbriae preparation (Fig. 3, lane c). Purity of these F11 fimbriae was also shown by SDS-PAGE (Fig. 4). From this SDS-PAGE the $M_{\mathrm{r}}$ was determined to be 18000 . In another Western blot an antiserum raised against purified cloned F11 fimbriae reacted strongly with purified cloned F11

\section{Table}

Adherence of T24 cells and MRHA with human erythrocytes of sild-lype and plasmid-contsining $E$. colf strains, and inhibition by polyclonal and moncolonal antibodies

\begin{tabular}{|c|c|c|c|c|c|c|c|c|c|}
\hline \multirow[t]{3}{*}{$\overline{\text { Straini }}$} & \multicolumn{5}{|c|}{ MRHA titer } & \multicolumn{4}{|c|}{ Adherence to 124 uroeppithel lual cetis it } \\
\hline & \multirow[t]{2}{*}{$\cdots$} & \multicolumn{4}{|c|}{ In the presence of } & \multirow[t]{2}{*}{-} & \multicolumn{3}{|c|}{ In the presence of } \\
\hline & & Polds: & $\mathrm{M}^{7} \mathrm{4}^{\mathrm{h}}$ & $M 7.5^{b}$ & M7.4 and M7.5 & & $\mathrm{PolAs}_{\mathrm{s}}$ & $M 7.4^{b}$ & $M 7 \cdot 5^{h}$ \\
\hline$C 1976$ & 4 & - & 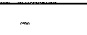 & $\ldots$ & - & 69 & $\ldots$ & - & $\therefore$ \\
\hline AM1727 & 0 & - & - & - & - & 0 & - & - & $m$ \\
\hline AM1727 pPLL291-15 & 128 & $\theta$ & 64 & 128 & 64 & 100 & 6 & 92 & 86 \\
\hline
\end{tabular}

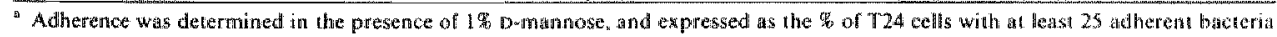
out of a total of 100 cells counted.

"Polyclonal antiserun (PolAs) used and the monoclonal antibodies (M7.4 and M7.5) were raised against purfficd doned Fll fimbriace. 

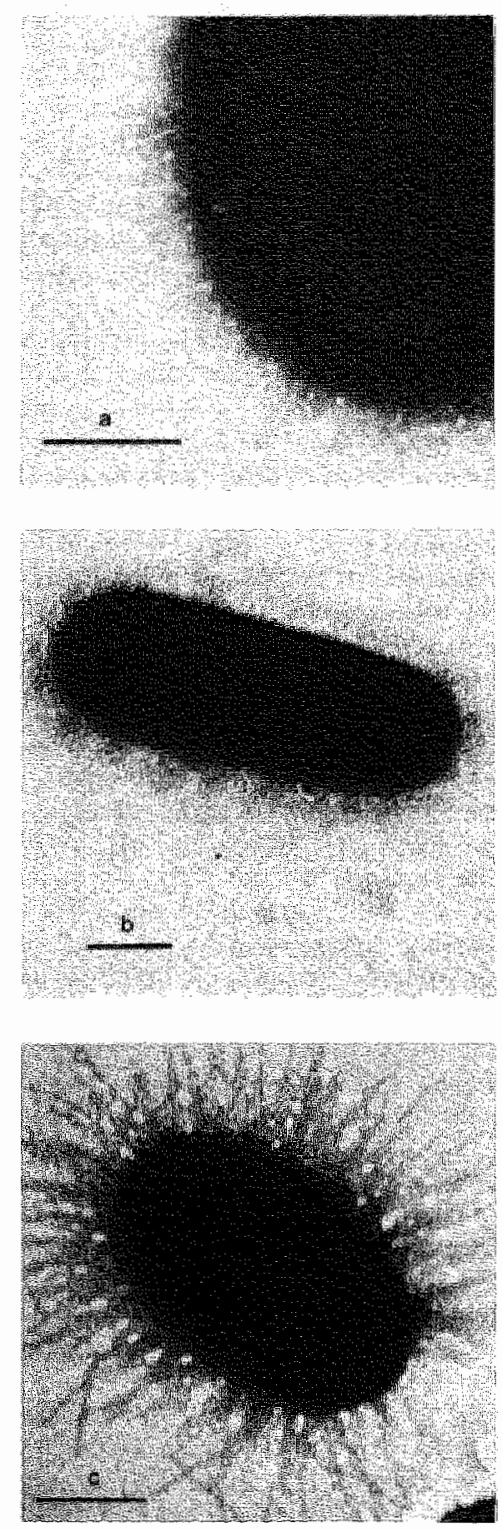

Fig 2. Bectern macrographs of parenual and clowed struin (a) C1976: (b) AM1727: (6) AM1727 hathouring pPIL291-15. The har reprotents $50 \mathrm{nmm}$.
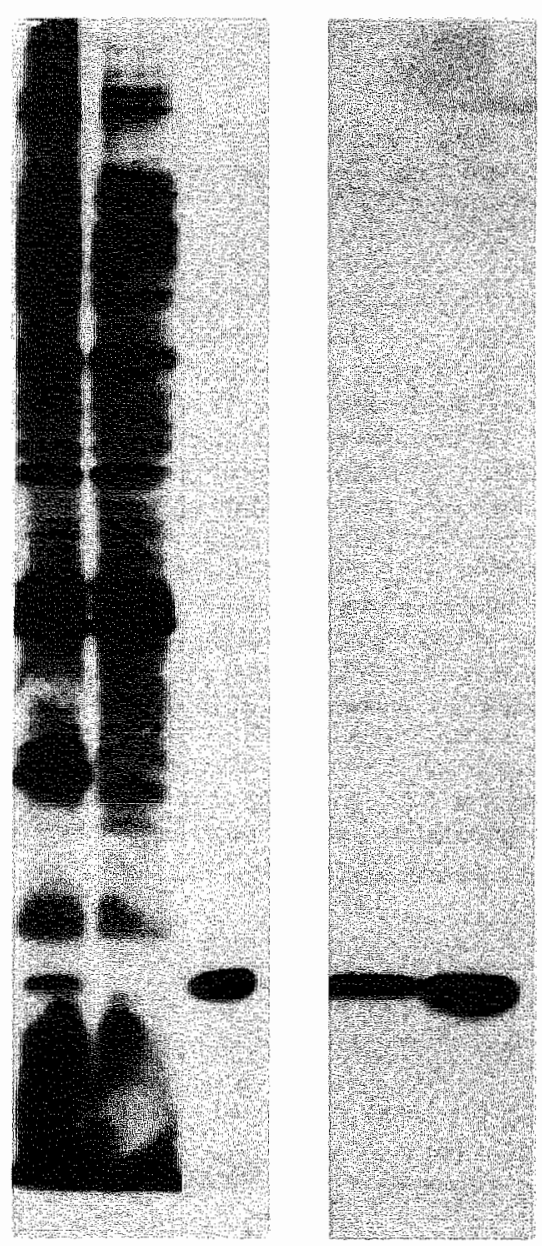

\section{a $\quad b \quad c \quad d \quad e$}

Fig. 3. Western blonting of crude cell extracts from a 41727 (Jan b). AM1727 harbouring pPlL291-15 (lank at. purified choned FII fimbriat (hane and a), and purified parental FII finbriac (lane d). Lants a-o sere incubated with antiserum raised against. A 1727 hatbouring pPLL $21-15$, and lanes o gard e with antisernm against parified F11 fimbriae.

fimbriae (Fig. 3, lane e) and at the same place with F11 fimbriate purfied from the parental strain (Fig. 3, lane d).

In an HA activity lest. it was shown that strain 
AM1727 harbouring pPIL291-15 produced more fimbriate than the parental strain (Table 1). This was also demonstrated by electron microscopy (Fig. 2). The parental as well as the cloned strain showed an MR adherence to the uroepithelial cell line T24, in contrast to strain AM1727 which did not adhere (Table 1). The cloned strain AM1727 harbouring PPIL291-15 adhered stronger than the parental strain C1976, also indicating the huge fimbria production of the clone compared with the parental strain.

Both the polyclonal antiserum and the monoclonal antibodies raised against purified cloned Fll rimbriae reacted strongly with homologous fimbriae in an ELISA. When the titer is defined as the ${ }^{10} \mathrm{log}$ of the last reciprocal dilution with an $A_{490}$ of at least 0.500 , the titer of the polyclonal antiserum was 4.4 , whereas the titers of the monoclonals M7-4 and M7-5 were 4.4 and 4.1 , respectively. In contrast to the polyclonal antisera, which reacted with homologous fimbriae in Western blots (Fig. 3), neither of the monoclonal antibodies showed any reaction in Western blots (not shown). As shown in Table 1, the MRHA as well as the MR adherence to T24 cells of the cloned strain was totally inhibited by preincubation of the bacteria with the polyclonal antiserum. The monoclonal antibodies, however, inhibited neither MRHA nor adherence. Preincubation of the bacteria with both monoclonals at the same time also did not inhibit the MRHA.

\section{DISCUSSION}

In this report we describe the molecular cloning of the genes coding for F1I fimbriae from the parental strain C1976. A piece of $8.9 \mathrm{~kb}$ was responsible for the production of these fimbriae and the restriction map of this pPIL291-15 showed remarkable correspondence with other cloned $\mathrm{P}$ fimbriae $[12,24,25]$.

The higher expression of F11 fimbriae on strain AM1727 harbouring pPIL291-15 (Table 1 and Fig. 2) compared with the parental strain $\mathrm{C} 1976$ was useful for the purification of FII fimbriae Fimbriae isolated from the clone were shown to be pure on SDS-PAGE (Fig. 4) and on Western blots

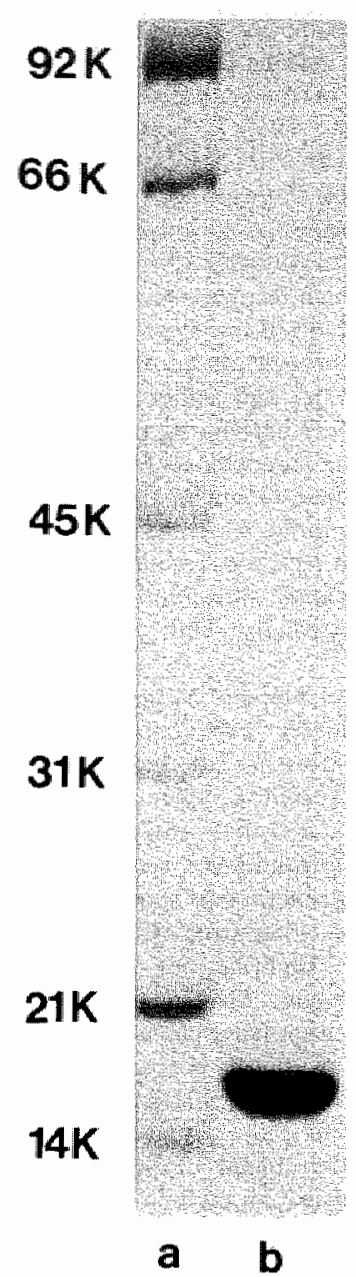

Fig. 4. SDS-PAOE of niarker proteins (lank a) and purrifid fimbriae from strain AM1727 harbotring pPIL 291-15 (lane b).

(Fig. 3, lane c). A polyclional antiserum trised against these purified fimbriate reacted strongly in a Western blot, at the same place with the fimbriac purified from cloned and parental strain (Fig. 3. lane $d$ and ej. From these results we may conclude that we indeed cloned the F11 fimbriae from the parental strain. The HA and adherence assays 
proved that the information for recognizing the receptor structure for $\mathrm{P}$ firnbriate ( $\alpha-\mathrm{D}-\mathrm{G}$ al $p-(1-4)$ $(\beta-\mathrm{D}-\mathrm{Gal} p)$ is present on plasmid pIPLL291-15 (Table 11. When the strain AM1727 harbouring pPLL291-15 was incubated with polyclonal antiserum raised against F1d fimbriae the $H A$ and adherence were totally inhibited (Table 1). This strongly suggested that immunoglobulins are present in this antiserum which recognize that part(s) of the fimbriate that is inwolved in recognizing the receptor structure on erythrocytes and uroepithelial cells. No inhibition of $\mathrm{HA}$ and adherence was. found when strair AM1727 harbouring pPIL29115 was incubated with the monoclonals M7.4 and M7.5. This mears that these monoclonals reacted with epitopes on 511 limbriae which are not involved in recognizing the receptor structure. Nevertheless. both the polyclonal antiserum and the monoclonals reacted strongly with purified fimbriae in an ELISA.

Recently, Lindberg et al. [26] and Norgren et al. [27] found evidence that for pap fimbriae the fimbriae subunits themselves are not responsible for recognizing the receptor structure on uroepithelial cells. They staled that an minor component present in the pap timbriae is responsible for adhesion. Preliminary experiments showed that it was possible to construct clones from pPIL 291-15 which did not produce fimbriae but still agglutinated human eryuhrocytes. This suggests that for litll fimbriae also a minor component may be responsible for recognition of the receptor structure on uroepithelial cells. When indeed a minor component of the fimbriae is the actual adhesin, this would mean that the chance of producing monoclonal antibodies against an epitope which is involved in recognizing the receptor structure is very low.

\section{ACKNOWLEDGEMENTS}

This work was supported by the Dutch Kidney Foundation (Grant No. 81320). We are grateful to H.A. Valkenburg (Erasmus University, Rotterdam) and P.A.M. Guinee (State Institute for Public Heallh, Bitthoven) for support and advice. We thank Irma van Die (State University of Utrecht) for restriction site analysis of the cloned plasmid.

\section{REFERENCES}

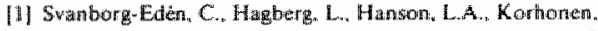
T. Leffler. H. and Ollang. $\mathrm{S}$. (1987) in Adhesion and Microorganism Pathogenicity Ellwh, Ka Ed.), Cibat Foundation Symposium, Vol. go, pp. 161-187. Pitman Medictal London.

[2] Van den Bosch, J.F., Verboond-Sohmer, U.. Postma, P. De

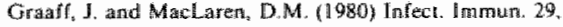
$226-233$.

[3] Van den Eoseh, J.F. Postma, P, Koopman, P.A.R, De Graff, J and MacLaren, DM. (1982) J Hyg. 88.576-577.

[4] Kallenius, G., Svensson, SB. Molby, R. Cedergren, B. Hinllberg, H. and Wind berg, I. (1981) Lancet ï,604-606.

[5] Vaisäneณ, V., Korhonen, T.K., Jokinen, M. Gahmberg. C.G. and Ehnholm, G. (1982) Lancel i $^{1192}$.

[6] Korhonem, T.K., Waisänen Rheni, V., Rhen. M. Pere. A.. Parkkinen, J. and Finne, J. (1984) J. Bacteriol. 159 . $762-766$.

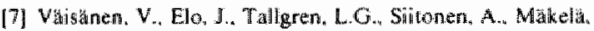
P.H., Svartborg-Eden, C., Kallenius, G., Svenison, S.B... Hultberg. H. and Korhonen. T.K. (1981) Lancen ii, $1368-1369$.

(8) Leffler, H. and Swanborg-Edén. C. (1980) FEMS Micro. bivil. Lett. 8, 127-11.4.

[9]. Wrskow, I. and Orskow, F. (1983) in Host Parasile Re Iationsheps in Gram-negatioe infections. Progress in Allergy (Hanson, L.A., Kallos, the and Westphal, O., Eds.). Vol. 33. pp. 80-105. Karger, Basel.

[10] Parry, S.H. Abraham, S.N. and Susman, M. (1982) in Clinical. Bacteriological and Immunological Aspects of Urinary Tract Intections in Children (Schulte- Wissermian, H.. Ed.) pp. 113 126. Thieme, Stuttgart.

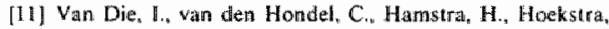

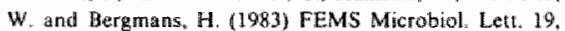
$73-82$.

[12] De Ree, J.M., Schwillens, P., Promes, L., Varu Die, I. Bergmans, H. and Van den Blosch, V.F. (1985) FEMS Microbiol. Lett. 26, 163-169.

[13] Clarke, L. and Carbon, J. (1978) J. Mol. Biol. 120, 517-332.

[14] Bioliwar, F., Rodriguez, R.L., Greene, P.J., Betlack, M.C. Heyneker, H.L.. Boyer, H.W. Crosa. J.H. and Falkow, S. (1977) Cone 2, 95-113.

[1S] Chang A.C.Y. and Cohen, S.N. (1978) J. Bacteriol. 134, $1141-1156$.

[16] Hall, R.A., Gill, R. E, Hisu, P. Minshew, B.H. and Falkow, S. (1982) Infecl. Immoun. $33,933-938$.

[17] Burrsboim, H.C. and Doly. J. (1979) Nucl. Acids Res. 7. i $513-1523$.

[18] Kushmer, SR (1978) in Genetic Engineering (Bloyer, H, W, and Nicosia, S. Eds, j, pp, 17-23. Elsevier, Amsterdam.

[19] Korhonen, T.K. Nurmiaho, E., Ranta. H. and SwanborgEàén, C. (1980) Infect. Immunin. 27, 569-575.

[20] Lowiry, O.H. Rosebrough, N.J., Farr, A.L. and Randall, R.I. (1951) 1. Biol. Chen. 193, 265-275.

[21] Lugtenberg, B., Meijers, J., Peters R., Van den Hoek. P. and Van Alphen, L. (1975) FEBS Lett. 58, 254-258. 
[22] Mulerman, H.G. Ter Hart, H.G.J. and Van Dijlk. W. (1982) Anal. Biochem. 120, 46-51.

[23) Dodd, D.C and Eisenstein, D.1. (1982) Inlect. Immun 3 (s, $764-773$.

[24] Normark. S., Lark. D., Hwll, R., Norgren, M.. Bagm, M. O'Hanley, P., Schoolnik, G. and Falkow, S. (1983) lnfech. Immun. 41. 942-949.

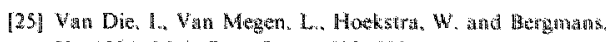
H. (1984) Mol Gen. Genen $528-53 \%$

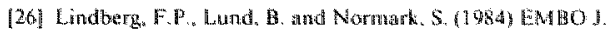
3. $1165-1173$.

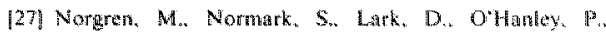
Schoolnik, O. Fallkow, S. Svarbong- Ed ha, C. Baga. M. and Uhlin, B. (1984) EMBO J. 3. 1159-1765 


\section{MOWOCLONAL AWTIBODIES THAT RECOCNIZE THE P PIMBRIAE E7, F? ${ }_{2}$ F9, AND F11 PROM UROPATHOGEHIC ESCHERICHIA COLI}

One of the mast important virulence factors of uro.

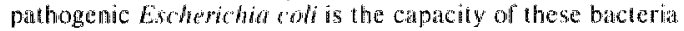
10 adhere to diroepithelial cells $16,22,261$. Adhesion is mediand by fimbriate which arte beterogenous serologically (18, 19,201 and wath regard to the molecular weights of their subunit proteins (8). Grskov and Orskow (18) distinguished equth serologically difenem finbriat in uropathogenic $E$. coln, and Parry el al (20) found seven strologically difterent fimbriae. Fimbriac from unopahogenic $E$. coli can also be distinguishthed by the receptor specificities: (i) fimbrite that cause manwose sensilive hemagglutimation of guinea pig enythocytes (type l farmbriae); (ii) fimbriae that cause no hemagglutingtion (HA) of any erythrocyles (e.g. IC fimbriae); and (iii) fimbriate that catase mannose-resistant hentgglutimation (MRHA) of human erythrocytes. This last group can be subdivided on the basis of receptor specificities into $\mathbb{P}, M, S$, and $X$ fimbriae $(9,12,24)$. The $P$ finbriac copecially thave been associated with the pathogenesis of pyelonephuritis (23). Recently, the molecular cloning of seva tal fimbriac wis reporned. Hull el al. (7) and Cleng (2) described the molectlar cloning of pyelonephritis-associated pilus (Pap) fimbriae and "Clegg" fimbriate respectively. both serologicslly not determined but not cross-reactive with each wither (2). The rollowlot cloning of the genes coding for $F 7_{1}(2 y), F 7_{2}(28)$, and $1 \mathrm{C}$ (27a) himbriac from one parental strain was recently reponted. The fimbriae cloned by Rhen al al. (21) whe presumably the same as the $F F_{1}, F 7_{2}$ and $1 . \mathrm{C}$ fimbrian, but they were cloned from another purental strain. We hawe recently reported the molecular cloning of $F 9$ (3) and (51] (3a) fimbriae, and Hacker ef al. (5) deseribed the cloning of $X$ fambriac from a uropathogenic $E$. coll strain. Ormilorm and fallow (17) cloned type 1 fimbriae from a clinical isolate of eroli. and Klemm at al (9a) cloned type 1. fimbrate from an $E$, coll $K-12$ strain.
In the present study, we describe the production and characterization of polyclonal and monoclonal amberath

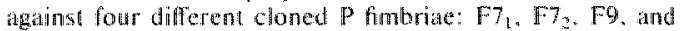
$\mathbb{F} 11$.

\section{MATERIALS AND METHODS}

Bacterial strains, plasmids, and growth nedia. AM1727 is a recA derivative of JE2571, an $E$. coll $K-12$ strain defoient in the production of ype 1 fimbriae (28\%. All fimbribe used in this study were purified from AM1727 harboring the chones described in Table 1 . The F7. F7, and $1 \mathrm{C}$ clones were kindly provided by 4 rona van Die, the Pap clone was provided by Staffan Normark. and pDCI was provided by Steven Clegg.

All bacteria wete cultivated on brain heart infusion agar (Oxoid Lat.). except that strin AM1727 harboring PPIL38 was grown in brain heart infusion broth. Selective pressure agnimst the loss of plasmids was imposed by adding $50 \mathrm{~kg}$ of ampicillin. $100 \mu \mathrm{kg}$ of chloramphenicol, or $12.5 \mathrm{\mu g}$ of teriacycline per ml, dependent on the cloming vector used.

Puriffication of fimbriae. Fimbriac were purified essent allly by the metlood of Korhonen et al. 1103 with some modifications, yielding purified native fimbrias as described previously (3). Purity was checked by sodiun dodecyl sulfate ISDS J polyacrylanide gel sectrophores by the method of Lugtenberg at al. USt. Fimbriat concentrationts were measured by the method of Lowry et al. 14).

Polyclonal antisera. Rabbits were inoculated intra. musculary on days 0 . 9 , and 18 with $400 \mu \mathrm{g}$ of purified fimbriae in Freund complete adjusint (Difco Laboratories). Serum was collected 5 days after the last injection.

Hybridoma production. For immunization, BALB/c mice were inoculated intravenously wia the tail wein with $10 \mathrm{Hg}$ of purified fimbriat in 0.5 mil of saline on days 0.5 and 10 . Foum days after a booster injection with the same amount of limbriae, the mice were killed, and $4 \times 10^{2}$ spleen cells were combined with $2 \times 10^{7}$ cells of the nomproducing myelome cell line SP2/O. Spleen cells and myetoma cells were fused by using polyethylene glycol (PEG 4000$)$ and suspended in 


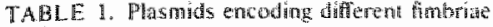

\begin{tabular}{|c|c|c|c|c|}
\hline 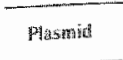 & $\begin{array}{l}\text { Finta. } \\
\text { wrace }\end{array}$ & Moll het & $M A$ & 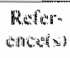 \\
\hline PUL $110-70$ & $F$ & 22.000 & MRHA & 29 \\
\hline FIL $110-37$ & 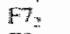 & 19.160 & $\mathrm{MRHA}$ & 2 \\
\hline 911288.10 & $\mathrm{Fg}$ & $2: 0 n$ & $M R H A$ & 3 \\
\hline PHI.24 15 & $F 11$ & $18,0 \mathrm{n}$ & $M \mathbb{R H}$ & 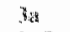 \\
\hline$P R H U 8+5$ & Pip & 19.500 & MRHA & 1.7 \\
\hline 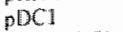 & Clegg & 17.000 & MRHA & 2 \\
\hline pPILIDLSO & $1 \mathrm{C}$ & 75,400 & Nome & $37 i$ \\
\hline$p$ pli.3n & $1 . A$ & 15.766 & $\begin{array}{l}\text { Mannose-sensibitue } \\
\text { Hin }\end{array}$ & 9 \\
\hline
\end{tabular}

complete growh medium (Dulbecon modificd Earigle me-

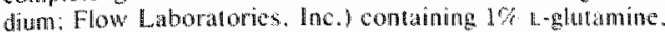
$1 \%$ pymate (Sigma Chemeal Co.), nomessentiall amino acids (Flow). 15\% tetal call serum (GUBCO laborames). 2\% hypoxanthine (Merck \& Co. Inc, 2\% desoxythymina (Merck), and $1 \%$ arninopterin (Sigma). Afte treing seeded in four moroliter plates $(96$ wells). the cells were grown in in $5 \%$ $\mathrm{CO}_{2}$ atmosphere at $37^{\circ} \mathrm{C}$ and $95^{\circ}$ hu hidity. After 3 wews of incubation, all wells were tested for antibody production agains fimbrine whth an enzyme-linked immunosorbend alssay (ELUSA). Positive clones were ransformed to 24 well plates for additional growh. followed by a timiting dilution step to obtain cell lines derived from one single hybrid cell. After additional growth, the cells were used for antibody production in ascitic flud.

Production of ascitic fluid. Pristane-primed BALB/e mice were irradiated wittin 450 rads, One day after irradiation, the mice were inoculaned intraperitoneatly with $5 \times 10^{\text {h }}$ hybrid. oma calls in $0.5 \mathrm{ml}$ of saline. Ascitic fluids werc collected after 6 to 12 days. Lipids were removed with Freon 113, and complement was inactivated by incubation of the ascilic fluid at $56^{\circ} \mathrm{C}$ for $30 \mathrm{~min}$, followed by precipitation in $50 \%$ ammonum sulfate. The precipitate was dissolved ju saline. dialyzed agatnst saline, and frozen in small portions at $-70^{\circ} \mathrm{C}$.

ELISA for anti-fimbrial antibody determination. The ELISA used in this study was a modification of the procedure described by Dodd and Eisenstein (4). Microtiter plates activated polyvinyl chloride; Flow) were conted overnght at $30^{\circ} \mathrm{C}$ with $100 \mu$ per well of a fimbura solution $(2.5 \mu \mathrm{g} / \mathrm{ml})$ in $0.05 \mathrm{M}$ bicarbonale coating buffer $(\mathrm{pH}$ 9.6\%. The plates were washed three times with phosphate-bufend saline-0.05\% Tween 20 $1 \mathrm{PBST}$. For hubridoma screening. the wells were incubated with $100 \mu$ of supenatant for 2 th th room temperature. For titer zletermimalions and spocifiny testing, the wells were incubuted with serist dilutions of polyclonal antiserum or monoclanallantibodies (MAbs) in PBST containing $0.5 \%$ bovine serum albumin (Bothringer Manoheim Biochemicals). Subsequently, the wells were washed three limes with PBST, followed by incubstion with conjugate for $3 \mathrm{~h}$ at room tempetature. In the case of $\mathrm{M} A$ brs. goat antimouse imomunoglobulin $\mathrm{G}$ (IgG) (heary and ligh chairs) conjugated to peroxidase (Nordie Laboratories was used, and in abe case of polyclonal ant iserum, goat antirabbi $\lg G$ (heavy and ligh chains) conjugated to peroxidase (Nordic) was used. Anti-fimbrial antibody activity was detected colorimetrically by adding $0.04 \%$ menylened amine in cilraterphosphate buffer $(\mathrm{pH} 4.5)$ to $0.005 \% \mathrm{H}_{n} \mathrm{O}$. The reaction was developed in the dark for 15 min at room temperature and stopped with $2 \mathrm{M} \mathrm{H}_{3} \mathrm{SO}_{4}$. The $\mathrm{A}_{42}$ was measured in a Titertek Multiskan (Flow).

Class determination of MAbs. After microtiter plates were

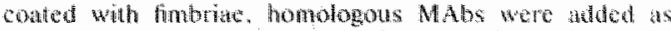
described for the ELISA. Aner three whonges wh PBST

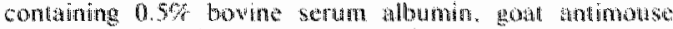

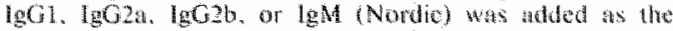

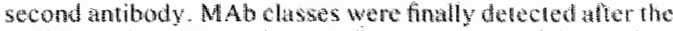

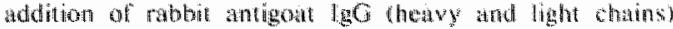
comjughed to perowidase (Nontic).

Spot fust for the reaction of MA bs with denatured fimbrata.

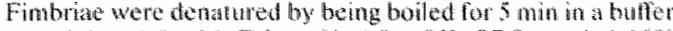

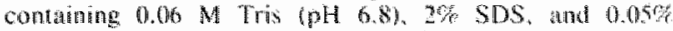

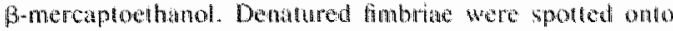

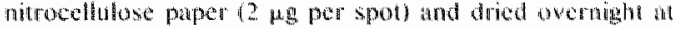
room lemperwture. The nitrocellulose paper was blocked with $1 \%$ bovine setum atbum in PBSt for 1 h at $37 \%$.

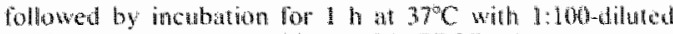

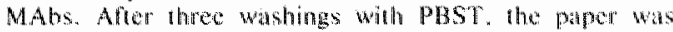

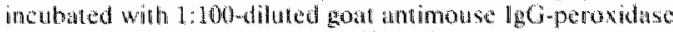

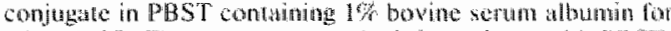

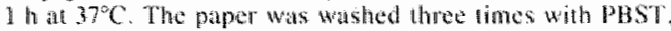
and immune complexes were detocted by anding $0.05 \%$

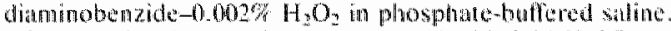
After 10 min. the renction whs stopped with $2 \mathrm{M} \mathrm{H}, \mathrm{SO}_{4}$

HA assays. The HA activity of human erythocytes and that inhibition of $\mathrm{HA}$ ware determined by the method of wat den Bosch et al. (25). Bricty, serial dilutions of Bacteria we incubated with human erythocyles for 2 h on ice. HA wis read aflet agitation. The inhibition of HA was lested wibn bacteria preincubated for $30 \mathrm{~min}$ at room lemperarure with polyolons andiserum or MAbs. Anthody ditutions which dad not cause agglutination of bucteria as chened by micros copy, were used.

\section{RESULES}

Charracterization of polyclomal antisera ratsed against $f 7$. $\mathbf{F}$, F9, and Fll fimbriat. All finbriat were purifed as described in Muterial and Melliods. The prity of these fimbria preparations was checked by SDS-polyacrylamide gel electrophoresis (Fig. 1). Polyclomal antiseta wer ranted in rabbits agents purified $F 7_{1}, F 7_{2}, F 9$, and Fil hobriat. Cross-reactions of these polyclonal antiserat with atl pulfed fombriate were andyzed in an ELISA. All polyclond antiserat reacted strongly with the homologens fimbriate thable 2 ). However. all polyclonal antiseratso reated with the heterologous hombriac, although with lower liters than in the homologots renctions. The anti-F7, antiservan reacted with all the finbriate exept the pap fimblitio. In the case of anti-F7, antisertim, posivive reactions were found with all but the $1 \mathrm{~A}$ fimbrite. "The anti-Fin antiscom routed strongly

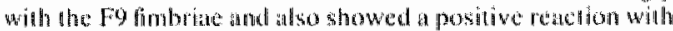

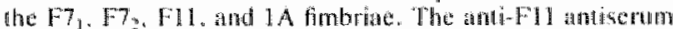
showed the highesd tiess aganst Fl 1 and Clegg fimbrite and atso recognized antigenic determinants on the olner fimbrise which catse MRHA hut nol on the $1 \mathrm{~A}$ and $1 \mathrm{C}$ formbriat

Mab production. Purfied $\mathrm{F}_{1}, \mathrm{Fq}_{3}$. Fy, and Fll fimbrithe were uscd for MAb production as duscribed in Materat and Methods. Thee weeks after the wations liusions. the hybrid onds with the highest BLISA tesilts were selocted for additional growth. After subcloning, the bybridomes with the highes aters in the ELISA were used lor the production of ascitic fluds. and the imntonoglobulins wete character-

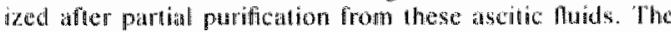
results of the immunoglotidin subctass detcrmintions are shown in Table 3. Six MAbs were of the llgCil sultactass. six were of the $\lg M$ subclass, three wete of the lgC2b subchas.

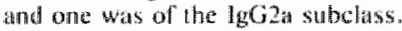

Characterization of $\mathrm{MAb}$ raised agalnst $F 7_{1}, 17_{2}, \mathrm{Fy}$, and 

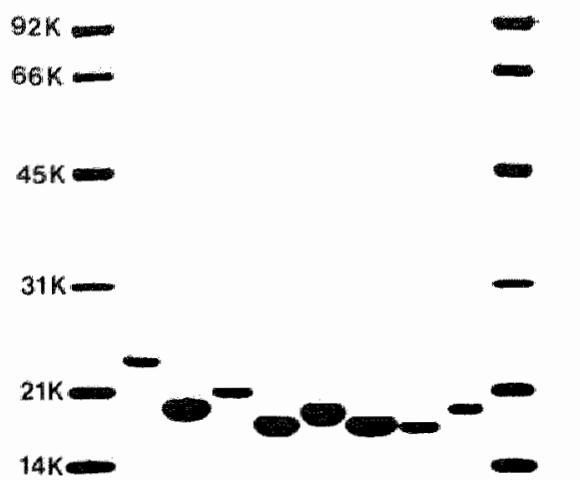

\section{$m a b c i g h m$}

FIO. 1. SDS-polyterylamide gellectropheresis with difieren

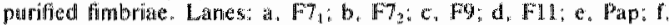
Clegg: $\mathrm{g}, 1 \mathrm{C} ; \mathrm{h}, \mathrm{LA} ; \mathrm{m}$, marker.

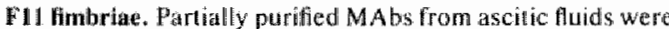
tested in the ELISA for (cross-)reactions with all purified fimbrike. In "Trble 3, the titers are shown for each $\mathrm{MAB}$ againsil homologous and theterologous fimbriat. The four M6 MAbs raised against F 7 fimbriate only recognized an epitope on $\mathrm{F}_{1}$ fimbriae. All three MA MAbs, which were produced agginst Fo fimbriac, recognized only eputopes on F9 fimbriae. The M2 MAbs "ratsed against $F 72$ fimbriae, could be divided into wo groups: M2-7, which only recognized an epitope on $\mathrm{F}_{2}$, fimbriae, and $\mathrm{M} 2.1$ and $\mathrm{M} 2-11$, which recognized epitopes on F7, and F9 firibriac. The M7 MAbs, raised against [fll limbriae, could also be divided into two groups: two MAbs (M7-5 and M7.15) which recognized epitopes on F11, F7, and Pap fimbriae, and a group of four MAbs (M7-4. M7.6, M7-7, and M7-13) which recognized epitopes on Fll and Clegg fimbriae.

Purification of MAbs by high-pressure liquid chnomatography yiclded anlibodies which still showed the same (cross)-reactions as partially purified MAbs. Since immunization and the ELISA were performed with native fimbriae. we analyzed the reaction of the MAbs with denalured fimbriace in a spol test as described in Materialls and Methods. Onty lwo sets of MAbs reacted with denatured homol ogots firmbutue (Fig. 2). Firstly, both the M2.1 and M2.11 MAbs reacted with denatured Fy, firmbrise, and secondiy, Whe M7-4, M7-6, M7-7, and M7-13 MAbs showed a positive

TABLE 2. Cross-reations of polyctonal antisere in an ELISA with choned, purified fimbrite

\begin{tabular}{|c|c|c|c|c|c|c|c|c|}
\hline \multirow{2}{*}{ 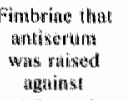 } & \multicolumn{8}{|c|}{ Antibusdy ther" on indicared fimbriac } \\
\hline & $F$ & $\mathrm{Fl}_{3}$ & $\mathrm{Fr}$ & Fil & Prap & Cikg & iA & $1 \mathrm{C}$ \\
\hline 17, & $\$ .0$ & 4.1 & 4.1 & 2.9 & & 20 & 2.6 & 2.0 \\
\hline $\mathrm{Fl}_{\mathrm{z}}$ & 3.5 & 90 & 4.1 & 3.2 & 2.9 & 2.9 & & 2.0 \\
\hline $\mathrm{P9} 9^{\circ}$ & 2.0 & 12 & 4.7 & 2.3 & & & 2.3 & \\
\hline Fil. & 3.5 & 3.5 & 3,2 & 4.4 & 3.2 & 4.4 & & \\
\hline
\end{tabular}

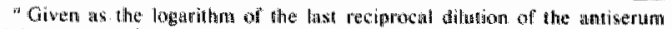
giving ary $A_{\text {dian }}$ of a duest 0.5 .
TABLE 3. Titers of MAbs in an ELLA with eigh diferent purffied fimbrize and subclasses of antiboules

\begin{tabular}{|c|c|c|c|c|c|c|c|c|}
\hline \multirow{2}{*}{ UAb } & \multirow{2}{*}{ 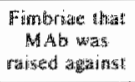 } & \multirow{2}{*}{ 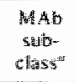 } & \multicolumn{6}{|c|}{ 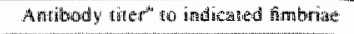 } \\
\hline & & & $\mathrm{F}_{\mathrm{f}}$ & $F H_{4}$ & $F 9$ & Fil & $P a p$ & Clageg? \\
\hline $\mathrm{M} 6 \mathrm{6}-3$ & $\mathrm{~F}_{i}$ & $\lg (\mathrm{C} 2$ & 4.4 & & & & & \\
\hline$A\left(x_{n}-6\right.$ & & $\lg \mathrm{w}$ & 38 & & & & & \\
\hline M6:8 & & $\lg B$ & 4.1 & & & & & \\
\hline $\mathrm{M} k \mathrm{k}-19$ & & IgH & 4.7 & & & & & \\
\hline M-4.5 & $\mathrm{mg}$ & $\lg 4$ & & & 4.1 & & & \\
\hline$M 4-7$ & & $\lg M$ & & & 4.7 & & & \\
\hline$M 4-11$ & & $\lg M$ & & & 3.5 & & & \\
\hline$M 2.1$ & $\mathrm{FT}_{4}$ & $1202 b$ & & 50 & 3.8 & & & \\
\hline$M 2-11$ & & $\operatorname{lgO} 1$ & & 35 & 2.0 & & & \\
\hline$M^{2}-7$ & & $\operatorname{lgCi}$ & & 4.4 & & & & \\
\hline$M 7.4$ & FIH & $\operatorname{lgCi} 2 t$ & & & & 4.4 & & 4.1 \\
\hline$M 76$ & & $\operatorname{lgCl}$ & & & & 50 & & 50 \\
\hline$M 7.7$ & & $\lg C 2 b$ & & & & 4. 首 & & 4.1 \\
\hline$M 7-13$ & & $\lg G 1$ & & & & 4.4 & & 4.1 \\
\hline M7.S & & $\lg G 1$ & & 4.1 & & 4. 1 & 3.8 & \\
\hline$M 7-15$ & & $\lg C 1$ & & 4.7 & & 4.1 & 3.5 & \\
\hline
\end{tabular}

"Determined as described in Malerials and Methods.

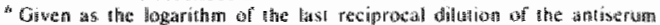

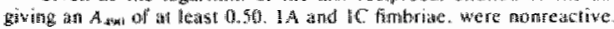

reaction with denatured 1511 fimbriae. These $M 2$ and $M 7$ MAbs also racted with the denalured heterologous F9 and Clegg fimbriae, respectively (data not shown).

HA inhibition assays. The MRHA titer of AM1727 with different clones was lested in an HA assay. All four clones showed MRHA, and this MRHA was completely inhibited in the presence of the homologous polyclonal antiserum rTable 4). In the presence of MAbs no intuibition of MRHA was observed.

\section{DISCUSSION}

In this study, we described the production of polyclonal antisera and MAbs against the four purified $\mathbb{P}$ fonbriae $F F_{1}$, F7, $\mathbb{F 9}$, and F11. All fimbriae were purified from cloned strains. The main advantage of using cloned strains instead of parental strains is that cloned strains only express one type of fimbria, whereas parental strains can express different types of fimbria, e.g. C 1212 , which expresses FI. $\mathrm{F}_{2}$, and $1 \mathrm{C}$ fimbriae (28). Another ad vantage of using cloned

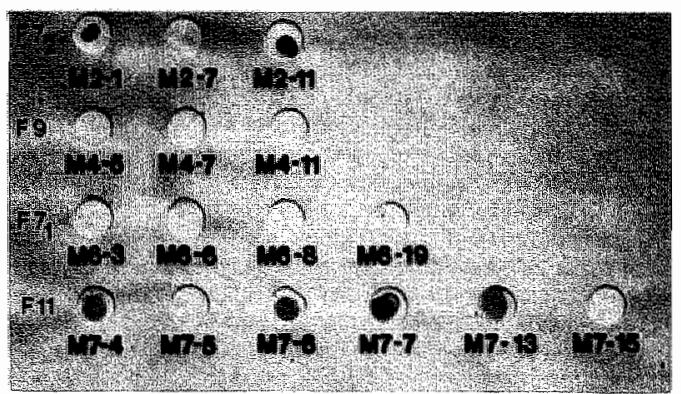

FIG. 2. Spot test with MAbs and denatured fimbrine. 
TABLE 4. HA inhibition by polyclonal antisera and MAR:

\begin{tabular}{|c|c|c|}
\hline 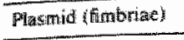 & Antisertan & HA thiter \\
\hline \multirow[t]{5}{*}{ pPILIHO-3F (F/2) } & None & 128 \\
\hline & Polyclonall & 0 \\
\hline & M2-1 & 04 \\
\hline & $\mathrm{M} 2-7$ & 64 \\
\hline & $\mathrm{M} 2-11$ & 64 \\
\hline \multirow{5}{*}{ pPIL $288-10(F 9)$} & None & 256 \\
\hline & Polyclonal & $a$ \\
\hline & $M 4-5$ & 128 \\
\hline & $M 4-7$ & 128 \\
\hline & M4.11 & 128 \\
\hline \multirow[t]{6}{*}{ pPlL110,70 (F/, } & None & 128 \\
\hline & Polycional & 0 \\
\hline & $M 6-3$ & 128 \\
\hline & M6-6 & 64 \\
\hline & M6-8 & 64 \\
\hline & $M 6 \div 19$ & 32 \\
\hline \multirow{8}{*}{ pPIL291-15 (F-1) } & None & 128 \\
\hline & Polyclonal & 0 \\
\hline & M7-4 & 128 \\
\hline & $M 7-5$ & 128 \\
\hline & $M 7-6$ & 128 \\
\hline & $\mathrm{M} 7 \cdot 7$ & .128 \\
\hline & $M ?-13$ & 128 \\
\hline & M7-15 & 128 \\
\hline
\end{tabular}

strains is that these strains give rise to high fimbria production. which facilitates the purification of fimbriae. All: fumbriae used in this study were pure, as showed by SDSpolyacrylamide gel electrophoresis (Fig. 1). Polyclonal antisera raised against purified fimbriae reacted with the homologous fimbriae (Table 2) but also with other fimbriat. These results are in agreement with the results of Korhonen et al. (11). who made a set of antisera raised against purifed fimbriae from parental strains. These fimbria preparations did contain different fimbriane, because the parental strains possessed different lypes of fimbria. Our fimbria preparations only possessed only type of fimbria, and the amtisera raised against these fimbriae still showed numerous crossreactions in the ELISA (Table 2). This result indicates that these fumbriae have various antigenic determinants in commons.

With the same pure fimbria preparations we produced a set of MAbs agdinst $F 7_{1} . F 7_{2}, F 9$, and $\mathbb{F l l}$ fimbriac. The MAbs against F7, and. Fo fimbriae only recognized epitopes on $\mathrm{Fl}_{1}$ and $\mathrm{F} \times \mathrm{g}$ fimbriae, respectively. It is not yet certain whether both series of MAbs recognize the same or different epitopes within eact series. Recent data from DNA sequencm ing of the fimbria genes coding for the Pap (1) and $\mathrm{FT}_{2}$ (27) fimbriae indicate that there are several pronounced antigemic determinamts on fimbriae. Thus, it might be possible that the M4 and M6 MAbs recognize different epitopes on F9 and F7. fimbriae, respectively. The $\mathrm{M} 2 \mathrm{MAbs}$, raised against $\mathrm{FT}_{2}$ fimbriae, could be divided into two groups: the $\mathrm{M} 2.7 \mathrm{MAb}$. which only recognized an epitope on $m_{2}$ fimbriae, and the M2-1 and M2-11 MAbs, whicll recognized epitopes on $\mathrm{F7}$ and F9 fimbriat. From these results, conclude that M2-1 and $M 2 \times 11$ probably recognize the same epitope and that this epitope is only present on $\mathrm{FT}_{2}$ and $\mathrm{F} 9$ fimbriae. This conc $\mathrm{u}_{\mathrm{u}}$. sion was supported by the spot test with denatured limbriae. Both $\mathrm{M} 2-1$ and $\mathrm{M} 2-1 \mathrm{li}$ recogmized epitopes on denatured $\mathrm{Fi}_{2}$ and F9 fimbrias, ir contrast to M2-7, which did not reat with denatured fimbrial. The M7 MAbs, rased aganst Fll fimbriae, could also be thivided into two groups: MA Mas (MT.5 and M7-15) which recognized epitopes on F11. F\%, and Pap fimbriae and a group of four MAbs (M7-4. M7-6. M7-7, and M7-13) which recognized epitopes on foll and Clege fintoriae. This lasit group of MAbs also recognized eptopes on denatured F 11 and Clegg fimbrian, sts shown in the spot test, in contrast $10 \mathrm{M7} \times 5$ and $M 7-15$, which did not react with denatured fimbriae. From these results, we conclude that $M 7-5$ and $M 7-15$ probably recognize the same epitope and that this epitope is presern in $\mathbb{F} 11, F_{2}$, and Pap fimbriate. It is likely that $M 7-4, M 7-6, M 7.7$, and $M 7-13$ also recognize a commor epitope on Fil and Clegg fimbriate but that this epitope is different from the one recognized by M7-5 and M7-15.

Most of the MAbs did not react with denatured finbriae. This is not surprising, because the nace were immunized with native fimbriae. The reaction of MAbs M2-1, M2.11, M7-4, M7-6, M7-7, and M7-13 with denatured fimbriac Suggests that the epitopes recognized by these MAbs are not involved in a quaternary structure. Ith contrast ${ }_{n}$ all polyclonal antisera tested so far have reacted strongly with denatured fimbriae $(3,3 a)$. Furthermore, the MAbs were fiar more specific than the polyclonal antisera. The most likelly explanation for these differences between MAbs and polyclonal antisera is that an MAb only recognizes one epitope. whereas a polyclonal antiserum recognizes many epitopes. some of which are also present in heterologous $P$ and even type 1 fimbriae. This is supported by the finding that the combination of two different MAbs raised aganst F1l firmbriae (e.g. M7-4 and $M 7-5$ ) alleady recognized four different $P$ fimbriae.

No inhibition of MRHA by MAbs was found, in contrast to the complete unhibition by polyctonal antisera (Table 4). Recent data from Norgren et al. (16) and Lindberg et al. (13) indicated that the adhesin of Pap fimbriae is a minor component of these finbriae. Since this is also the case for the $\mathrm{F7}_{1}, \mathrm{Fr}, \mathrm{F} 9$, and F11 fimbriae (1. van Die, E. Zuidweg, W. Hoekstra, and H. Bergmans, FEMS Meeting on Molecular Biology of Microbial Pathogenicity, 17-20 June 1985, p. 18), it is not surprising that we were not able to select an $\mathrm{MAb}$ which inhibited MRHA. The probability of finding an MAb which recognizes an epitope involved in the adbesive properties of these fimbriae is very low when the adhesin is only a minor component of the fimbriae. Since the MAbs described in this paper are far more specific than polyclonal antiserit, these MAbs may be useful for diagnostic and epidemiological means. Furthermore, the MAbs can be very helpfal in studies concerning antigenic vatriation ard phase variation of $\mathrm{P}$ fimbriae.

\section{ACKNOWLEDGMIENTS}

This work was supported by the Dutch Kidney Foundation (grant 81.3.20).

We are gateful to H. A. Valkenburg (Erasmus Universily. Rotherdam, The Netherlands) and P. A. M. Ounee (State Institute for Public Health, Bilthoven. The Netherlands) for supporti and advice. We thank Kees Verstijnen and Marc de Basts (State: University of Limbung. Maastricht. The Netherlands) for introducing uss to the hybridoma techniques atsa for wahtuable suggestions diung the experiments.

\section{LITERATURE CITED}

1. Brga, M. S. Narmark, J. Hardy, P. D'Hantley, D. Lark, O. Olsson, G. Schoolnulk, and \$. Falkow*, 1984. Nucleotide sequence 
of the propa gerse enoding the papa pillug subunit of human

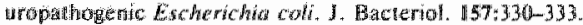

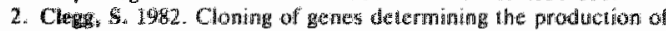

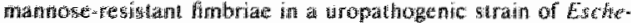
richia coli belonging to serogroup 06 . Infect. Immun. 3.5: 73919.74

1. de Ree, f,M, $P$, Schwillers, L, Promes, 1. wain Mie, H.

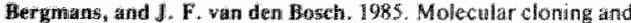
charactrorization of $\mathrm{Fg}$ finlbribe from a uropathogemir Esche

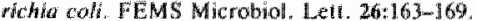

3a de Rher, I. M. P, Schwillens, and d. F, wan den Basch. 1985.

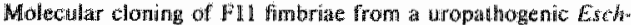
exichia coll and chamicterization of fimbriace with polyctonal and nonoctonal ambodica. FEMS Microbiol Latt. 29:91-97.

4. Dodb, D. C. and B. I. Eisengtein. 1982. Antigenic quantitation of wowe fimbriae an the surface of Escherichita coll cells by an entyme-linked intmunosorbent inhibition aseay". Infect. Immun. $39: 764-773$.

5. Hacker, d., G. Schmidd, C. Hughes, S Knapp, M, Marget, and W. Goebel. 1985. Cioning and characterization of genes involved in production of mannose-resistant. netraninidasesusceptible $(X)$ flmbriac from a uropathogenic $06: \mathrm{K} 15 \mathrm{H} 31$ Escherichia coll sufair. Infect. Immun. 47:434-440.

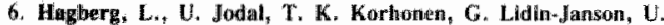
Lindberg, and $C$. Swanborg-Eden. 1981. Adhesion, hemaggluti. nation, and virulence of Escherictlia coli causing urinary tract infections. Infect. Immun. 31:564-570

7. Hull, R, A. R. E. Call, P. Hsu, B. H. Minshew, and S. Falkow, 1981. Construction and expression of recombranan plasmids encoding type 1 ou Dumannose-resistant pili from a urinary tract infection Escherichia coll isolate. Infect. Immun. 33:933-938.

19. Jann, K., B. Jarm, wand G. Sichnidd. 1981. SDS-polyacry lamide gel electrophoresis and serological analysis of pili from $E$ scherichia coll of different pathogenic origin. FEMS Microbiol. Let. $11: 21-2.5$

9. Kalllendus, G., S. B. Swensson, R. Mollby, B Cedergren, H. Haltherg, and J. Windberg, 1981 . Sirtecture of carbohydrate part of receptor on humat uroepithelial cells for pyetonephritogenic Escherichia coli. Lanced il: 604-606.

98.Klemm, P., B. J. Jorgensem, J. wan Die, H. de Rhee, and H. Bergmans. 1985. The fim genes responsible for syuthesis of type 1 fimbriac in Escherichia coll, cloning and genetic organization. Mol. Gen. Gene $199: 410-414$.

10. Korhonen, T. K. E. L. Nurmiahw, H, Ranta, and C. SvanborgEden. 1980. New method for isolution of immunologically pure pili from Escherichia coli. Infect. Immun. 27:569-575.

11. Korhonen, T. K., V. Vaistanem, H. Saxen, H. Llultberg, and S. B. Svenson. 1982, p-antigen-recognizing fimbritac from human uropathogenic Escherichide coll strains. Infect. Immun. $37: 286-291$

12. Korhosen, T. K., $\vee$. Vaisänen-Rhen, M. Then A. Porc, J. Parkkimen, and J. Finne, 1984. Escherichtis coll fimbriae recognizing sialyl gollactosides. J. Bacteriol. 159:762-766.

13. Lindbern, F. P., D. Luad, and 5 . Normark, 1984. Gienes of

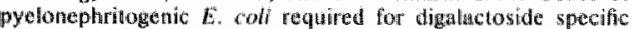
agglutination of human cells, EMBO J. 33:1167-1173.

14. Lawry, O. H., N. Ji. Rosebrough, A. L. Farr, and R. J. Randall. 1951. Protein mensurement wioh the Folu phenol resigent. J. Biol. Cherm. 193:265-275.

15. Lugtenbery, G., J. Meyers, R. Peters, P. van den Hoek, and L. van Alphun. 1975. Electroghoretic reselution of the majior outer mentrane proteins of Escharichia coll $k$ il into lour bands. FELS Letl. $58: 254-258$.
16. Mortaren, M. S. Nermark, D. Lark, D. O"Hanley, G. Schoolnik S. Fagk w

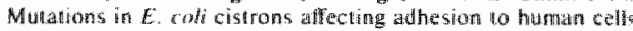
do not atolish Pay pill fiber formation. EMBO J. 3:1159-1365.

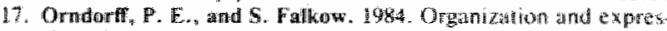

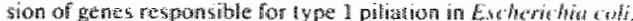
J. Bacteriol. 159:736-744.

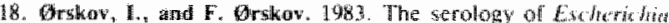
coll finbriac. Allergy 33:80-105.

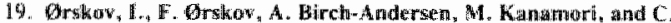

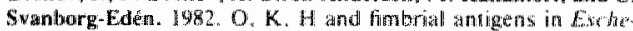

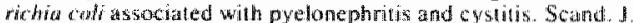
Infect. Dis. Suppl. 33:18-25.

20. Parry, S. H., S. N. Abraham, and M. Sussman. 198?. The biological and serological properties of adhesion duermiman: of Easherichia coll isolated from urinary trace infections. P. 113-126. in H. Sehelte-Wissermun ted.j. Chnical bacteriolog. cal and ifmmonotogicent aspecs of urinary lracl infectiuns in children. Georg Thieme Verlag. Stungat:

21. Khen, M.., J. Knowhs, M. E. Penttila, M. Sarvas, and T. K.

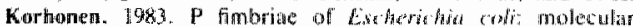
cloning of DNA fragments containing ithe structural genes. FEMS Microbici. Lett, 19:11\% 123

22. Svanhorg-Edén, C. L. A. Hanson, U. Jod al U. Lindberg, and A. Soh-Akerlund. $197 \%$. Variable atherence to normas human urimary epithelial cells of $E$. folf strains associatted with varous forms of urinary truet infections. Lancet fat40-492

23. Väisänen, V., J. Elo, L. G. Tallgren, A. Siitonen, H. Hakeli, C. Skanborg-Edorn, G. Killenilus, S. B. Svenson, H. Hultberg, and $T$. Korhonen. 1981. Mannose-resistant hatemagglatinat

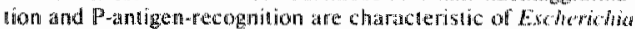
coli catising primary pwelonephritis. Lancel in $1360-1369$.

24. Vătsäner, V., T. K Korhonen, M. Jokiner. C. G Gahmbers, and $C$. Ehnholm. 1982. Blood group $M$ spreific hatemagglatinin in pyelonephritogenic Excherichies owh. Lancet i:1192.

25. van den Bosch, J. F." P. Postma, P. A. R. Koopman, J, de Graafl, and D. M. Maclaren. 1982. Virulence of unintry and

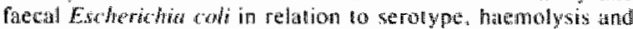
haemagetutination. J. Hyg. 88:567-577.

26. van den Hosch, J. F, U. Verboom-Sohmer, P. Postma, J. do Graaff and D. M. MacLaren. 1980. Marnose-sensinike that mannose-resistant atherence to human uroepithelial cells and urinary virullence of Encherichio coli. Infech. Imman. $29: 226-233$

27. van Dhe, 1 , and $H$. Bergmans. 1984. Nucleonide sequence of the gene encoding the $F 7_{2}$ fimbral subunit of a uropathogenic

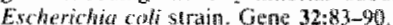

27 a.van Die, I., B. van Geffen, W. Hoekstra, and H. Bergmans, 1984 Type $1 C$ fimbriate of a uropathogenic Escherichin colf strain cloning and characterizat ton of the genes involved in the expres. sion of the $1 \mathrm{C}$ antigan and nucheotide seqtence of the subunit genc. Gine 34:187-196,

28. van Die 1 . C. Van den Hondel, H. Hansira, W. Howkstra, and

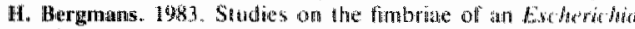

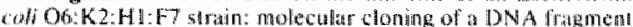
encoding a fimbrial ankigen responsible for thinamose resistant hathengelutination of human erythrocytes. FEMS Microbiol. Lett. 19:77-82

29. wan Die, I., G. Spierings, J, Man Megu, E. Zuidweg, W Hoekstra, and H. Hergmans. 1985. Cloning and genetio organization of the gene cluster encoding F71 fimbriac of a uropathogenic Excherichia coli and comparison with the fFy? gene cluster. FEMS Microbiol. Lett. 28:329-334. 
CHARACTERTZATION OE THE P ETMBRTAE FB AND FI2 EROW UROPATHOGENTC ESCHERTCHIA COLI HTH MONOC DONAL AMIBODTES

INTRODUCTION

Adherence of uropathogentc Escherichia coll to uroepithellal cells is an important step in the pathogenesis of urinary tract infection (Hagberg et a1., 1981; Van den Bosch et al., 1980). This adherence is mediated by fimbriae which can be divided into two groups: 1 fimbrlae which causes a mannose sensitive haemagglutination (MSHA) of guinea pig erythrocytes; il fimbriae that causes a mannose resistant haemagglutination (MRHA) of human erythrocytes. This last group can be subdivided into other groups on the basis of their receptor specificity. Especially the $\mathbb{P}$ fimbriae, which recognize the receptor structure $\alpha-\mathrm{D}-\mathrm{Gal} \underline{\mathrm{p}}-(1-4)-\beta-\mathrm{D}-\mathrm{Gal} \underline{\mathrm{p}}$ on uroepthelial cells (Leftler and Svanborg-Edén, 1980), have been associated with pyelonephritogentc strains (Vaisänen et al., 1981). These P fimbriae were classified in different serotypes e.g. by orskov and Drskov (1983) in F7-F12 and by parry et al. (1982) in a-g. These $P$ flmbriae were also heterogenous with regard to the molecular weights of their subunit proteins (Jann et al., 1981; de Ree et al., 1.985).

Recently described the production of monoclonal antibodiles (MAbs) against the $P$ fimbrlae $F 7_{1}, F_{2}, F 9, F 11$ and $F 13$ (=Pap) (de Ree at al., $1985 \mathrm{~b}, 1986 \mathrm{~b})$. In this article we report the production and characterization of MAbs against F8 and F12 fimbriae. The F12 MAbs were ralsed against 12 fimbriae from the reference strain c1979 ( $\$$ rskov and $0 \mathrm{rskov}, 1983$ ), whereas the F8 MAbs were raised against 18 fimbrlae which were purified from a recombinant strain. The F12 MAbs were also compared with another F12 MAb which was raised against the Fl2 fimbriae from another wld type stratin: 20025 (Jann et a1., 1981). The differences between these F12 MAbs are discussed. 
Bactertal stralins, plasmlds and growth media

HB 101 is an E. col1 K12 strain deflctent in the production of type 1 fimbriae (Boyer and Roulland-Dussolx, 1969). F8 fimbriae were purfied from the straln $1 \mathrm{BB}$ 101 harboring pANN921, which was kindly provided by Jorg Hacker, and from the E. coll strain C1254. The genes encoding for F8 fimbriae were cloned from the wld type E. coli 2980 (Hacker et al., to be published) with secotype 018:K5:H- (Jann et al., 1981). Fl2 fimbriae were purifled from the wild type strain C1979 with serotype 016:Kl:H- (ضrskov and orskov, 1983). All the other $P$ fimbriae used in this study were purifled from strains harboring plasmids encoding for $P$ fimbrlae (de Ree et a1., 1985). All bacteria were cultivated on braln heart infusion agar (Oxold Ltd.). Selective pressure against the 108 of plasmids was imposed by adding $10 \mu \mathrm{g}$ tetracycline per m1. The $C$ and $S P$ strains were kIndly provided by $I$. and $F$. Orskov and S. Parry, respectively.

\section{Purification of fimbriae}

Fimbrlae were puriffed by the method of Korhonen et al. (1980) avolding protein-denaturing conditions (de Ree et al., 1985a). Purity of fimbriae preparatlons was checked by SDS-PAGE (Lugtenberg et al., 1975). Gels were stalned with Coomassie Brilltant Blue.

\section{Hybridoma production}

Monoclonal antibodies against F8 and F12 fimbriae were produced as described recently (de Ree et al., 1985b). Briefly, BALB/c mice were injected intravenously several times with purified fimbriae. The spleen cells were fused with cells from the myeloma cell line SP2/0. After three meeks hybridomas were tested for ant 1 -fimbrlae production in an ELISA. Postive clones were subcloned by a limiting dilution step and grown up for antibody production in ascitic fluld. Antibodies were partially purified from ascitic fluld as described (de Ree et al., 1985b).

The production of the F12 MAb 20025-F2a, raised agalnst the F12 fimbriae from straln 20025 w11 be described elsewhere (C. Abe et al.. Submitted for publication). The $0: K$ serotype and the serotype of the fimbriae expressed by strain 20025 are the same as the strain Cl34 (Drskov and orskov, 1983). 
An ELISA wh purified fimbriae as antigen was cartied out essentially as described (de Ree et al., 1985). Briefly microtiterplates were coated wh fimbriae, followed by Incubation th serial dilutions of MAbs. Anti-fimbrae activity was detected colorimetrically after incubation wh goat-anti-mouse antiserum, conjugated with peroxidase and addition of the substrate o-phenylenediamine. Absorbance at $495 \mathrm{~mm}$ was determined with a Titertek multiscan ELISA plate reader. Cross reaction of the MAbs against other flmbriae was also measured in a fimbriae BLISA.

Whole bacterta ELISA

An ELISA with whole bacteria as antigen was carried out as described (de Ree et al., 1986a). Briefly, bacteria were coated to microtiterplates and preincubated with Wew Born Calf serum, followed by incubation of serlal dilutions of MAbs. Anti-fimbriae activity was measured as described above.

\section{Class determination of MAbs}

Microtiterplates were coated with fimbrlae and homologous MAbs were added as described for the fimbrlae ELISA. Goat anti-mouse IgGl, IgG2a, $\operatorname{IgG2b}$ or IgM was added as the second antibody. MAb classes were detected after the addition of rabbit anti-goat IgG (heavy and 1 lght chalns) conjugated to peroxidase and the substrate o-phenylenediamine.

Mannose Resistant Haemagglutination and Inhibition with MAbs

MRHA and Inhibition with MAbs was determined as described (de Ree et al ", $1985 \mathrm{~b})$.

\section{RESULTS}

F8 fimbrlae were purifled from $\mathrm{Cl} 254$ and the strain $\mathrm{HB} 101$ carrylng plasmld pANN921. Both fimbriae preparations were pure as judged by SDS-PAGE (F1g. 1 , lane $b, c)$ and showed the same mol. welght of 20.000 dalton. MAbs were ralsed against the F8 fimbriae purifled from the strain HBLOI carrylng pANN921. F12 fimbriae, purified from C1979, showed two bands in SDS-PAGE with both a mol. weight of approximately 18.000 dalton (FIg. 1, lane e).

A11 MAbs were tested 10 a flmbriae ELISA to determine the titer againgt homologous and heterologous fimbriae. Al1 F8 MAbs reacted strongly with the 


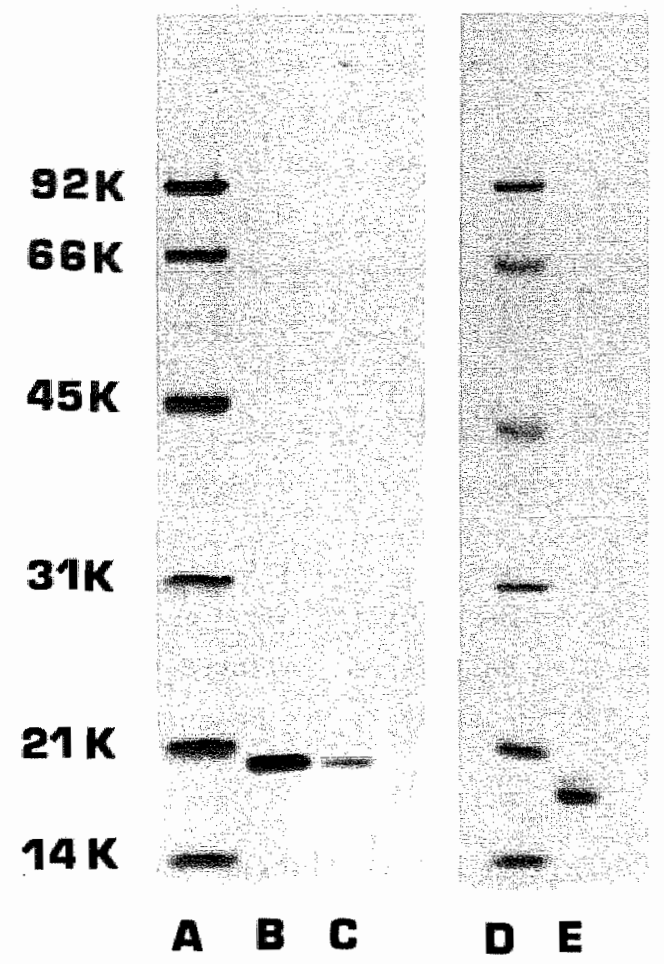

FIG. 1 SDS-PAGE of purified FA and F12 fimbriae. Gels were stained with Coomassie Brilliant Blue.

A. Marker proteins.

B. E8 fimbriae purified from the etrain HB101-pANN921.

C. F8 fimbriae purified from 01254 .

D. Marker proteins.

E. F12 fimbriae purified from 01979 .

homologous $\mathrm{F} 8 \mathrm{fImbr} I \mathrm{ae}$ and the $\mathrm{F} 8 \mathrm{f} \pm \mathrm{mbriae}$ purlfled from $\mathrm{C} 1254$, and showed no cross-reaction with any other fimbriae (Table 1). The F12 MAbs reacted also strongly with the homologous F12 fimbriae. All F12 MAbs were from the IgM subclass type except for M14-11 and 20025-F2a which belonged to the IgG2b subclass type. The F8 MAbs also belonged almost all to the IgM subclass, except for M17-1 and M17-5 which were both from the IgGl type (Table 1). To check whether these MAbs were able to determine the F8 and F12 fimbriae on 
TALE 1: Titer of MAbs in an ELISA with homologous and heterologous flubriae and subclasses of antibodies.

\begin{tabular}{|c|c|c|c|c|c|}
\hline \multirow{3}{*}{ Mab } & \multicolumn{2}{|l|}{ Fimbriae that } & \multirow{2}{*}{\multicolumn{3}{|c|}{$\begin{array}{l}\text { Antibody titer to indlcated } \\
\text { fimbrlae }\end{array}$}} \\
\hline & \multirow{2}{*}{$\begin{array}{l}\text { MAb was } \\
\text { raised against }\end{array}$} & \multirow{2}{*}{$\begin{array}{l}\text { MAb } \\
\text { subclass a }\end{array}$} & & & \\
\hline & & & $F 8^{\mathrm{c}}$ & $F 8^{d}$ & $\mathrm{~F} 12$ \\
\hline$\overline{\mathrm{HIT}-1}$ & E8 & $\operatorname{IgGI}$ & 4,4 & 4,4 & - \\
\hline$M 17-2$ & F8 & $\operatorname{Ig} M$ & 3,8 & 3,8 & - \\
\hline$M 17-3$ & F 8 & $\operatorname{Ig} M$ & 3,8 & 3,8 & - \\
\hline$M 17-4$ & $\mathrm{~F} 8$ & $\operatorname{Ig} M$ & 3,8 & 3,8 & - \\
\hline$M 17-5$ & $\mathbb{F} 8$ & $\operatorname{Ig} G 1$ & 3,8 & 3,8 & - \\
\hline$M 17-9$ & F8 & IgN & 3,8 & 3,8 & - \\
\hline$M 17-10$ & F8 & $\mathrm{IgM}$ & 3,8 & 3,5 & - \\
\hline$M 14-4$ & $\mathrm{EL} 2(\mathrm{C} 1979)$ & $\operatorname{IgM}$ & - & - & 4,1 \\
\hline$M 14-5$ & F12 (C1979) & $\operatorname{Ig} M$ & - & - & 4,1 \\
\hline$M 14-11$ & F12 (C1979) & $\operatorname{IgG} 2 \mathrm{~b}$ & - & - & 4,1 \\
\hline$M 14-16$ & F12 (C1979) & $\operatorname{Ig} M$ & - & - & 4,1 \\
\hline$M 14-17$ & F12 (C1979) & $\operatorname{Ig} M$ & - & - & 4,1 \\
\hline $20025-F 2 a$ & F12 (20025) & $\operatorname{IgG2b}$ & - & - & 5,0 \\
\hline
\end{tabular}

Determined as deseribed in Materials and Me thods.

$b$ Given as the logarith of the last reciprocat dilution of the MAb giving an $A 490$ of at least 0.50 .

- Purified from strain HBIOI (pANN921).

d Purified from witd tupe etratn.

e $F 7_{1}, E P_{2}$ E9, EII, $13,1 C$ and $1 \mathrm{~A}$ fimbriae the non-readive with the monoctonate.

- no reaction. 
WId type E. coll strains, all these MAbs were tested in a whole bacteria ELISA. Previously, we have described this method as a convenlent and senwitwe method for the determination of $P$ flmbrlae on wild type $\mathbb{E}$. coli with the ald of MAbs (de Ree et al., 1986a). All F8 MAbs reacted strongly, as expected, Wh the $\mathrm{FB}$ reference strain C1254 (Table 2). These M8 MAb recognized also the fimbrtae on the wild type straln SP7. The Fl2 MAbs, raised agalnst the $\mathrm{F} 12$ fimbiae from $\mathrm{C} 1979$, reacted with the $\mathrm{F} 12$ reference strain C1979 but not with C134. Strain C134 expresses F12 flmbriae and also F13, Fy and $1 \mathbb{C}$ flmbriae. The F12 MAb 20025-F2a, which was raised against the F12 flmbriae fron 20025 ( $=134$ ), reacted strongly with C134 and also with C1979. This F12 MAb recognized also the fimbriae on the stralns SP57 and SP 88 .

The three wild type stralns C1254, C1979 and C134 al1 showed MRHA of human erythrocytes. In a HA Inhibition test not one of the homologous MAbs could inhibit this MRHA.

\section{DISCUSSION}

Recently we described the production of MAbs against the $\mathbb{P}$ fimbriae $F 7_{1}$, F7, F9, F11 (de Ree et a1., 1985b) and F13 (= Pap) (de Ree et al., 1986b). In this report we describe the production of MAbs agalnst two other $P$ fimbriae: F8 and F12. The F8 fimbriae were purifled from the strain HBlOI carrying pANN921, which was cloned from the wild type strain 2980 (Hacker et a1., to be published). This strain belonges to serotype 0l8:k5 (Jann et al., 1981). The reference strain C1254 for F8 flmbrlae from orskov and prskov (1983) belongs to the 075: $\mathrm{K}$ - serotype. F8 fimbriae purified from strain $\mathrm{C} 1254$ and the straln HB101 carrying pANN921 showed one band with the same mol. welght in SDS-PAGE (FIg. 1, lane b, c). From this SDS-PAGE the mol. weight was determined as 20.000 dalton. Monoclonal antibodies (MAbs) were ralsed against the $F 8$ flmbriae purifted from the recombinant strain. These MAbs al1 reacted strongly in an ELISA with the F8 fimbriae from the strain HB 101-pANN921 and wh the F8 fimbrlae from C1254 (Table 1). No cross reaction was found with any other fimbriae tested In this fimbriae ELISA. From these results we conclude that these MAbs recognize an antigenic determinant which is only present on F8 fimbriae. However, it is not certain whether these F8 MAbs recognlze the same or different epltopes. Recent data from DNA sequenclng of varlous P fimbriae subunits (Baga et al., 1984, van Dle and Bergmans, 1984) and the use of synthetic peptides to identify the immunogenic 
epitopes of the Pap fimbriae (Schmidt et al., 1984) revealed that there are several pronounced antigenic determinants on $\mathrm{P}$ flubriac. So, it is possible that the F8 MAbs recognize different epitopes on F8 fimbriae.

MAbs against F12 flmbriae were raised against the F12 flmbriae purifled from the wild type strain C1979. This fimbriae preparation showed two bands in SDS-PAGE with both a mol. weight of approximately 18.000 dalton (Fig. 1 , lane e). The mol. weight of this F12 fimbriae preparation is in agreenent with the mol. weight of 18.200 dalton of F12 fimbriae calculated by Klemm et al. (1983) on the basis of the amino acid composition of the subunit. However, the F12 fimbriae preparation of Klemm et al. (1983) showed only one band in SDS-PAGE. These F12 fimbriae were, just like our F12, purified from the wild type strain C1979, but they used another puriflcation method. They grew, just like us, the C1979 strain on solid medium to suppress any potential capacity for producing type 1 fimbriae. So, the extra band in our 12 preparation is not caused by type 1 flmbriae, but probably caused by the different purification method used by us. Our Fl2 flmbriae preparation was also checked for type 1 fimbriae contamination in a fimbriae ELISA with anti type 1 fimbriae Mabs. With this method we were not able to demonstrate any contamination with type 1 fimbriae (data not shown).

The presence of two bands in the F12 fimbriae preparations is not surprising. Klemm et al. (1983) and orskov and orskov (1983) suggested already that the F12 fimbriae from 61979 contain two highly homologous flmbrial protelns, because crossed immuno electrophoresis showed that the fli fimbriae preclpitates in two lines positioned very close to each other. They were not defined as two different fimbriae, since it was not possible to separate them as two different antigens by application of antiserum in an intermediate gel in the crossed Immuno electrophoresis system (brskov and orskov, 1983).

By Western blotting and lmmunoprecipitation test we tried to find out to which of the two $\mathbb{F 1 2}$ bands our MAbs were reactive. However, the F12 Mabs precipltated the $F 12$ fimbriae very badly for unknown reasons (data not shown). Western blotting experiments alsio did not reveal to which of the two F12 bands the MAbs were directed. The negative reaction of the MAbs, ralsed against the F12 fimbriae from strain C1979, in western blotting was not surprising because we demonstrated recently that almost al1 MAbs which we produced against the varioug $P$ fimbriae only recognized an epitope on native flmbriae and not on denatured fimbriae (de Ree at al., 1985b). 


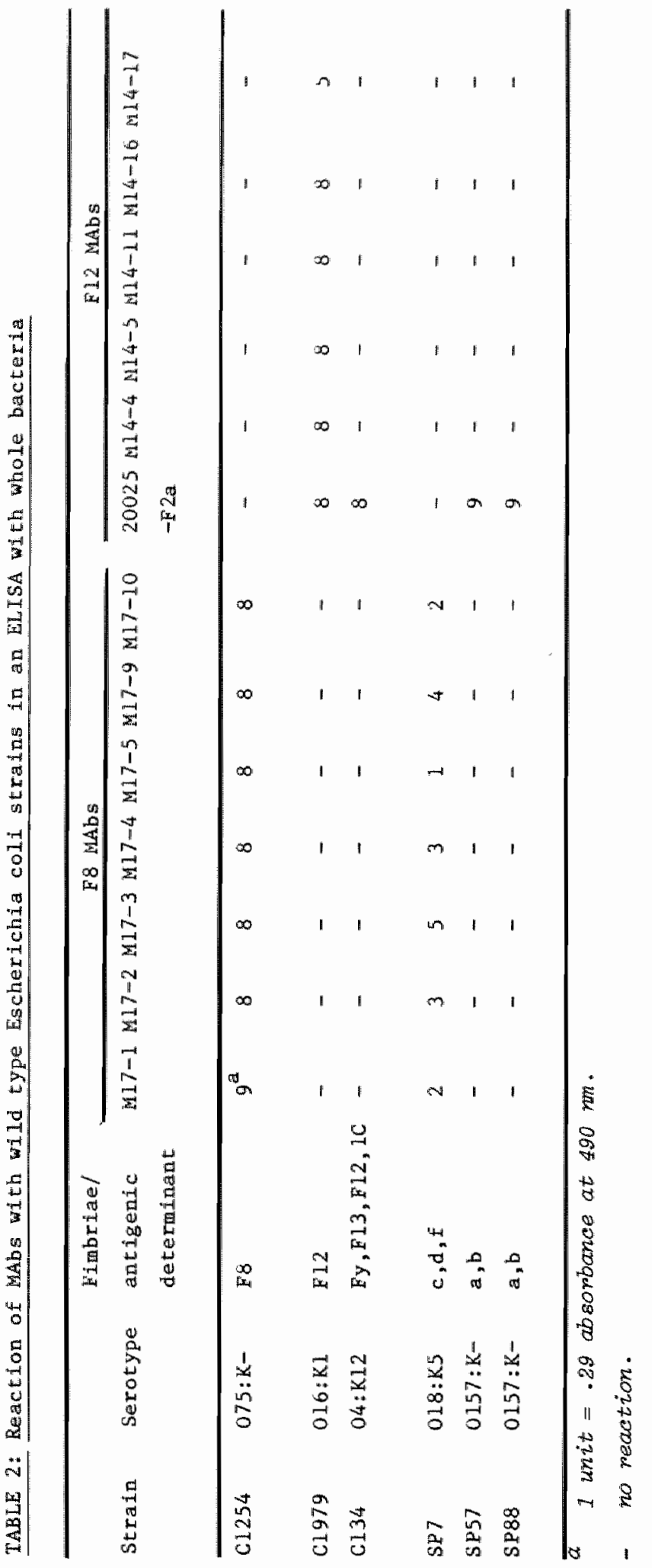


Aso from the whole bacteria ELISA it was demonstrated that strain C1979 expressed two F12 fimbriae. The F12 MAbs raised agalnst the F12 fimbriae from C1979 reacted only with the fimbriae on $\mathrm{C} 1979$, whereas the F12 MAb 20025-F2a which was raised against the 12 fimbriae from 20025 (C134), reacted whth the F12 fimbriae on C134 and also with the Fl2 fimbriae on C1979. So it is possible that the MAbs raised agalnst the Fl2 fimbriae from C1979 recognize one type of F12 fimbriae, whereas the 12 MAb which was raised against the F12 fimbriae from 20025 ( $=$ C134) recognlze another type of Fl2 fimbritae.

The F 12 MAb 20025-F2a raised against the F12 fimbriae from 20025 reacted also strongly with the fimbriae of the strains SPS7 and SP83, both with the serotype 0157:K-. All the F8 MAbs recognized in the whole bacteria ELISA the fimbriae on the SP7 strain with the serotype 018:K5. The F8 fimbriae are almost in all cases associated with the 018 or the 075 serotype ( Or skow, 1983).

The HA Inhibition assay revealed that the epltopes recognized by the F8 and F12 MAbs are not involved in adhesion, because not one of the homologous MAbs did inhibit the MRHA of the strains C1979 or HBl01 carrying plasmid pANN921. This means that these MAbs recognize an eptope on the fimbriae which is not involved in adhesion to uroepithelial cells.

With these FB and F12 MAbs we have extended our MAb collection agatnst the serologically different $P$ fimbriae of uropathogenle E. coll. These MAbs w11 be used for epidemlological studies on the distribution of $p$ fimbriae among uropathogenic E. coli.

\section{REFERENCES}

Baga, M., Normark, S., Eardy, J., O"Hanley, P., Lark, D, OLsson, O., Schoolnik, G, and Falkow, S. 1984. Nucleotlde sequence of the papA gene encoding the papA pilus subuntt of human aropathogenic Escherichia coll. - J. Bacteriol. 157: 330-333.

Boyer, H.W., Roulland-Dussoix D. 1969. A complementation analysils of the restriction and modification of DNA in Eschertchia col1. - J. Mol. B1ol. 41: $459-472$.

de kee, J.M., Schwillens, P., Promes, L., van DHe, I., Bergmans, H., and van den Bosch, J.F. 1985a. Molecular cloning and characterlzation of F9 fimbriae from a uropathogenic Escherichla col1. - FEMS Mlcroblo1. Lett. 26: $163-169$. 
de Ree, J.H., Schwllens, P., and van den Bosch, J.E. 1985b. Monoclonal antibodies that recognize the Pimbiae $F 7_{1}, F 7_{2}, F 9$ and $F 11$ from uropathogenle Escherlchia coli " Infect. Immun. 50: 900-904.

de Ree, J.H., Schwillens, $\mathbb{P}_{*}$, and van den Bosch, J.F. 1986a. Monoclonall antlbodies for serotyplng the $P$ firbrlae of uropathogenic Escherlchia col1. - J. C11n. Microblo1. 24: 121-125.

de Ree, J.M., Schwllens, P., and wan den Bosch, J.F. 1986b Monoclonal antibodies ralsed agalnst Pap fimbriae recognize minor component(s) involved In receptor binding. - Microblal Pathogenesis, in press.

Hagberg, L *, Jodal, U., Korhonen, T.K., Lidin-Janson, G, Lindberg, U., and Svanborg-Edén, C. 1981. Adhesion, hemagglutination, and virulence of Escherichid coli causing urinary tract infection. - Infect. Immun. 31 : $364-570$.

Jamn, K., Jann, B., and Schmidt, G. 1981. SDS-polyacrylamide gel electrophoresis and serological analysis of pili from Escherichia colt of different pathogenic origin. - HEMS Microbiol. Lett. 11: 21-25.

Klemm, P., Orskov, I., and Orskov, F. 1983. Isolation and characterization of F12 adhestve fimbrial antigen from uropathogenic Escherichia coli strains. - Infect. Immun. 40: 91-96.

Korhonen, T.K., Nurmtaho, E., Ranta, H., and Svanborg-Edén, C. 1980. New method for isolation of immunologically pure pill from Escherichia coli. - Infect. Immun. 27: 569-575.

Leffler, H., and Svanborg-Edén, C. 1980. Chemical identification of a glycosphingolipid receptor for Escherichia coli attachlng to human urinary tract epthellal cells and agglutinating human erythrocytes. - FEMS Microbiol. Lett. 8: 127-134.

Lugtenberg, B., Meyers, J., Peters, R., wan den Holek, P., and wan Alphen, L. 1975. Electrophoretlc resolution of the major outer membrane protelns of Escherichia col1 K12 1 nto four bands. - FEBS Lett.: 254-258.

trokov, I., and Drskov, F. 1983. Serology of Escherichia coli fimbriae. Prog. Allergy 33: 80-105.

Parry, S.H., Abraham, S.N., and Sussman, M. 1982. The biological and seroloBlical properties of adhesion determinants of Escherichla coll isolated from urinary tract Infections. p. 113-126. In: Schulte-wisserman (ed.) clinical, bacterlologlcal and immunological aspects of urinary tract infections in children. - Georg Thieme Verlag, Stuttgart. 
Schmidt, M.A., 0'Hanley, F., and Schoolnik, G.P. 1984. Ga1-Gal pyelonephritis Escherichia coli linear imunogenic and antigenic epltopes. - $J$. Exp. Med. 161: $705-717$.

Valsämen, V., Elo, J., Tallgren, L.G., Slltonen, A., Makeld, P.H., Svanborg-Edén, C., Kälenius, G., Svenson, S.B., Hultberg, H., and Korhonen, T.K. 1981. Mamnose-resistant haemagglutination and p-antigen recognition are characteristic of Escherichla coll causing primary pyelonephritis. - Lancet 1i: 1366-1369.

van den Bosch, J.F., Verboom-Sohmer, U., Postma, P., de Craaff, J., and MacLaren, D.M. 1980. Mannose-sensitive and mannose-resistant adherence to human uroepithelial cells and urinary virulence of Escherichia coli. Infect. Immun. 29: 226-233.

van den Bosch, J.F., Postma, P., Koopman, P.A.R., de Graaf, J., and Maclaren, D.M. 1982. Virulence of urinary and faecal Escherichia coll in relation to serotype, haemolysis and haemagglutination. - J. Hyg. 88: $567-577$.

van Die, I., and Bergmans, H. 1984. Nucleotide sequence of the gene encoding the $\mathrm{F}_{2}$ fimbrial subunit of a uropathogenic Escherichia coli strain. Gene 32: 83-90. 
MONOCLOMAL ANTBODIES RAISED AGAINST PAP ITMERTAE RECOGHIZE MINOR COMPOWEWI(S) INWOLVED IN RECEPTOR BINDING

\section{INTRODUCT ION}

The adherence of uropathogenic bacteria to uroepithelial cells is an important virulence factor. Adherence is mediated by fimbriae, also called p11. These fimbriae are heterogenous serologically $(1,2)$ as well as in the molecular weight of their subunit proteins $(3,4)$. According to their receptor structure, uropathogenic Escherichia coli fimbriae have been classified by their ablity to show a mannose sensitive (MS) or a mannose resistant haemagglutination (MRHA) of erythrocytes. The group of MR fimbriae can be subdivided into four groups: 1 the $\mathrm{P}$ fimbriae (also called Ga1-Gall fimbriae $(5,6))$, i1 the M Imbrlae (7), ill the S fimbriae (8) and iv the X fimbriae. The receptor structure of the first three groups is cleared up whereas this structure is unknown for the X flmbrlae.

Among uropathogenic E. coli especially the P fimbriae have been associated with pyelonephritis (9). These $P$ fimbriae function by binding epithelial glycosphingolipids of the urinary tract containing the globoside $\alpha-\mathrm{D}-\mathrm{Ga} 1 \underline{p}-(\mathrm{I}-4)-\beta-\mathrm{D}-\mathrm{GaI}$, which is the minimal receptor structure (5).

'The genes encoding for various $P$ fimbriae have recently been cloned $(10-17)$, as well as for the MS $(10,18)$ and $X$ fimbriae (19). The best studied gene clister 1 s the one which encodes for Pap fimbriae (10,20-23). Analysis of the gene organization of this gene cluster showed that at least eight polypeptides were involved in the blogenesis of globoside binding Pap fimbriae (20). Mutation experiments demonstrated that the papA gene encodes for the flabrillin subunit and that a mutation in the papA gene does not abolish the globoside binding (22). The papF and papg gene products are both required for globoside binding of whole bacterla and for HA by purified fimbriae (22). The papE gene product plays probably a role in the anchoring of the adhesin 
at the flmbriae (22), whereas the papc and papl gene products presumably are involved in the surface localisation and the polymerization of the fimbriae subunits and expression of fimbriae and globoside binding (23).

Fimbriae preparations from a cloned strain with an intact whole gene cluster for Pap fimbriae and globoside binding still show these binding properties $(22,24)$. Recently, Lindberg et al. (25) have shown that purifled Pap fimbriae contaim the proteins encoded by papE and papF. Antisera against purified Pap fimbriae contained also PapE and Papl specific antibodies. It was also demonstrated for the gene clusters of other $\mathbb{P}$ fimbriae, pPIL110-75 $\left(F 7_{1}\right)$, pPIL110-37 (F7 $)$, pPIL288-10 (F9), pPLL29l-15 (FI1) (26) and for pDCl (Clegg fimbriae) (27), that the fimbriae subunit is not required for the expression of the globoside specific adhesin. Also for the MS fimbriae (28) and for the $X$ fimbriae (19) it was demonstrated that fimbrlae expression and adhesion could be separated genetically.

Previously, we have described the production of monoclonal antibodies (MAbs) against the $P$ fimbriae $F 7_{1}, F 7_{2}, F 9$ and $F 11$ (4). In this study we describe the production of MAbs against Pap fimbriae. These fimbriae were recently also classified as F13 fimbriae (27). Here we demonstrate that some MAbs recognize Pap fimbriae but other MAbs recognize one of the minor components which are responstble for globoside binding.

\section{MATERIALS AND METHODS}

\section{Bacterial strains}

The E. coli strain J96 (04:K5) is a human pyelonephritis isolate and expresses simultaneousiy type 1 and $P$ fimbriae (PapmF13) (10). The construction of the strains HBlOL harboring pRHU845, pPAP5, or pPAP23 is described by Normark et $\mathrm{al}$. (20) and Lindberg et al. (22). On the plasmids pR4U445 and PPAP5 the whole gene cluster is present for expression of pap fimbrlae and globoside-speciflc binding. Plasmid pPAP23 contains also the whole gene cluster, but is mutated into the papA gene, and encodes for digalactoside specific binding but not for Pap fimbrlae. All these strains and plasmids were kindly provided by Bjơn Lund. The strains AM1727 harboring pPIL110-37 or pPlL291-15 encoding for galactoside binding and F7, and Fll fimbriae, respectively, were recently described (13, 15). Plasmid pPIL291-152 contalns also the whole gene cluster except that this plasmid is deleted into the Fil fimbrillin gene (26). This plasmid still encodes for globoside binding. The 
plagidds pEILL10-37 and pPIL291-152 were kindly provided by Irma van Die. A 11727 (13) and $\mathrm{HB} 101$ (33) are $\mathrm{E}$. coll K12 strains deficient in the production of type 1 tilmbriae.

All bacteria were cultivated on brain heart infusion agar (oxold Ltd.). Selective pressure against loss of plasmids was imposed by adding $50 \mathrm{pg} / \mathrm{ml}$ ample1111n or $12,3 \mu g / m i$ tetracycline, dependent on the cloning vector used.

\section{Purification of Elmbriae}

Fimbriae were purlfied by the method of Korhonen et a1. ( 34 ) avoiding protein denaturing conditions (14). Protein concentrations were measured by the method of Lowry et a1. (35). Purity of fimbriae preparations was checked by sodium dodecyl. sulphate-polyacrylamide gel electrophoresis (SDS-PAGE) (36). Gels were loaded with $30 \mu \mathrm{g}$ of fimbriae and stained with Coomassle Brilliant EItue. Pap fimbriae were purifled from strain AM1727 harboring pRHU845. The $F 7_{1}, 27_{2}, F 9, F 11, C l e g g, 1 A$ and $1 C$ fimbriae were all purified from strains with cloned fimbriae (4), whereas the F8 and E12 fimbriae were purified from the wild type stralns $\mathrm{C}_{12} 254(075: \mathrm{K}-)$ and $\mathrm{Cl} 979$ (016:K1) (1), respectively.

\section{Bybridoma production}

Monoclonal anttbadies (MAbs) against Pap flmbriae were produced as described recently (4). Brlefly, a BALB/c mouse was injected intravenously several times with Pap fimbriae. The spleen cells were fused with cells from the nonproducling myeloma cell line SP2/0. After 3 weeks hybridome cells were cested for anti fimbriae production in an enzyme-linked immunasorbent assay (ELISA). Positive clones were subcloned by a limiting dilution step and grown up for antibody production in ascitic fluid. Antibodies were partially purtried from ascitic fluld as described (4).

The MAbs $M 7-5$ and $M 7-15$, raised against 11 fimbriae previously, react wth the fimbriae Fl1, F7, and Pap (4).

ELISA for ant1 flmbrlal antibody determination

An ELISA with purtfied cloned fimbriae was carried out essentially as deseribed (4). Briefly, citcratiterplates (polyvinylchloride, Flow) were coated with purifled fimbriae, followed by incubation with serfal dilutions of MAbs. Anti-fimbriae activity was detected colorimetrically after incubation with goat anti-mouse antiserum, conjugated with peroxidase (Nordic) 
and addition of the substrate o-phenylenediamine (Sigma). Absorbance at 495 nm was determined with a Titertek multiscan ELISA plate reader.

Whole bacteria ELISA

An ELISA with whole bacteria as antigen was carried out as recently described (32). Briefly, bacteria were coated to microtiterplates and preincubated with New Born Calf Serum (Gibco Laboratories), followed by an incubation with serial dilutions of MAbs. Anti-fimbriae activity was detected as described above.

Class determination of MAbs

Microtiterplates were coated with flmbriae and homologous MAbs were added as described for the fimbriae ELISA. Goat anti-mouse IgGl, IgG2a, IgG2b or IgM (NordIc) was added as the second antibody. MAb classes were detected after the addition of rabbit anti-goat $\operatorname{IgG}$ (heavy and 1 ight chaims) conjugated to peroxidase (Nordic).

Adherence to human uroepithelial cell line T24

The human uroeplthelial ce11 line T24 was kindly supplied by Bjorn Lund. Adherence experiments were carried out essentially as described by B. Uhlin et al. (23). Briefly, non confluent layers of $\mathbb{T} 24$ cells in plastic petri dishes were obtained by culturing the cells for $24 \mathrm{~h}$. Bacteria $\left(2 \times 10^{8}\right.$ per dishj were added and allowed to attach for 1 h at $37^{\circ} \mathrm{C}$. After this incubation T24 cells were washed with sallne $(5 x)$ and stained with $30 \%$ filtered Gllemsa stain (Merck). Adherence was examined with a light microscope and expressed. as the percentage of $\mathrm{T} 24$ cells with at least 25 adherent bacteria out of a total of 100 cells counted.

\section{MRHA assays}

The MRHA activity of bacterial stralns with tuman erythrocytes and the inhibition of HA were determined by the method of Van den Bosch et a1. (37). Briefly, serlal dilutions of bacteria were incubated with human erythrocytes for $2 \mathrm{~h}$ on 1ce. HA was read after agitation. The inhibition of HA was tested with bacteria preincubated for $30 \mathrm{~min}$ at room temperature with MAbs. Antibody dilutions which did not cause agglutination of bacterla, as checked by micrascopy, were used. 
Lectron ficroscopy wa carried out a described by van den Bosch et al. (38). Hacterla were grown overnight and resuspended in PBS containing 0,25\% formalin. After 1 h flxation arop of the bacterial suspension was placed on a Formar coated copper grid and allowed to stand for 15 min. Excess suspension was drained off, and the adherent bacteria were negatively stained with $1 \%$ phosphotungtic acid ph 7.0 for $15 \mathrm{~s}$.

V1sualisation of immune complexes was performed as follows. A drop of a bacterlal suspension was placed on a grid and allowed to dry "The grid was Incubated th sultable dilution of a MAb for $1 \mathrm{~h}$ and thoroughly washed wth saline solution containing $0,5 \%$ bovine serum albumin and $0,1 \%$ gelatine. Subsequently the grids were incubated with gold labeled protein $A$ for 1 h. The grids were extensively washed and negatively stained with $1 \%$ phosphotungstle acld. The protein A labeled with the gold particles was kindly supplied by Nico Riegman.

Spottest for the reaction of Mabs wh denatured fimbriae

A spottest for the reaction of the MAbs with denatured fimbriae was carrled out as described (4). Briefly, fimbriae were denatured by bolling in a buffer containing beta-mercaptoethanol and SDS. Denatured fimbriae were spotted on nitrocellulose paper and incubated with the MAbs. Imune complexes were detected by incubation with goat anti-mouse peroxidase conjugate and diaminobenzlde as substrate. The reaction was developed in the dark and terminated wil th $\mathrm{H}_{2} \mathrm{SO}_{4}$.

\section{RESULTS}

MAb production and charactertzation

Pap flwbriae were purifled from strain AM1727 harboring pRHU845 and were show to be pure in SDS-PAGE (4). Purlfled Pap flmbriae were used for MAb production as described. Three weeks after the fuston of spleen cells and SP2/0 myelona cells, the hybridomas with the highest titer in a fimbriae ELISA were selected for additional growth. After subcloning the hybridomas were grown up and used for the production of ascltic fluld. MAbs were partially purified from these ascitic fluids and tested in a fimbriae ELISA for (cross)-reactions with varlous purifled fimbriae. The titers of the MAbs against homologous and heterologous flubriae are show in Table 1 . With 
TABLE 1: Titer of MAbs in an ELISA with different purifled fimbriae and subclasses of antibodles

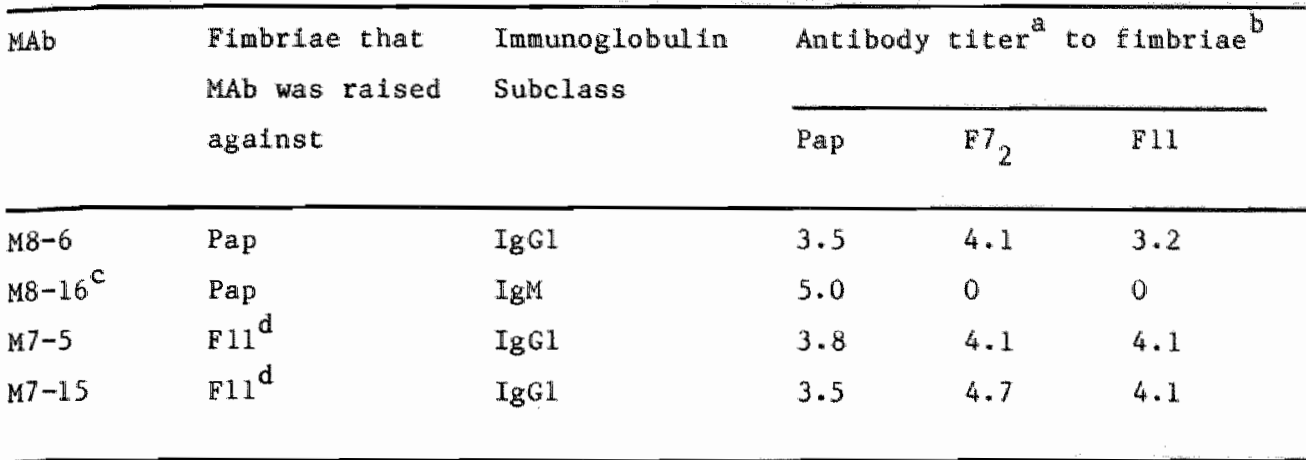

a Given as the Logarith of the Last reciprocal dilution of the antiaenum given an $A 490$ of at least 0.50 .

b $F 7, F 8, F 9, F 12, C l e g g, 14$ and $1 C$ fimbriae were nonreact ive.

c Four other $M A B$ s showed an identical reaction.

a Rejerence 4.

regard to the M8 MAbs raised agalnst Pap fimbriae, only the M8-6 MAb reacted with an epitope on Pap, F7, and Fll fimbriae. Five other MAbs which were raised against Pap fimbriae only recognized an epitope on Pap fimbrlae. The M7-5 and M7-15 MAbs, which were raised against FLl previously (4), showed the same cross reaction as the M8-6 MAb in the fimbriae ELISA. Al1 M8 MAbs were of the IgM subclass except M8-6. This MAb belongs, just IIke the M7-5 and M7-15 MAb, to the IgGl subclass.

In an ELISA with whole bacterla as an antigen, all MB and the M7-5 and M7-15 MAbs reacted with the strains $\$ 96$ and HB101 harboring pPAP5. (Table 2 ). The M8-6, M7-5 and M7-15 MAbs did also react with the straln AM1727 harboring pPIL110-37 or PPIL291-15 encoding for digalactos1de binding and 72 or 11 . fimbriae, respectively. To find out whether these $M 8, M 7-5$ and $M 7-15 \mathrm{MAbs} d 1 \mathrm{~d}$ recognize the fimbriae or the minot components on the fimbriae responstble for the digalactoside binding, these MAbs were also tested in the whole bacteria ELISA with the strains HB101-pPAP23 and AM1727-pPIL291-152. Both stralns encode for digalactoside binding but do not express Pap or Fll flmbrlae, respectively. Surprisingly the M8-6, M7-5 and M7-15 MAbs reacted 
TABLE 2: Ttex ${ }^{a}$ of monoclonal antlbodies in a whole bacteria ELISA

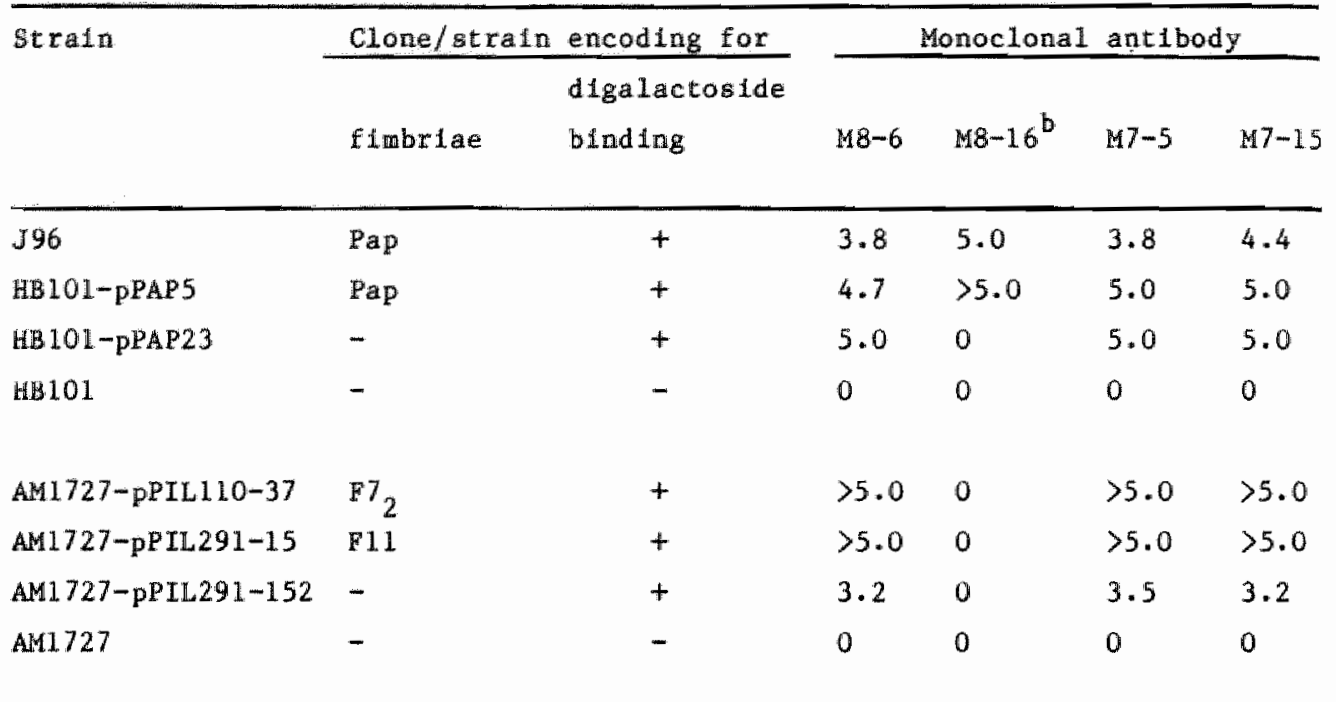

$a$ See footnote ${ }^{a}$ in Table 1.
$b$ See footnote ${ }^{a}$ in Table 1.

strongly with these strains (Table 2). This suggests that these MAbs recognize one of the minor components responstble for digalactoside binding * The control strains HB101 and AM1727 did not react with any MAb in this whole bacteria ELIISA.

The M8 MAbs were also tested for their abllity to recognize an epltope on denatured fimbriae. In a spottest all M8 MAbs did not react with the denatured Pap fimbriae, whereas they were reactive with native pap fimbriae. Western blotelng experiments also showed that not one of the M8 MAbs did react wh denatured fimbriae (data not shown).

\section{HA and Adherence Inthibition assays}

The MRHA titer of the strains HB101 harboring PPAP23 and AM1727 harboring pPIL291-152 was total1y inhibited in the presence of the M8-6, M7-5 or M7-15 MAbs (Table 3). The M8-16 MAb did not inhibit the MRHA of these strains. 
TABLE 3: Adherence to T24 cells and MRHA with human erythrocytes of the stralns HB1O1-pPAP23 and AM1727-pPIL291-152, and 1nhib1tion by monoclonal antibodies

\begin{tabular}{lccccc}
\hline & \multicolumn{5}{c}{ MRHA titer } \\
\cline { 2 - 6 } Strain & - & \multicolumn{3}{c}{ In the presence of } \\
\cline { 2 - 6 } & & M8-6 & M7-5 & M7-15 & M8-16 \\
\hline HB101-pPAP23 & 32 & 0 & 0 & 0 & 32 \\
AM1727-pPIL291-152 & 16 & 0 & 0 & 0 & 16 \\
HB101 & 0 & - & - & - & - \\
AM1727 & 0 & - & - & - & -
\end{tabular}

Strain

Adherence to $T 24$ uroepl the 11 al $\operatorname{cells}^{\mathrm{a}}$

\begin{tabular}{|c|c|c|c|}
\hline \multirow[t]{2}{*}{ _ } & In the & ce of & \\
\hline & $M 8-6$ & $47-15$ & $M 8-16$ \\
\hline
\end{tabular}

\begin{tabular}{lccccc}
\hline HB101-pPAP23 & $79 \pm 7^{b}$ & $6 \pm 3$ & $6 \pm 1$ & $10 \pm 9$ & $88 \pm 11$ \\
AM1727-pPIL291-152 & $85 \pm 7$ & $29 \pm 7$ & $30 \pm 9$ & $6 \pm 3$ & $85 \pm 3$ \\
HB101 & 0 & - & - & - & - \\
AM1727 & 0 & - & - & - & -
\end{tabular}

a Adherence was determined in the presence of $1 \%$-momose and expressed as the percentage of $T 24$ cells with at least 25 adherent bacteria out of a totat of 100 cells counted.

$b$ Eigures in the adherence aseay are presented as mean values + standand deviation.

These results corresponded th the results of the adherence assay using the urinary epthelilal cell line T24. The adherence of the stralns HBl01 harboring PPAP2 3 and AM1727 harboring pPIL291-152 was also strongly inh1b1ted in the presence of the MAbs M8-6, M7-5 and M7-15, whereas M8-16 did not show any inhibition in this assay (Table 3 ). 
Pig. 1: Immino eLectron microscopy with MABs and HB101 with pPAPS or pPAP23.

a. BB101 harboring PPAP5 with M8-16

b. HB101 hamboring PPAPS with $M B-6$

c. HB101 harboring PPAPS with M7-6, a MAD specific for al1 fimbriae fimbriale (4)
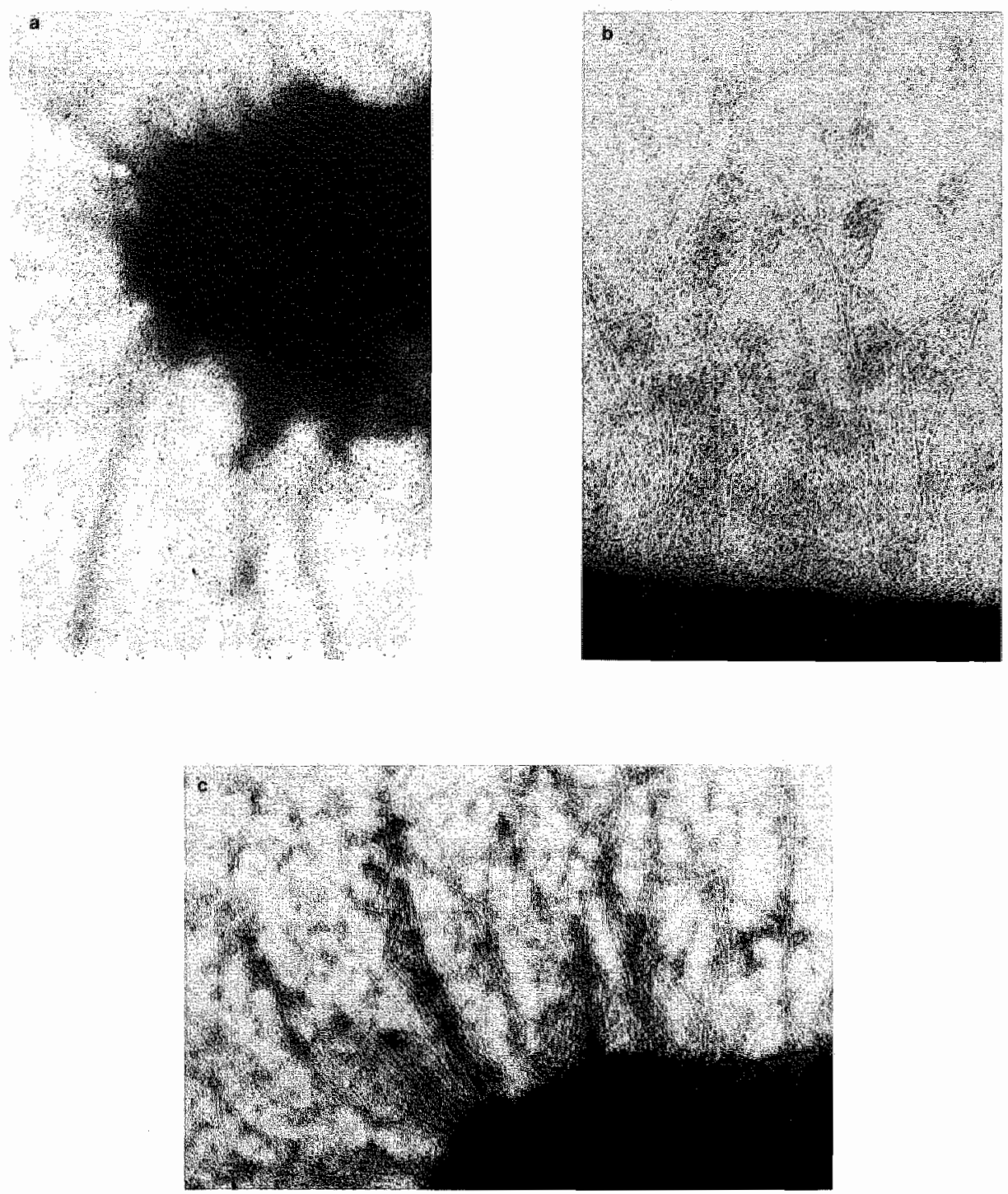

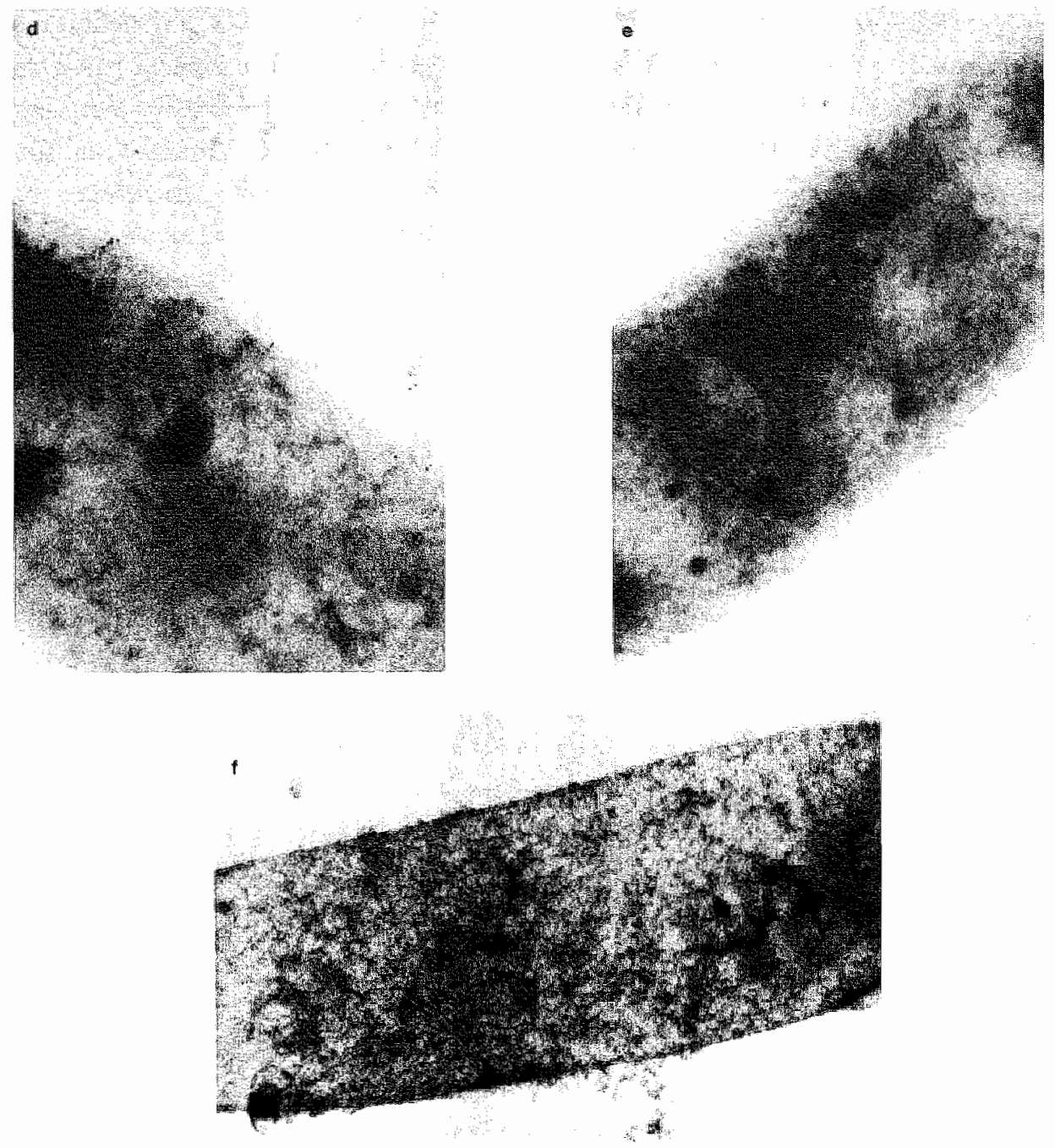

Fig. 1: Immuno electron microscopy with MAbs and HB101 with PPAP5 or pPAP23.

d. HB101 harboring PPAP23 with M8-6

e. HB101 harboring PPAP23 with M8-16

f. HB101 with $M 8-6$ 
Wh 1 Guno lectron lecoscopy 1 thas demonstrated that the M8-16 MAb Btrongly reacted with the fimbriae of the strain HBLOI harboring pPAPS (Fiy. La). All the other M8-MAbs, except M8-6, showed the same reaction in immuno electronmicroscopy. The $4-6, M 7-5$ and $M 7-15$ reacted again similarly. These three MAbs did not react with the flmbriae but they reacted with components which were found between the flubrlae (Fig. Ib). As a negative control an irrelevant antibody (M7-6 which 1 s 11 fimbriae specific) was added to HB101 harboring pPAP5. No reaction of this antibody could be detected (Fig. $1 \mathrm{c}$ ). The M8-6, M7-5 and M7-15 MAbs also showed a reaction with a component present on the gurface of the strain HB101 harboring pPAP23 (F1g. Id), whereas no such reaction with this strain was found with the other M8-MAbs (Fig. 1 e). The M8-6 MAb showed also no reaction wh the strain HBIO1 (FIg. If).

\section{DISCUSSION}

In this study we described the production of monoclonal antibodies (MAbs) agalnst Pap finbriae which were purified from strain AM1727 harboring pRHU845. Five MAbs raised against Pap flmbriae recognized only an epitope on Pap fimbriae. However, one MAb (M8-6) recognized also an epitope on $F 7_{2}$ and Fll fimbriae. An 1dentical reaction as for $M 8-6$ was previously described for the F11 MAbs M7-5 and M7-15, which also recognized $F 7_{2}$, F11 and Pap fimbriae (4). Thus it is very likely that these MAbs recognize an identical epitope which 1 s present on $\mathrm{FT}_{2}, \mathrm{~F} 11$ and Pap fimbriae.

In a whole bacterla ELISA all M8 MAbs did react with the strains J96, HB101 harboring pPAP5 and AM1727 harboring pRHU845 (Table 2). Surprisingly, the M8-6, M7-5 and M7-15 MAbs also reacted strongly with the strain HB101 harboring pPAP23 and also with AM1727 harbor1ng pPIL291-152 (Table 2). These last two stralns do not express Pap or F11 fimbriae, respectively, but st11 encode for globoside binding $(22,26)$. pPAP23 constructed by a frameshift mutation into the papA structural gene, whereas pPIL291-152 was constructed by a deletion of pPLL291-15 lacking the gene encoding for the fimbrillin subunit. This means that these MAbs recognize an epitope on the minor components of the fimbrlae which are responsible for globoside blinding. This is supported by the finding that the MAbs M8-6, M7-5 and M7-15 inhibited completely the MRHA of the strains HB101-pPAP23 and AM1727-pPIL291-152 as well as the adherence to $T 24$ uroepithellal cells (Table 3 ). The Pap fimbriae 
speciflc MAb M8-16, however, did not show any Inhibtion of MRHA and adherence. Furthermore, the immono electron microscopy results demonstrated that the three MAbs MB-6, M7-5 and M7-15 reacted with a surface component on the strain HB101 harboring pPAP23 (Fig. Ld) and not with the fimbriae on strain HB 101 harboring pPAPS (Fig. $1 \mathrm{~b}$ ). The specific and strong reaction of the other M8-MAbs with the Pap fimbriae on strain HB101 harboring pPAPS (Fig. 1a) was also different from the reaction of the M8-6 MAb wh this strain. From these results we conclude that the M-6, M7-5 and M7-15 MAbs react with a minor component responsible for adhesion, whereas the other MAbs react with the Pap fimbriae. These results are in agreement with the results of Lindberg et al. (25) who demonstrated that PapE and Papl are surface exposed on a papA mutant.

Lund et al. have compared the genes which encode for the minor adhesive components, from the Pap, $F 7_{2}$ and PDC5 gene cluster (27). They showed that the papE and papF genes were conserved in these three gene clusters. The papG variant in the $F_{2}$ and $P D C 5$ gene clusters were very similar, but unique for the Pap gene cluster. pDC5 is a subclone from pDCl and encodes only for globoside binding. pDCl encodes for Clegg fimbriae (11) and for globoside binding * Kecently we have shown that Clegg and Fll flmbrlae are serologlcal identlcal and that they have the same mol welight (4). The Clegg fimbriae were also typed as FII in cross-immunoelectrophoresis by $I$, and F. Mrskow (personal communication). The similarities between the F11 and Clegg fimbriae would suggest that the two gene clusters have much homology. However, the MAbs MB-6, M7-5 and $M 7-15$ did not recognize an epitope on the clegg fimbriae. So probably the minor components of Clegg and Fll flmbriae are different.

Gonococcal fimbriae undergo an extensive antigenic variation to circumvent the limune response (29). The variation in these fimbriae probably occurs in a domaln which is different from the region required for polymerization and receptor-specific interaction $(30,31)$. All the MAbs against $p$ fimbriae whllch were isolated by us were produced by sicreening for the highest anti fimbriae titer in an ELISA. Almost all MAbs were specific for the flmbriae which they were ralsed against $(4,32$, this study), but the adhesin specific MAbs showed a cross reaction with three different fimbriae. This suggests that the most pronounced antigenic structures on $\mathrm{P}$ fimbriae undergo an extensive antigenic variation, like for gonococcal fimbriae, whereas the minor components responsible for adhesion have a more conservative structure. 
The present results and the results from the genetic studies on the minor components of fimbriae from lund et all. (27) indicate that the development of a posible vaccine has to be concentrated on the winor adhesive components rather than on the flmbrlae component. The MAbs which recognize one of the minox components, as shown in this study, could be helpful for the purifleation and characterization of these proteins.

\section{MEE ERENCES}

1. Orkov I, and orskov F. The serology of Escherichia coli fimbriae. Progr Allergy 1983; 33: 80-105.

2. Parry SH, Abraham SN, and Sussman M. The biological and serological properties of adhesion determinants of Escherichia coll isolated from urinary tract infections. In: H. Schulte-Wisserman, ed. Clinical, Bacterological and Immunologlcal Aspects of Urinary Tract Infections in Children. Georg Thieme Verlag, Stuttgart 1982; 113-126.

3. Jann $K$, Jann B, and Schmidt G. SDS-polyacrylamide gel electrophoresis and serological analysis of pill from Escherichia coll of different pathogenic origin. FEMS Microblol. Lett. 1981; 1:: 21-25.

4. De Ree JM, Schwillens P, and van den Bosch JF. Monoclonal antibodies that recognize the $\mathrm{P}$ fimbriae $F 7_{1}, F 7_{2}, F 9$ and $F 11$ from uropathogenic Escherichia coll. Infect. Immun. 1985; 50:900-904.

5. Leffler $H$, and Svanborg-Edén $C$. Chemlcal Identification of a glycosphingolipld receptor for Escherichia coli attaching to hum urinary tract epithellal cells and agglutinating human erythrocytes. FEMS Micrabiol. Lett. $1980 ; 8: 127-134$.

6. KALlenlus $G$, Mollby $R$, Swenson SB, Wlinberg J, Lundblad A, Svenson $S$, and Cedergren B. The $p^{k}$ antigen as receptor for the hemagglutination of pyelonephritogenic Escherichia col1. FEMS Mierbiol. Lett. 1980; 7: 297.

7. Valianen $V$, Korhonen TK, Jokinen M, Gahmberg CG, and Ehnholm C. Blood group $M$ speciflc haemagglutinin in pyelonephritogentc Escherichia coli. Lancet $1982 ; 1: 1192$.

8. Korhonen TK, Vaisanen-Rhen V, Rhen $M$, Porc $A$, Parkkinen J, and Finne J. Eschertchia coll fimbriae recognizing sialyl galactasides. J. Bacteriol. $1984 ; 159: 762-766$. 
9. Väisänen V, Elo J, Tallgren LG, Siltonen A, Makela PH, Svanborg-kiden C, Kallenius G, Svension SB, Hultberg $H$, and Korhonen TK. Manose-reststant haemagglutination and $\mathbb{P}$-antigen recognition are characteristic of Escherichia coli causing primary pyelonephritis. Lancet 1981; ii: 1366-1369.

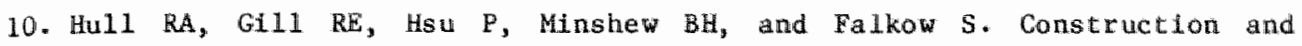
expression of recombinant plasmids encoding type 1 or D-mannose-resistant pill from a urinary tract infection Escherichia coll isolate. Infect. Immun. 1981; $33: 933-938$.

11. Clegg S. Cloning of genes determining the production of mannose resistant fimbriae in a uropathogenic strain of Escherichia coli belonging to serogroup 06. Infect. Imman. 1982; 38: 739-744.

12. Van Die I, Splerings G, van Megen I, Zuidweg E, Hoekstra W, and Bergmans H. Cloning and genetic organization of the gene cluster encoding Fl fimbriae of uropathogenic Escherlchid coli and comparison with the $\mathrm{F7}_{2}$ gene cluster. FEMS Microbiol. Lett. 1985; 28: 329-334.

13. Van Die $I$, wan den Hondel $C$, Hamstra $H$, Hoekstra $W$, and Bergmans $\mathbb{H}$. Studies on the f1mbrlae of an Escherichla coll 06:K2:H1:7 straln: molecular cloning of a DNA fragment encoding a fimbrial antigen responsible for mannose resistant haemagglutination of erythrocytes. FEMS Microblol. Lett. 1983; 29: 77-82.

14. De Ree JM, Schwllens P, Promes L, van Die I, Bergmans H, and van den Bosich JF. Molecular cloning and characterization of fo fimbriae from a uropathogenic Escherichia coli. FEMS Microbiol. Lett. 1985; 26: 163-169.

15. De Ree JM, Schwillens $P$, and van den Bosch JF. Molecular cloning of PII fimbriae from a uropathogentc Escherichia coli and characterization of flmbriae with polyclonal and monoclonal antibodies. FEMS MLcrobiol. Lett. $1985 ; 163-169$.

16. Rhen M, Knowks J, Pennt111d ME, Sarvas M, and Korhonen TK. P fimbrlae of Escherichia coli: Molecular cloning of DNA fragments containing the structura1 genes. FEMS Microblo1. Lett. 1983; 19: 119-123.

17. Low D, David V, Lark D, Schooln1k G, and Falkow S. Gene clusters governing the production of hemolysin and mannose-resistant hemagglutination are closely linked in Eschertchia coll serotype 04 and 06 isolates from urinary tract infection. Infect. Immun. 1984; 43: 353-358. 
18. Mlemm $P$, Jorgensen $B$, , van Die $I$, de kee H, and Bergmans H. The fim gene responsible for symthests of type 1 fimbriae in Escherichia cali, clonin and genetic organization. Mo1. Gen. Genet. 1985; 199:410-414.

19. Hacker $J$, schifd $G$, Hughes $C$, Knapp $S$, Marget M, and GoebeI W. CIonin and charactertzation of genes involved in production of mannose reslatant, neuraminidase-susceptible $(X)$ fimbriae fron a uropathogeni 06:KL5:H31 Lscherichia coli strain. Infec. Immun. 1985; $47: 434-440$.

20. Nornark $S$, Lark $D$, Hull $R$, horgren $M$, Baga $M$, O"Hanley $P$, Schoolnik $G$ and Falkow $s$. Genetics of digalactoside-bindlig adhesin from a uro" pathogenic Escherichia coli straln. Infect. Immun. 1983; 41:942-949.

2L. Norgren M, Normark S, Lark D, O'Hanley P, Schoolnik, G, Falkow $S$ Svanborg-Eden C, Baga $M$, and Uhlin BE. Mutations in E. coli cistron: affecting adhesion to human cells do not abolish pap pil1 fiber formation. EMBO Journal 1984; 3: 1159-1165.

22. Lindberg EP, Lund $B$, and Normark $S$. Genes of pyelonephritogenic E. coll required for digalactoside speciflic agglutination of human cells. EMbC Journal 1984; 3: 1167-1173.

23. Uh1 in BE, Norgren $M, B a g a M$, and Normark S. Adheston to human cells by Escherichia coll lacking the major subunt of a digalactoside-spectfic pilus adhestn. Proc. Nat1. Acad. Sci. U.S.A. 1985; 82: 1800-1804.

24. O'Hanley P, Lark D, Normark S, Falkow S, and Schoolnik GK. Mannose sensitive and Gal-Gal binding in Escherichia coli pill from recombinant strains. J. Exp. Med. 1983; 158: 1713-1719.

25. Lindberg $F$, Lund $B$, and Normark $S$. Gene products specifying adhesion of uropathogenic Escherichla col1 are minor components of pill. Proc. Natl. Acad. Sci. U.S.A. 1986; 83: 1891-1895.

26. Van Dle $I$, Zuldweg $\mathbb{E}$, Hoekstra $W$, and Bergmans $\mathbb{H}$. The role of fimbriae of uropathogentc Escherichia coli as carriers of the adhesin involved in mannose resistant hemagglutination. Microbiol. Pathogenesis 1986; 1 : in presa.

27. Lund $B$, Lindberg FP, Baga M, and Normark S. Globoside-spectfic adhesins of uropathogenic Eschertchia coli are encoded by similar trans-complementable gene clusters. J. Bact. 1985; 162: 1293-1301.

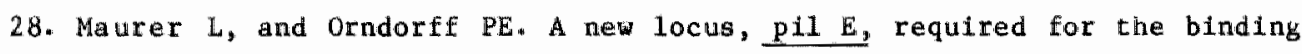
of Type 1 plliated Escherichia coll to erythrocytes. EEMS Microblol. Lett. 1985; 30: 59-66. 
29. Heyer TF, Mlawer M, and So R. Pilus expression in Neisseria gonorrhoese involves chromosomal rearrangement. Cell $1982 ; 30: 45-52$.

30. Rothbard JB, Fernandez R, and Schoolnik GK. Straln-specific and comon epitopes of gonococcal pili. J. Exp. Med. 1984; 160: 208-221.

31. Schoolnik GK, Fernandez R, Tal JY, Rothbard J, and Gothschlich EC. Gonococcal pili. Primary structure and receptor binding domaln. J. Bup. Med. 1984; 1591: 1351-1370.

32. De Ree JM, Schwillens $P$, and van den Bosch JF. Monoclonal antibodtes for serotyping the $P$ flmbriae of uropathogenic Escherichia coli. J. Clin. Microbio1. 1986; $24: 121-125$.

33. Boyer HW, and Roulland-Dussolx D. A complementation analysis of the restriction and modification of DNA in Escherichia coll. J. Mol. Bol. $1969 ; 41: 459-472$.

34. Korhonen $T K$, Nurmiaho $E$, Ranta $H$, and Svanborg-Eden $C$. New method for isolation of immunologically pure pili from Escherichia coll. Infec. Immun. 1980; $27: 569-575$.

35. Lowry OH, Rasebrough NJ, Farr AL, and Randa11 RJ. Protein measurement with the folln-phenol reagent. J. Biol. Chem. 1951; 193: 265-275.

36. Lugtenberg B, Meyers J, Peters $R$, wan den Hoek $P$, and van Alphen $L$. Electrophoretic resolution of the major outer membrane proteins of Escherich1a col1 $K 12$ into four bands. FEBS Lett. 1975; 58: 254-258.

37. Van den Bosch JF, Postma P, Koopman PAR, de Graaff J, and MacLaren DM. Virulence of urinary and faecal Escherichia coli in relation to serotype, haemolysis and haemagglutination. J. Hyg. 1982;88:567-577.

38. Van den Bosch JF, Verboom-Sohmer U, Postma $P$, de Graaff J, and MacLaren DM. Mannose-sensitive and mannose-resistant adherence to human uroepithelial cells and urinary virulence of Escherlchia coll. Infect. Immun. 1980; 29: 226-233. 
MONOCLONAL AWMTBODIES EOR SEROTYPIWG THE P FIMBRIAE OF

UHOPA THOGENTC BSCHERTCHIA COLI

The ability of uropathogenic Escherichia coll to adthere to uroepithelial cotls is an important wirulence factor 115,17 , 18), cnablimg these bacteria to circumwent the flushing action of arine and to infect the urinary tract. Adhesion is mediated by firmbrate which bind to specific cell surface recepter molecules. The majority of these wropathogenic $E$. coli strains express, P fimbrite (16), which recognize as a receptor structure the disaccharide $\alpha \cdot D \cdot G a l p p(1-4) \cdot \beta+D-G a l p$ (10) on the uroepithelial cells. "These $\mathrm{P}$ fimbritue differ in the molecular weights of their subunit proteins $(7)$ and in serological properties (12, 13). Qrskow and $\emptyset$ rskov (12) could distinguish eight serologically different fimbriae on wropsthogenic $E$. colt by using crossed-immunoelectrophoresis techniques. They suggested that these fimbriae be referred to as. antigens (F7 to $F 12$ ). This typing scheme of $P$ fimbriae was recently extended by the classification of pyelonephritis. associated pilus (Pap) fimbriae as F13 fimbriae (11). Parry et al. (13) were able to determine seven different antigenic determainants on fimbriae of uropathogenic $E$. coll by using a slide agglutination test and designated them a to g.

In both studies $(12,13)$ cross-absorbed polyclonal antisera were used. Recently, we described the production of monoclonal antibodies (MAbs) against the four different $P$ fimbriae $F 7_{\|}, F 7_{2}, F 9$, and FII (4). The main purpose of this study was to develop a rapid and easy method. with the aid of the MAbs, for the detection of serologically different P fimbriae on wild-type $d$. coli stans. Therefore, we compared three different methods: a plate agglutination test, a coagglutination test with Staphylococctes awases as a carrier for the MAbs, and an erizyme-linked immunosorbent assay (ELISA with whole bacteria as an antigen. A comparison of these three methods showed that the wholebacterium ELISA was the bes method for the screening of $P$ funbriat on uropathogenic E. coli.

\section{MATERIALSS ANID METHODS}

Bacterial strains, plasmids and growth media. The bacte rial strains and plasmids usied in this study are listed in Tabl 1. The C, SP, and J96 strains were kindly provided by 1 Griskov and F. Orskov, Steve Parry, and Björn Lund respectively. The $S^{\mathrm{P}}$ sitrains were serotyped by P.A.M Guimee (State Institute for Public Health, Bilthoven, Th Netherlands). Plasmids PPIL110-70 and PPILI10-37 wer kindly provided by Irma van Die, plasmid pRHU845 wa: provided by Staffan Normark. plasmid pDCl was provide by Steven Clegg, and plasmid pANN921 was provided b? Jorg Hacker. All the fimbriae encoded by these plasmids ar" $P$ fimbriae. AM1727 is a recA derivative of JE2571 an $E$. col K-12 strain deficient in the production of type 1 fimbriae (20) All wild-type strains were cullivated on blood agar plate (Oxoid Ltd.), and cloned strains were cultivated on brair heat infusion agar (Oxoid Lid.). Selective pressute agains the loss of plasmids was imposed by adding $50 \mu \mathrm{g}$ o ampicillin, $100 \mu \mathrm{\mu g}$ of chloramphenicol, or $12,5 \mu \mathrm{g}$ of tetra cycline per mul, depending on the cloning vector used.

MAbs againgt the $P$ fimbriae $F 7_{1}, F 7_{2}, F 8, F 9, F 11, F 12$, anc F13. The production of MAbs against the $P$ fimbriae $F 7_{1}$ $\mathrm{FP}_{2,} \mathrm{F9}$, and Fll was recemtly described (4). Briefly, spleen cells of immunized BALEB/C mice were fused with the myeloma celll line SP2/0, and the resuling hybridomats were grown for 3 weeks. Antbolly production agains fimbriae was tested in an ELISA, and positive clones were subcloned by a limiting dilution step. After adelitional growth, the cells were used for antibody production in ascitic fluid. MAbs were partially ptrified from ascitic fluid as described previotsly (4). For this study use used various MAbs against different $\mathbf{P}$ firnbrine, selected on the basis of specificity and immunoglobuin subciass. The characteristics of the MAbs used are shown in Table 2. The production of MAbs against purified FG, F12, and F13 (Pap) fimbriae will be diescribed slsewhere (J. M. de Ree and J. F. wh def Bosch, stubmited for publication). F 8 fimbriae were purified from the clloned straun AM1727 (pANN921), F12 fimbriae were purified from the wild-type strain C1979, and F13 fimbriae were purified 
TABLE 1. Bacterial strains used in this stwdy

\begin{tabular}{|c|c|c|c|}
\hline Daterefial strein & serotype & 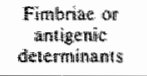 & Nefierence \\
\hline \multicolumn{4}{|l|}{ Whold tyoe } \\
\hline C1212 $(1010)$ & $06: K 2: H 1$ & $\begin{array}{l}\mathrm{Fr}_{1}, \mathrm{FT}_{2} \text {, and } \\
\mathbb{1} \mathrm{C}\end{array}$ & 12 \\
\hline C1254 & $\mathrm{O} ; 5: \mathrm{K}^{-}: \mathrm{H} 5$ & $\mathrm{Fe}$ & 12 \\
\hline C1018 & $\mathrm{O}_{2}: \mathrm{K}: 5: \mathrm{H} 4$ & $\mathrm{Fg}$ & 12 \\
\hline C1976 & OI:KI:HJ & Fil & 12 \\
\hline C1979 & O16:KI:H & $\mathrm{F} 12$ & 12 \\
\hline $\mathrm{Cl3} 4$ & $\mathrm{O} 4: \mathrm{K} 12: \mathrm{HS}$ & $\begin{array}{l}\mathrm{Fy}, \mathrm{Fi}, \mathrm{F} 13 \\
\text { and } 1 \mathrm{C}\end{array}$ & 12 \\
\hline $\mathrm{SPIY3}_{3}$ & $0114: ?$ & a and $\mathrm{e}$ & 13 \\
\hline $\mathrm{SP} 7$ & $018 \mathrm{KS}$ & $c_{1} d$, and $f$ & 13 \\
\hline SPS7 & O157:K- & $a$ ma & 13 \\
\hline$S P 201$ & Wontypable & $\mathrm{g}$ and $\mathrm{e}$ & 13 \\
\hline SP144 & $\mathrm{Or}: \mathrm{K} 13$ & and $g$ & 13 \\
\hline SP:58 & $0157 \mathbf{K}^{-}$ & and $b$ & 13 \\
\hline SPIOL & $01: K I$ & b. G. and e & 13 \\
\hline 196 & $04: K 6: 145$ & $E \backslash 3\left(P_{a p}\right)$ & 5 \\
\hline \multicolumn{4}{|l|}{ Cloned } \\
\hline AM1727(pPIL 110-70) & & 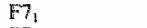 & 19 \\
\hline AM11727(pPIL $110-37)$ & & $1+7:$ & 20 \\
\hline$A M 1727(p A N N 921)$ & & 188 & $\begin{array}{l}\text { Hacker in } \\
\text { preparation }\end{array}$ \\
\hline AM1727(pPIL288-10) & & $\mathrm{Fg}$ & 2 \\
\hline AM1727(pPIL29)-15) & & $\mathbf{F} \# \mathbf{1}$ & 3 \\
\hline AM1727(pRHU845) & & F13 (Pap) & 6 \\
\hline AM1727(pDC1) & & Close & 1 \\
\hline
\end{tabular}

from the cloned strain AM1727 (pRHU845). The inmunoglobulin subclasses of the MAbs were determined with an EILISA as described previously (4).

Plate agglutination test. Bacterial agglutination assays were performed essentially as described for $O$-antigent typing by Guinee et al. (5). Bacteria were grown for $16 \mathrm{~h}$ and suspended in phosphate-buffered saline (PBS) with $0.25 \%$ Formalin to an optical density at $660 \mathrm{~nm}$ of 0.7. Bacteria were stained by adding a $0.05 \%$ gentian violet solution in PBS with $0.25 \%$ Formalin. Serial dilutions of the MAbs were made un $100 \mu \mathrm{\mu l}$ of PBS with $0.25 \%$ Formalin in microtiter plates (Thovadec). To each well, $1000 \mathrm{pl}$ of stained bacteria was added. Agglutination was read after overnight incubation at $4{ }^{\circ} \mathrm{C}$.

Coagglutination. S. auress Cowan 1 NCTC 8530 was kindly provided by Loek van Alphen. These bacteria werie grown for 16 h on Columbia agar plates. After three wasthings with PBS, the bacteria were suspended in PBS with $0.5 \%$ formalin and inceubated for $3 \mathrm{~h}$ at room temperature. Subsequently, the bacteria were washed four times with PBS, incubated for 10 min at $80^{\circ} \mathrm{C}$, and washed two times with PBS. Finally, a $10 \%$ (vol/wol) suspension was made in PBS with $0.01 \%$ sodium azide. This suspension was stored at $4^{\circ} \mathrm{C}$.

Immunogiobulin $\mathrm{G}$ (IgG) MAbs were coated to protein $A$ of the $S$. aureus suspension as described by Kromwall (9). Briefly, $50 \mathrm{pl}$ of undiluted MAb was incubated with $0.5 \mathrm{ml}$ of the $S$. ourews suspension for 10 min at room temperature. Agglutination assays were performed on glass sllides by mixing 1 drop of a bacterial suspension in PBS and $1 \mathrm{drop}$ of an MAb-coated $S$. anrews suspension. Agglutination was scored within $1 \mathrm{~min}$.

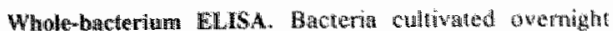
were sispended in 50 ma bicarbonate conting butfer $1 \mathrm{pH}$ 9.6) tho an optica density of 1.0 st 600 nin and diluted eight times in coating butfer. Microticer plates factivated poly vinyl chlloride: Flow Laboratorites, Inc, were coated with lon $\mu$ l of the diluted backenal suspersion per well and dried overnight at $37^{\circ} \mathrm{C}$. On the next day, the microtiten plates were washed four times with PBS conthining $0.03 \%$ Twean 20 (PBST). After 1 h of incubaton at roont temperature willi $15 \%$ newbon calf semum (OLBCO Laboratories) in PBST (NBST), the microtint plates were washed four times wish PBST and them incubated with 100 wal of 1:100-diluted MAb in NBST for 2 h at room temperature. Subsequently, the wells were washed four times with PBST and noubated for 3h at room temperature with 190 ful of goat antimouse $1 \mathrm{gO}$ theavy and light chins conjugited to peroxidase (Nordic Laboratories): the conjugate was diluted $1: 1,000$ in NBST. Antifimbria antibody activity was detected colorimetricaly by adding $0.05 \%$ o-phenylenediamine in citrate-phosphate betfer $(\mathrm{pH} 4.5)$ containing $0.005 \% \mathrm{H}_{2} \mathrm{O}_{2}$. The reaction was developed in the dark for 15 min at room temperature and terminated with $2 \mathrm{M} \mathrm{H}_{3} \mathrm{SO}_{4}$. The $A_{49}$ was metsured in a Titertek Multiskan (Flow Labotatories. Ins.). Wells filled with $\mathrm{H}_{2} \mathrm{O}$ were used as blanks.

\section{RESULTS}

The reaction of the MAbs raised aganst the $P$ fimbriae $\mathrm{F}_{1}, \mathrm{Fr}_{2}, \mathrm{Fg}$, and $\mathrm{Fll}$ was tested in the plate anglutination assay with strains expressing homologous funbriac. All MAbs reacted with the fimbriae on the homologons $E$, coli AM1727 strains expressing cloned finbriae (Table 3). Strain AM1727 (pPIL288-10) showed atotongghtination with this method. Only MAb M6-8 reacted with the fimbriae on the wild-Iype strain C.1212. None of the other MAbs recognized the fimbriate on the homologous wild-type streins with this plate agglutination assery.

The MAbs were also tested in a slide agglutimation lest (dala not shown), and none of them reacted with the homologous wild-type strains. Subsequently, we tried to improve this agglutination by coating the NAbs to protein $A$ of an $S$. aureus suspension as described above. With this coagglutination test only the $\mathrm{IgG}$ MAbs raised against the $\mathrm{F} 7_{1}, \mathrm{Fl}_{2}$, and F11 fimbriae were tested. In this assay all the MAbs recognized the fimbrige on the hamologous cloned strains (Table 4). MAb M7-6 also reacted with the fimbriae on the heterologous cloned sinain, AM1727 (pDCl). MAbs M6-3 and $\mathrm{M} 2-1$ also agglutinated the wild - Iype strain C 1212, which expresses homologous fimbriae. MAb M7-6 did not aggluinate the homologous wild-type strain C1976. However. this

TABLE 2. MAbs used in lhis study

\begin{tabular}{|c|c|c|c|}
\hline $\mathrm{MAb}$ & $\begin{array}{l}\text { \#nominoglatbulin } \\
\text { subcolusis }\end{array}$ & 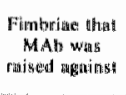 & $\begin{array}{l}\text { Dinbritis } \\
\text { recognized by } \\
\text { MAY In in thmbita } \\
\text { ELISA }\end{array}$ \\
\hline $\mathrm{M} 6-3$ & $\lg C_{2}$ & $\mathrm{Fl}_{\mathrm{H}}$ & $\llbracket 77^{\circ}$ \\
\hline $\mathrm{M} 6.8$ & $\lg \mathrm{M}$ & $\mathrm{m}_{\mathrm{H}}$ & $P 7_{1}^{\prime \prime}$ \\
\hline$M 2-1$ & $\lg 62 b$ & $17 \gamma$ & $\mathrm{Fr}_{2}^{n}$ and Fingan \\
\hline$M 17+9$ & $\lg M$ & 178 & 10 \\
\hline$M 4-7$ & $1 \mathrm{~g} M$ & 10 & $\mathrm{FO}$ \\
\hline$M 7 \cdot G$ & $\lg 01$ & {$[1]$} & W11 and Cleseg \\
\hline M14-5 & $\lg M$ & 1012 & $\mathrm{I}^{1+1} \mathrm{Z}^{\mathrm{b}}$ \\
\hline M8-16 & $\lg M$ & F13 (Pap) & Fo3 $\left(P_{\text {atp }}\right)^{t}$ \\
\hline
\end{tabular}

- See refenence 4 .

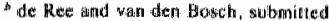


TA

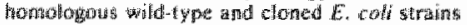

\begin{tabular}{|c|c|c|c|c|c|}
\hline \multirow[b]{2}{*}{ 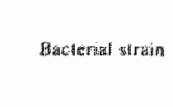 } & \multirow[b]{2}{*}{ Finderatace } & \multicolumn{4}{|c|}{ Tibet at } \\
\hline & & $\begin{array}{l}F \\
M \\
M B D\end{array}$ & $\begin{array}{c}W_{4} \\
M A^{2} \\
H_{2}\end{array}$ & $\begin{array}{c}\text { my } \\
\text { Ms }\end{array}$ & 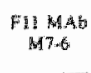 \\
\hline $\mathbb{4} 1212$ & 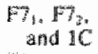 & 40 & 0 & & \\
\hline Cloldi & $\mathrm{frg}$ & & & 0 & \\
\hline $\mathrm{C} 1976$ & $F H$ & & & & 0 \\
\hline
\end{tabular}

AM127(SPL1L 1070$)$ FT.

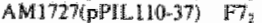

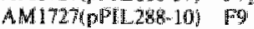

AM1727PPIL 2914.15) F11

9.120

10,240

$A^{b}$

$>40,0,00$

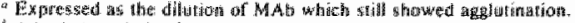

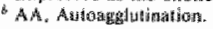

MAb did react with the fimbriat on the wild wype strains SPI33 aund SPI01

All the Mabs described in Tuble 2 were tested in an ELISA with whole bacteritas an antigen. In this ELISA all the MAbs roacted with the hmbriae on the Homologous cloned strains (Tablle S). The F11 MAb M7-6 also reacted with the fimbriac on the hererologots clloned strain AM1727 (pDCI). All the MAbs reacted with the fimbriae on the homologous wild-type stridins, except for the Fll MAb M76, which did not reach with the Fll fimbriae on the wild-uype strain C1976. However, this W11. MAb did react will the fimbriate on the will-type strains SP133 and SP101. $\mathrm{MAb}$ M14-5, raised against purified $\mathrm{F} 12$ fimbriat from the wild-lype strain C1979, also reacted with the fimbriae on the wild-type strain C1979. In contrast, the F12 fimbriae on strain C134 were noll recognized by MAb M14-5.

MAb M17-9, raised agaimst purified Fo fimbriac from the cloned strain AM1727 (pANN921), reacted with the fimbriae on the wild-fype strains C1254 and SP7.

\section{DISCUSSION}

In this paper wa tested three different methods for the determination of serologically different $P$ fimbriae on clinical

TABLE 4. Congglutination of MAbs with wild-type and cloned strains

\begin{tabular}{|c|c|c|c|}
\hline \multirow{2}{*}{ Bucteriat strain } & \multicolumn{3}{|c|}{ Corggliutination of : } \\
\hline & $F, M A B M G-3$ & F. MAto M2-1 & Fl1 MAb M7-6 \\
\hline C 1212 & is & ++ & - \\
\hline C1254 & $\ldots$ & -. & - \\
\hline Clols & - & - & -. \\
\hline C1976 & - & - & - \\
\hline c1979 & - & - & - \\
\hline SPI33 & - & - & +4 \\
\hline SPlOV & $m$ & - & +4 \\
\hline AS1127(pP1L110-70) & + & - & .n. \\
\hline AN11227(pPIL110-37) & $=$ & +4 & $=$ \\
\hline AN1727(pANN921) & - & $\ldots$ & - \\
\hline AM1727(pPIL288-10) & - & $\infty$ & - \\
\hline AM1172)(pPIL.291.15) & - & - & $+x++$ \\
\hline AM172\%(pRHU845) & - & ve & - \\
\hline$A M 1727(\mathrm{pDC} 1)$ & - & - & ++1 \\
\hline
\end{tabular}

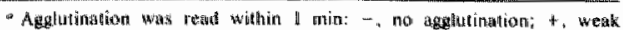

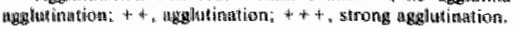

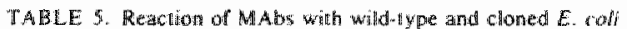

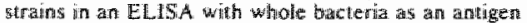

\begin{tabular}{|c|c|c|c|c|c|c|}
\hline \multirow[b]{2}{*}{ Dacherial antarm } & \multicolumn{6}{|c|}{ Reerticitions of: } \\
\hline & 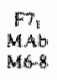 & $\begin{array}{c}F P_{5} \\
M A B \\
M 2\end{array}$ & $\begin{array}{c}F 8 \\
M A b \\
M P-4\end{array}$ & 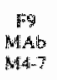 & $\begin{array}{l}F H \\
M A b \\
M 76\end{array}$ & $\begin{array}{c}F{ }_{2} \\
M A b \\
M 14-5\end{array}$ \\
\hline
\end{tabular}

\begin{tabular}{lllll}
\hline C1212 & 8 & 8 & & \\
C125id & 8 & 8 & 8 & \\
C1018 & & & & if
\end{tabular}

\section{C1976:}

C. 1979

C. 13.4

SPT

SP:3

SPOO

396

AM 1727(pPIL.110-70)

AM17270PUL 110-3J

A M1\%27(pAND921)

AM1727(pPUL28\% 10)

AM]727(pPIL 201-15)

AM1727(pRHU845)

AM1?27(pDCL!)
9

3

8

9

9

9

a Expressed as $A$ do umits: 1 unit equals an $A$ swo of 0.29 .

isolates of $E$. coli. The classification of these $P$ fimbriat was recently described by $\emptyset$ rskow and $\emptyset$ rskow (12). "They used polyclonal antisera raised against whole cell cultures which had been made more fimbria specific by absotption with the homologous nomfimbriated strain grown at $20^{\circ} \mathrm{C}$. The disadvantage of polyclonal antisera against $P$ fimbriae is that these amtisera are not specific for each type of $\mathrm{P}$ fimbria, as was shown by Korhonen et al. (8) and de Ree et al (4) in ELISA studies. Newertheless, Drskov and Orskow (12) were able to use these polyclonal antisera in crossed irmumelectrophoresis and crossed-line immunoelectrophoresis as very sensitive methods to discriminate between serologically different fimbriate. With these methods they were able to demonstrate seven serologically different fimbriae (F7 to Fd2) on clinical isolates. However, crossed-immunoelectrophoresis technique for F-antigen determination is cumbersome and can only be carried out in highly specialized laboratories. The main purpose of this study was to devellop a simple and fast method that uses the recently produced specific MAbs to determine the serologically different $P$ fimbriae on clinical isolates of $E$ coli.

The first mathod to be tested was a plate agglutination assay. All the MAbs agglutinated the homologous cloned strains, except for AM1727 (pPIL288-10) (Table 3). This strain showed atotosgglutination, which was probably caused by the extremely high fimbria expression of this cloned strain (2). Only MAb M68 weakly agglutinated the homologous wild-type strain, whereas the other MAbs did not show any reaction with the wild-type strains. This result can be explatined by the lower number of dimbriae present on wild-type strains than on cloned strains, a fact which was recently demonstrated for the Find and fll wildype and cloned strains by electron microscopy $\{2,3)$. Furthermore, in a slide agglutination test the MAbs did not agglutinate the wild-type strains. From these results, we concluded that direet agghtination is not sensitive enough for screening the 
p frmbriae on willd-type strans. Therefore, we tried to amplify agglatination by coating the $M A$ bs to protein $A$ of at S. aureas suspension. A disadwantage of this method is that only IgG MAbs could be used. Because all the F9 MAbs were of the $\mathrm{dg} M$ subclass (4), these MAbs could not be used in this method. The other MAbs tested in this assay agglt tinated the homologous cloned strinins, and the $\mathbb{E} 11 \mathrm{MAB}$ even agglutinated strain AM1727 (pDCl) (Table 4). In contrast to the resulis of the plate agglutination assay. almost all the MAbs agglutinated homologous wild-type strains in the coagghtutination assay. The only exception was the FH1 MAb M7-6, which did not agglutinate the homologous wild-type strain C1976, probalily because of the very low number of F11 fimbriae on this wild-type strain (3). However, the F11 MAt did agglutinate some other wild-type strains. From these results, we concluded that the coagglutination test is more sensitive than the plate agglutination test but still has the disadvantage that only IgG MAbs can be used. Another drawback of this method is the difficulty of reading the results un an objective way.

The last method to be tested was a whole-bacterium ELISA. During the course of this study, more MAbs were available than in the former two assays. Since these two assays were found to be unsatisfactory for our purposes, we did not lest the more recently obtained MAbs in the agglutination assays, but we did test the whole series of available MAbs in the ELISA. All the MAbs tested in this method reacted strongly with the fumbriae on the homologous cloned strains (Table 5). The F11 MAb M7-6 recognized the Clege fimbriae on strain AM1727 (pDCl), as was also shown with the coagglutination assay (Table 4). From these results, we concluded that Clegg fimbriae are probably identical to Fll fimbriae. All the MAbs also recognized the fimbriae on the homologous wild-type strains with this method, except, again, for the FL1 MAb M7-6. However, the F11 MAb M7-6 did detect the fimbriae on the wild-lype strains SP133 and SP101. So, this MAb could still be useful for the determination of F11 fimbriae on wild-type strains. The reaction of the F11 MAb M7-6 in the coagglutination assay and the wholebacterium ELISA with strains SPL133 and SPIO] slrongly suggested that these strains express Fl 1 fimbriae. Similarly. as in the coagglutination test, the negative reaction of the F11 Mab M7-6 with the fimbriae on the homologous wildtype strain C1976 was probably caused by the very low number of F11 fimbriae on this strain (3).

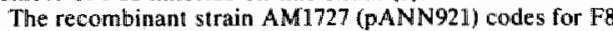
fimbriac, which were cloned by J. Hacker (manuseript in preparation) from the wild-type strain 2980 (serotype O18: $\mathrm{KS:H}^{-}$) described by Jann el al (7). MAb M17.9, which was raised against the purified $\mathrm{FB}$ fimbriae from the recom. binant strain, reacted as expected with the wild-type Fis reference strain C125it and also with strain SPT. So, the Hatter strain also expresses $F 8$ fimbriate.

The F12 MAb M14-5 recognized the F12 fimbriae on the homologous wild-iype strain C 1979 but not the F12 fimbriae on the wild atype strain C134. This result could mean that the F1.2 fimbriae on strain C134 are expressed in very low numbers or that these F12 fimbriae are different from the F12 fimbriae on strain C1979. This last explanation would mean that there are two kinds of F12 fimbria. This possibility has alieady been suggested by the crossed-immunoelectrophoresis results for strain C1979 of Orskow and Drskov (12). Further studies are required before F12 fimbriac can be distinguished into $\mathrm{F}_{12}$, and $\mathrm{F} 12$, fimbriae.

From the results of the wholembacterium ELISA we concluded that this method is the best one for the detection of $P$ ? fimbriae on wild-type E. col strains. This, whole-bacteritam ELISA us not more seotitive that the coagglutingtion method but has two major advantages" (i) all the immuno. globulins can be used in the ELISA, whereas in the cong. gutination test only lgo MAbs can be used; (ii) the results of the ELISA can be read in an objective whe in contrast to the results of the coagglutination test.

In a fimbrie ELISA we have demonsirated that MA M2-1 reacted with $\mathrm{FT}_{2}$ and $\mathrm{F} 9$ fimbriac (4: see Table 2). However. the reaction with the fo fimbriae could nether be shown in the coagghutingtion test nor in the whole-bacterium ELISA. This result was probatoly caused by the weak reaction of MAb M2-1 with the F9 fimbriae.

Only the finbriae of three SP strains (SP7. SPI33, and SP101 could be determingd with the MAbs. All SP strains were, just like the reference strains for fimbriae FT to 13. isolated fron urinary tract infections, and all expressed p fimbriae (14). However, the serotype of some SP strains (e.g., SPS7 and SP88, OL157:K-) is not common arnong uropathogenic strains (17), and so it is possible that these strains also express rare fimbrime. Preliminary data on at limited number of our collection of uropathogenic $\mathbb{E}$. cols strains showed that we could determine the P frmbriat on $80 \%$ of the strains with the MAbs used atr this study. So, fimbriae $F 7$ to F13 are probably the most corrimon fimbriae among uropathogenic E. coli

With the whole-bacterium ELISA and the MAbs against the various $P$ fimbriae we have developed an easy and fast method for the determination of $\mathbb{P}$ fimbriae among uropathogenic $E$. colli, With this method we have planned to do epidemiological studies on the distribution of $\mathbf{P}$ fimbriat among wild serolype with the for serolype.

\section{ACKNOWLEDGMENT}

This work was supported by the Duich Kidney Foundation (grant (21320).

\section{LITERATURE CITED}

1. Glegg, \$. 1982, Cloning of genes determining the production of mannose-resistant fimbribe in aropathogeric strain of Esche. richich coli betorging to serogrowp 06 , Infect. Inmum. 38: 739.744

2. de Ree, J. Ma, P. Schwillens, L. Prones, 1. Van Die, $H_{\text {. }}$ Bergmans, and J, F, van den Bosch. 1985. Moleculiat cloning and characterization of Fo fimbrime from a uropathogenic Escherichin cofi. FEMS Microbioll. Left. 24:163-1,69.

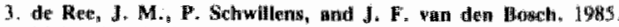

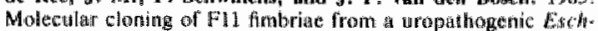

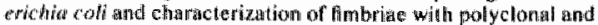

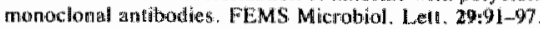

4. de Ree, J M., P. Scthwlllens, and J. F, wan den bocth, 1985.

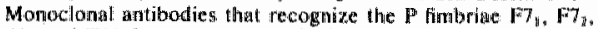

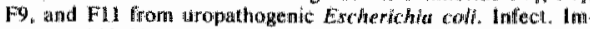
mun. 50.900-904.

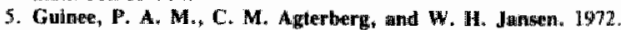
Escherichis coll $\mathrm{O}$ antigen 4 ping by means of a mechanized microtechnique. Appl. Microbiol. 24:127\%131.

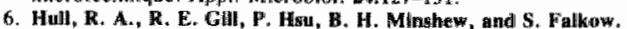
1981. Construction and expression of recombinart plasmids encoding aype 1 or Dumannose-resistant pili flirom at wringry tract infection Escherichion colli isolste. Infect. Immun. 33433-938

7. dann, K., B. Jann, and C., Schmidt. 1881. SDS polyacrylarnide gel electrophoresis and serological analys of pill from Esche-

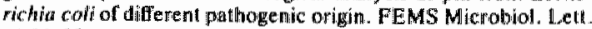
1.1:21-25.

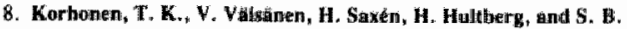




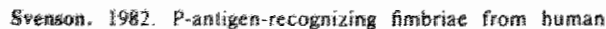

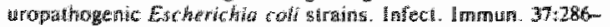
291.

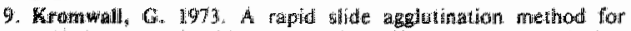
typing pne umowocei by mean of specific antibody adsorbed yo proten A containing staplyylowosci. I. Med. Microbiol. 6:187194.

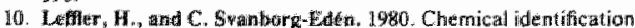
of a glyeosphingolipid recepror for Escherichia coll atashing to

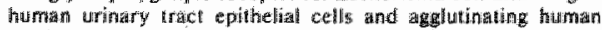
erythrocytes. FEMS Microbiol Lett 8:127-134.

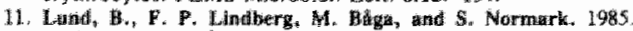

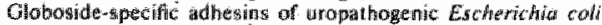
are encoded by simitar irais wcomplemerutable gene chosters, In Bacteriol. $162: 129 \mathrm{y}-1301$.

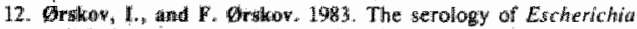

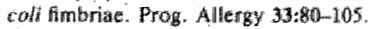

13. Parry, S. H., S. N. Mersham, and M. Sursman. 1982. The biological and serological properties of adhesion determinants of Ezchericfur coll isolated from urinary inat infections. p.

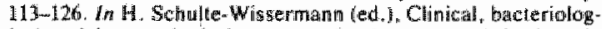
icall and immunological aspecis of urinary tract infections in children. Georg Thieme Veriag, Stutgart. Federal Reputbic of Germany.

14. Parry : S. H., and D. M. Blooke. 1985. Adhesing and collonization factors of Efcherichio costi, p. 79-154. In M. Sussman (ed ), Virulence of Escherichia colli. Academic Pressi Inc. (London), Lid. . Londion.

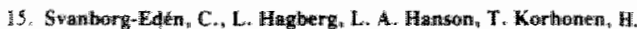

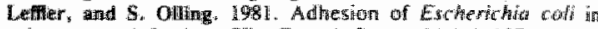
unimary tract inferwion. Ciba Found. Symp. 80:161-187.

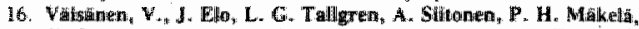
C. Svanborg-Eden, G. Kalleniso, S. B. Svenson, H. Hubtherg,

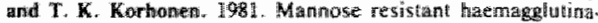
lion and Puatiger recogmition are characteristic of Escherichio colis causing primany pyelomephritis. Lancer ta: $1366-1369$

17. van def Bosch, J. F. P. Postrax, P. A. R. Koopman, J. De Grasif, D. M. MacLaren, D. G. Van Brenk, and P. A. M.

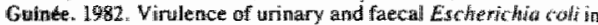
relation to serotype, hatmolysisy and hatmagglutination. J. Hyg. 45: 567-577.

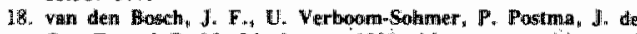

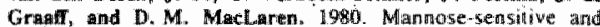

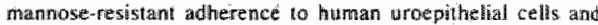
urinary wirulence of Escherichia cohi. Intect. Imaruan. 29: 226-23y.

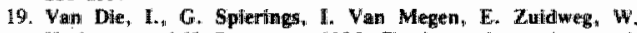
Hoekstre, and H. Bergmans. 1985. Cloning and genetic organization of the gene cluster encoding $F T_{1}$ fimbriat of a uropathogenic Escherichia coli and comparison with the $177_{3}$ gene cluster. FEMS Microbiol. Let: 28:329-334.

20. Van Die, I. I. Van Megen, W. Hoekstra, and H. Bergmans. 1984. Molecular organisation of the genes involved in the production of $F 7_{2}$ fimbriae, carsing mannose resistant haemagglutination of a uropathogentic Escherichion cofi $06 \mathrm{~K} 2 \mathrm{H1}: \mathrm{F} 7$ sirain. Mol. Gen. Genet. 194:528-533. 


\section{ETMBRTAE SEROTYPES OP ESCHERICHIA COLI STRAINS ISOLATED}

FROM EXTRA INTESTINAL INEECTIONS

\section{INTRODUCTION}

Escherichia coli is a pathogen in urinary tract infection and mentugitis. A variety of factors e.g. $0: K$ antigens, adhesion properties and hemolysin production may influence the virulence of pathogenic E. coll $(1,2)$. Ihe $0: \mathrm{K}: \mathrm{H}$ seratypes of these $\mathrm{E}$. coli strains belong 1 in most cases to restricted well defined groups of serotypes $(3,4)$. Thus, each $0: k: H$ serotype has a characteristic pathogenic capacity.

The presence of $P$ fimbriae on uropathogenic $E$. coli has been assocfated with virulence (5). With the ald of these fimbrlae E. coll can colonize the urinary tract. These fimbriae on $\mathrm{E}$. coll appear to be related to the strains ability to agglutinate erythrocytes and to attach to eplthelial cells. Two types of hemagglutination can be distinguished. 1. a mannose sensitive hemagglutination (MSHA) correlated with type 1 fimbriae and $f 1$. a mannose resistant hemagglutination (MRHA). Fimbriae which cause a MHA can be divided In $P$ (6), $M$ (7) and $S$ (8) fimbriae, based on the receptor specificfty. Among uropathogenic $\mathrm{E}$. coli it is generally accepted that especially the MR fimbriae which belong to the $\mathrm{P}$ class play an important role in the pathogenesis. of pyelonephritis (5).

The $P$ fimbriae differ in serotype (9) and the mol. Weight of the fimbriae subunit (10). Until now, efght differente $\mathbb{P}$ fimbriae have been described. These F fimbriae were characterized with polyclonal antisera 1 n a crossedImmuno-electrophoresis system and were numbered F7 - F13 (4, 9). There are only a few studies which have investigated the presence of a speciflc $P$ fimbriae serotype in correlation wh the $0: K$ serotype $(9,11,12)$. In this study we have determined the $P$ fimbriae serotype of $\mathbb{E}$. coll, isolated from urinary tract infections and meningltis, with specific anti-fimbriae mono- 
clonal atibodles (MAbs). These MAbs were recently developed against purified $P$ flubriae $(13,14)$. The correlation between $0: K$ serotype and the fimbriae seratype 11 be discussed.

\section{MATERLALS AND METHODS}

\section{Bactertal atrains}

The atrains used in this study firstly were MRHA stralins of previously described collections (AD...., Z0....) E.coli $(15,16,17$ ). Secondly, strains were isolated from patients wh urosepsis (NS....). This collection of 49 ctrains was obtalned from bacterlologlcal laboratorles in The Netherlands, 1solated from 1983-1985. The average age of the patients was $67 \pm 16$ years, whereas $65 \%$ of the patients were females *

28 strains 1 solated from children with meningitis (MA....) were kindly provided by Dr. L. van Alphen (Medical Microblology, University of Amsterdam, The Netherlands), and described before (18).

A11 these strains were examined for the presence of MR fimbriae and the production of hemolysin. Strains which showed a MRHA were further investigated on $0: K$ serotype, the expression of $\mathrm{P}$ flmbrlae and the serotype of the $\mathrm{P}$ $\mathbb{1} 1 \mathrm{mbr}$ lae.

\section{Hemagglutination act1vity}

The MRHA with human erythracytes was determined as described (2). For the MRHA assay bacteria were grown on bload agar plates (Oxold Ltd.) Cells were suspended in saline and serial dilutions of bacterlal cells were added to the erythrocyte suspension. For testing mannose sensitivity the erythrocyte sugpension contalned $1 \%$ D-mannose. Agglutination was read after incubation for 2 h on ice.

\section{The $\mathrm{P}$ receptor test}

Fimbriae of the clinical lsolates were tested for their ability to recognitze the globoside structure $\alpha-D-G a l \underline{p}-(1-4)-\beta-D-G a 1 \underline{p}$. Bacteria grown on blood agar plates were mixed on a glass slide with latex beads which were coated with the globoside structure (19). Latex beads devold of the globoside structure were used as a control. If $P$ fimbriae were present on the wild type strains macroscoplc agglutination was apparent within 1 winute. 
Hemolysis was tested on washed blood agar plates as described by Van den Bosch (20). Sheep blood was washed three times with saline and added to blow agar base nr. 2 (Oxold Ltd.) to a final concentration of $5 \%$. Hewolysils was scored after overnight incubation.

\section{O:K serotype}

Serotyping of 0 and $K$ antigens was performed as described (15) by W.H. Jansen and P.A.M. Guince (National Institute of Public Health, Blithoven, The Ne therlands).

Monoclonal antibodies agalnst $P$ fimbrlae

The production of MAbs against the $P$ fimbriae $F 7_{1}, F 7_{2}, F 8, F 9, F 11, F 12$ and $\mathbb{F} 13$ was recently described $(13,14)$. Al1 fimbrlae were purlfled from strains which expressed cloned fimbriae except the F12 fimbriae which were puriffed from the wild type reference strain C1979. In Table 1 the MAbs used In this study are listed, selected on specificity. The MAbs $20025-F 1$ and 20025-F2a were raised against the Fy and F12 fimbriae, respectively, from the strain 20025 (C. Abe et al., submitted for publication). These latter two MAbs were klndly provided by $k$. Jann (Max-Planck-Instltut fur Immunblologle, Freiburg, West Germany). Recently, we have shown that the MAbs M14-5 and 20025-F2a recognize different epitopes on F12 fimbriae and we suggested that there are probably two serotypes of $\mathrm{F} 12$ flmbrlae (J.M. de Ree et al., submitted for publication). The F12 fimbriae which are recognized by the MAb 20025-F2a are referred as F12 related fimbriae. 
TABLiE 1: Monoclona 1 antibodies used in this study

MaB Fimbriae serotype Parental strain Serotype

\begin{tabular}{|c|c|c|c|}
\hline $46-8$ & $\mathbb{N}_{\mathbb{1}}$ & $A D 110=1212$ & $06: \mathrm{K2}: \mathrm{H} 1$ \\
\hline$M 2-1$ & $7_{2}$ & $A D 110=C 1212$ & $06: \mathrm{K} 2: \mathrm{HI}$ \\
\hline$M 17-9$ & 8 & 2980 & $018: \mathrm{K} 5: \mathrm{H}-$ \\
\hline$M 4-7$ & $\mathbb{F} 9$ & C1018 & $02: \times 5: 144$ \\
\hline$M 7-6$ & F 11 & C1976 & $01: \mathrm{K1}: \mathrm{H} 7$ \\
\hline$M 14-5$ & $F 12$ & C1979 & $016: \mathrm{K} 1: \mathrm{H}-$ \\
\hline $20025-E 2 a$ & F'12 related & 20025 & $04: \mathrm{K} 12: \mathrm{H}-$ \\
\hline$M 8-16$ & F 13 & $J 96$ & $04: \mathbb{K} 6: \mathrm{H} 5$ \\
\hline $20025-\mathrm{F} 1$ & $\mathrm{Fy}$ & 20025 & $04: \mathrm{K} 12: \mathrm{H}-$ \\
\hline
\end{tabular}

a Alz monoctonal antibodies were raised against purified fimbriae isolated from trains harboring plasmids encoding for $P$ fimbriae $(13$, 14). Only the F12, F12 related, and Fy fimbriae were purified from wild type straine.

Whole bacteria ELISA for screening of $P$ fimbrlae on wild type E. coll strains A whole bacteria ELISA was carried out as described previously (14). Brlefly, bacterla were suspended in blcarbonate coating buffer and coated on microtiterplates. These microtiterplates were washed several times with saline and preincubated with New Born Calf. Serum, followed by an incubation wth the 1: 100 diluted MAbs. Ant1-fimbriae activity was detected colorimetrlcally after incubation with goat anti-mouse antiserun, confugated with peroxldase and addition of the substrate o-phenylenediamine. Absorbance at 495 no was deterained with a Titertek multiscan ELISA plate reader. Negative controls re treated in the same way except that the bacterial strains were incubated with saline, instead of MAbs *

Bacterial strains were supposed to express a certain kind of $p$ flmbrlae when the value of the absorbance was three times higher than the negative control value. 
MRHA and $P$ agglutination

AlI strains which exhibited MRHA are listed in Table 2, according to their o serotype. The percentage of MRHA expressing strains in the urosepsis (NS) and meningitis (MA) collection was $39 \%$ and $32 \%$, respectively. All the MRHA strains listed in Table 2 expressed $p$ fimbriae except strain NS26.

0:K antigen

The 0 groups 1, 2, 4, 6, 7, 18, 25 and 75 comprtsed $82 \%$ of the 33 MaHA positive UTI strains. A minority of these MRHA positive UTI stralns belonged to the 0 serotype 014, 021, 057, 077, 083 and 0128.

Three out of mine MRHA positive meningltis strains belonged to the 07 serotype and two strains of this group expressed the 01 serotype.

Among the MRHA positive UTI strains and the MRHA positive meningitis strains $26 \%$ and $77 \%$, respectively, expressed the $K 1$ serotype.

Production of hemolysin

Hemolysin was expressed by $52 \%$ of the MRHA positive UTI strains, wheras anly 1 out of 9 (11\%) MRHA positive meningitis strains expressed hemolysin. Remarkably a11 04,06 and 018 strains in Table 2 expressed hemolysin.

Serotype of fimbriae

With the ald of the Mabs we could determine the fimbriae of 24 out of 33 (73\%) of the MRHA positive UTI strains, and on 6 out of $9(67 \%)$ of the MRHA positive meningtis stralns.

As shown in Table 2 many strains expressed multiple flmbrlat serotypea. The most common $\mathrm{F}$ types of the MRHA positive UTI strains were the Fll, F7, and F8 fimbrlae, which were expressed by $9(27 \%), 7(21 \%)$ and $6(18 \%)$ stralns, respectively. The other $p$ flmbrlae serotypes were almost equally distributed among the MRHA posttive UTI stralns: F7, fimbriae were found on 3 (9\%) strains; F9 fimbriae on 1 (3\%) strain; Fl2 fimbrlae on 3 (9\%) strains; F12 related fimbriae on 3 ( $9 \%$ ) strains; F13 fimbriae on 1 (3\%) strain and the Fy fimbriae on $4(12 \%)$ straims. Among the MRHA positive meningttis strains 3 (33\%) expressed F11 fimbriae; F8 fimbriae were expressed by 2 (22\%) strains and F9 fimbriae by $1(11 \%)$ strain, whereas the flmbrlae on three stralus 
TABLE 2: Characterdstics of E. coll strains from extraintestinal infections

\begin{tabular}{|c|c|c|c|c|c|c|}
\hline \multirow[t]{2}{*}{ Strain } & \multirow[t]{2}{*}{ Serotype } & \multicolumn{5}{|l|}{ Flmbrlae } \\
\hline & & type & MRHA & $\mathrm{P}$ & $\mathrm{HIy}$ & Source \\
\hline NS2 & $01: K L$ & F11 & + & + & - & UTI \\
\hline $\operatorname{MS} 24$ & $01: K 1$ & $F 7_{1}, \mathbb{1} \mathbb{1}$ & + & + & - & UTI \\
\hline NSSO & $01: \mathrm{KL}$ & E9 & + & + & - & UTI \\
\hline $\operatorname{AD} 312$ & $01: K 1$ & $\mathrm{E7}, \mathrm{FLI}$ & + & + & - & UTI \\
\hline MA4 & $01: K 1$ & $\mathrm{Pg}$ & + & + & - & Menin \\
\hline MA17 & $01: \mathbb{K L}$ & F11 & + & + & - & Menin \\
\hline NS 11 & $02: \mathbb{K} 1$ & F11 & + & + & - & UTI \\
\hline NS4 4 & $02: \mathbb{K} 7$ & $\mathrm{~F}_{1}$ & $*$ & + & - & UTI \\
\hline NS10 & $02: K+$ & E 11 & + & + & - & UTI \\
\hline NS 30 & $02: K+$ & F8 & + & + & - & UTI \\
\hline NS25 & $04: K 12$ & F11, F12 re1 & + & + & + & UTI \\
\hline $\mathrm{AD} 314$ & $04: \mathrm{K} 12$ & $F 11, F 12$ rel & + & + & + & UTT \\
\hline AD111 & $06: \mathrm{k} 2$ & $F 7_{1}, F 7_{2}, F y$ & + & + & + & UTT \\
\hline AD115 & $06: \mathbb{K} 2$ & $\mathrm{~F} 7_{1}, \mathrm{~F} 7_{2}, \mathrm{Fy}$ & + & + & + & UTL \\
\hline $\operatorname{NS} 22$ & $06: \mathbb{R}+$ & & + & + & + & UTI \\
\hline NS46 & $06: \mathrm{K} 13$ & F12 & + & + & + & UTI \\
\hline NS28 & $07: \mathrm{K} 1$ & & + & + & - & UTI \\
\hline NS4 7 & $07: \mathrm{K} 1$ & & + & + & - & UTI \\
\hline MA2 & $07: \mathrm{KI}$ & & + & + & - & Menin \\
\hline MA 6 & $07: \mathrm{K} \mathbb{1}$ & & + & + & - & Menin \\
\hline MA13 & $07: \mathrm{K} 1$ & & + & + & - & Mentn \\
\hline
\end{tabular}


TABLE 2: continued

\begin{tabular}{|c|c|c|c|c|c|c|}
\hline \multirow[t]{2}{*}{ Strain } & \multirow[t]{2}{*}{ Serotype } & \multicolumn{5}{|l|}{ Fimbrlae } \\
\hline & & type & MRHA & $\mathrm{P}$ & HIy & Source \\
\hline NS 3 & $014: K+$ & $\mathrm{F} 7_{1}, 13, \mathrm{Fy}$ & + & + & + & UTI \\
\hline NS 14 & $018: K 5$ & F8 & + & + & + & UrI \\
\hline NS23 & $018: k 5$ & F8 & + & + & + & UTI \\
\hline NS43 & $018: \mathrm{K}+$ & F8 & + & + & + & UTI \\
\hline AD119 & $018: K+$ & F 8 & + & + & + & UTI \\
\hline$A D 123$ & $018: \mathrm{K}-$ & $\mathrm{F} 12$ & + & + & + & UTI \\
\hline $\mathrm{AD} 325$ & $021: \mathbb{K}-$ & & + & + & - & UTI \\
\hline NS 48 & $025: \mathbb{K}+$ & & + & + & + & UTI \\
\hline$A D 303$ & $025: \mathbb{K}-$ & F11, F12 rel & + & + & + & UTI \\
\hline AD 313 & $025: K+$ & & + & + & - & UTI \\
\hline AD316 & $025: K+$ & & + & + & - & UTI \\
\hline MA8 & $025: K_{-}$ & F8 & + & + & + & Menin \\
\hline $\operatorname{AD} 317$ & $057: \mathrm{K}+$ & & + & + & - & UTI \\
\hline MAl & $057: \mathrm{K} 1$ & Fl1 & + & + & - & Menin \\
\hline NS7 & $075: K+$ & F8 & + & + & - & UTI \\
\hline$A D 340$ & $075: K+$ & & + & + & + & UTI \\
\hline $\mathrm{MA1} 2$ & $075: K+$ & $\mathrm{FB}$ & + & + & - & Menin \\
\hline AD309 & $077: K-$ & $F 7_{1}, F 11, F 12$ & + & + & + & UTI \\
\hline $\operatorname{MS} 26$ & $083: K 24$ & $\mathrm{~F} 7_{2}, \mathrm{Fy}$ & + & - & + & UTI \\
\hline$A D 308$ & $0128:(K 67)$ & & + & + & - & UTI \\
\hline MA18 & $0_{\text {auto }}: \mathrm{K} 1$ & F11 & + & + & - & Menin \\
\hline
\end{tabular}


could not be typed the Mabs.

Sxpression of certaln $F$ types was not restricted to certain $0: k$ serotypes. 7. Flmbrlae were found on $01: K L, 02: K 7,06: K 2,014: K+$, and $077: K-$ stralns: $7_{2}$ Flabriat were found on $06: k 2$ and $083: k 24$ strains; F8 fimbrlae were found on $02: K+, 018: K 5,018: K+, 025: K-$, and $075: K+$ strains; F9 flmbriae were found an 01:KL stralns; $\mathbb{P} 11$ flmbrlae were found on $01: K 1,02: K 1,02: K+, 04: K 12$, $025: K-, 057: K 1,077: K-$, and 0auto:K1 strains; 12 flabriae were found on $06: K 13,018: K-$, and $077: K-$ stralns; 12 related fimbrlae on $04: K 12$ and $025: K-$ stralus; Fl 3 fimbriae were found on a $014: K+$ strain, and the Fy fimbriae were found on $06: K 2,014: K+$, and $083: K 24$ strains.

It was striking that $01: K 1$ stralns expressed either F11 or $F 9$, or F7, and F11 flmbriae, that $F 8$ fimbriae were relatively frequently expressed by 018 and 075 strains, that both $04: K 12$ and both $06: K 2$ strains showed an identical fimbrlae phenotype, respectively, and that the fimbriae serotype of al1 $07: k 1$ strains could not be determined, Comparing urinary and meningitis strains with identical $0: k$ serotype no systematic difference was found in fimbriae phenotype e.g. NS50-MA4 (01:K1:F9); NS2-MA17 (O1:K1:F11); NS7-MA12 $(075: K 1: F 8)$; and the $07: K 1: F ?$ strains.

\section{DISCUSSION}

Virulence of E. coli in human extra intestinal infections has been assoclated with varlous properties e.g. $O$ and $K$ antigens, hemolytic activity, and the presence of fimbriae for adherence to epithelial cells. In the present study the P' fimbriae were serotyped from MRHA positive UTI and MRHA positive meningitis strains. Among the UTI strains the NS collection was made recently whereas the $A D$ and 20 collection were previously described $(15-17)$. of the $\mathbb{E}$. coli stralns of the NS collection, isolated from malniy elderly people with urosepsis, 39\% expressed MRHA. From these MRHA posttive strains a11, except one, expressed $\mathrm{P}$ fimbriae. The lncldence of $\mathrm{P}$ fimbriae on $\underline{E}$. coll has been studied intensively in strains implicated in acute pyelonephritis in chlldren $(5,21)$. It was demonstrated that there was a strong correlation between possession of $\mathrm{P}$ fimbriae $1 \mathrm{n}$ acute pyelonephrits $( \pm 90 \%)$ compared with acute cystit1s ( $\pm 19 \%)$, and asymptomatlc bacterfurla $( \pm 14 \%)$ in children. However, it is also important to consider host susceptibility when assessing the importance of adhesins. The effect of hast factors was clearly demonstrated in patients with recurrent pyelonephritis without reflux, where $74 \%$ of 
strains had adhesiwe capacity as indicated by MRLA, compared with only $38 \%$ in patients wh reflux (22). The low percentage (38\%) in the collection of NS strains which expressed MRHA, compared th the flubrlae expressing strains isolited from acute pyelonephrits in children can be explained by the host susceptiblifty of the elderly patients in the NS collection.

In the collection of meningitis strains (MA) $32 \%$ of the strains expressed $p$ fimbriae. This figure is in agreement with the results of korhonen et $a 1$. (23) who found that $38 \%$ of the E. coll strains isolated from meningltis expressed $\mathbb{P}$ fimbriae.

In the present study we serotyped the $\mathbb{P}$ fimbriae with Mabs. With the ald of the MAbs we could determine the fimbriae on 30 out of 42 (71\%) MRHA positive UTI and meningitis strains. Many strains expressed uultiple $p$ fimbriae serotypes. The FI1, F7, and F8 fimbriae were the most common P flmbriae among the MRHA positive UTI strains, whereas the other serotypes were equally distributed. Among the MRHA positive meningttis strains the $P$ fimbriae with serotype $\mathrm{F} 11, \mathrm{~F} 8$ and $\mathrm{F} 9$ were found.

In our study the expression of certain $F$ types was not correlated with certain $0: K$ serotypes. Other studles showed that there is a correlation between the $0: K$ serotype and the $F$ serotype. These studies demonstrated that $01: \mathrm{KI}$ was correlated wh F9 or Fll fimbriae (12); $02: \mathrm{KI}$ was correlated with F11 fimbriae (4); $04: \mathrm{K} 12$ was correlated w1th Fll and Fl2 related fimbriae (4); 06:K2 was correlated w1th F7 fimbriae (4) and the 018 serotype with F8 fimbriae (11). It has been suggested that these correlations result from a common clonal evolution of strains with certain antigenic characters $(3,24)$. A11 the strains with the above described correlation between $0: K$ serotype and F serotype were also found in our study, However, we found also stralns with these $0: K$ serotype which expressed other $F$ serotypes, e.g. 0l:KI with F7 and Fil fimbriae; 018 with F12 fimbriae; $025: K-$ with F8 fimbriae.

In our study not one of the $07: \mathrm{K} 1$ strains could be determined with the MAbs. The 07:K1 serotype was correlated with the F10 flmbriae (4), a flobrlae type which cannot be detected with our Mabs (Table 1). This could mean that the 07:K1 strains in our collection also express f10 flmbriae. 
1. Svanborg-bden C, Hagberg L, Hanson LA, Korhonen T, Leffler H, OLling S. Whe ion of E. coll in urinary tract Infection. In: Elliott $\mathrm{K}$, ed. Adhesion and microorganism pathogenicity. Ciba Foundation Sympasium 1981; 80 : 161-187: P1tman Medical, London.

2. van den Boach JF, Postma $P$, Koopman PAR, de Graaff J, MacLaren DM. W1 rulence of urluary and faecal Escherlchla coll in relation to serotype, haemolysis and haemagglutination. J Hyg 1982; 88: 567-577.

3. Valsanen-khen $V$, Elo $J$, Valsanen $E$, Siltonen $A$, brskov $I$, orskov $F$, Svenson SB, Make la PH, Korhonen TK. P Iimbriated clones among uropathogenfc Escherlchia coli strains. Infect Imm 1984; 43: 149-155.

4. orskov I, and orskov F. Escherichia col1 in extra intestinal infections. J Hyg, 1985; $95: 551-575$.

5. Valsanen $V$, EID J, Tallgren G, Siitonen A, Makela PH, Svanborg-Edén C, KHIlenius $G$, Svenson $S B$, Hultberg H, Korhonen TK. Mannose-resistant haemagglutination and $P$ antigen recognition are characteristic of Escherichia coll causing primary pyelonephritis. Lancet 1981 ; 11 : $1366-1369$.

6. Kallenius G, Svenson SB, Mollby $R$, Cedergren B, Hultberg $H$, Winberg $J$ * structure of carbohydrate part of receptor on human uroepithelial cells for pyelonephritogenic Escherichia col1. Lancet 1981; 11: 604-606.

7. Valsanen V, Korhonen TK, Jokinen M, Gahmberg CG, Ehnholn C. Blood group M specific haemagglutinin in pyelonephritogenic Escherichia coli. Lancet 1982 ; 1 : 1192.

8. Korhonen $T K$, Vaisanen-Rhen $V$, Rhen M, Porc A, Parkkinen $J$, Finne $J$. Eacherlchia coli flmbrlae recognizing sialyl galactosides. J Bacteriol 1984; 159: 762-766.

9. Drakov I, brakov F. The serology of Escherichia coll fimbriae. Prog Allergy 1983; 33: 80-105.

10. Jann $K$, Jann $\mathbb{B}$, Schmldt G. SDS-polyacrylamide gel electrophoresis and serologlcal analysis of pill from Escherlchia coll of different pathogenic orlgin. FEMS MLcroblol Lett 1981; 11: 21-25.

11. Czirok. E, orskov I, orskow F. $0: \mathrm{K}: \mathrm{H}: \mathrm{F}$ serotypes of fimbriated Escherichia coli strains 1solated from infants with diarrhea. Infect Immun 1982; 37 : 519-525. 
12. Nimmich $W$, Zingler $G_{\text {m }}$ orskow $I$. Wimbrial antigens of Escherichia coll $01: \mathrm{K} 1: \mathrm{H} 7$ and $01: \mathrm{K} 1: \mathrm{H}-$ strains isolated from patients with urinary tract infections. Zb1 Bakt Hyg $1984 ; 258: 104-111$.

13. de Ree JM, Schwlllens $P$, van den Bosch JF. Monoclonal antibodies that recognize the $\mathbb{P}$ fimbriae $F 7_{1}, F 7_{2}$, F9 and Fli from uropathogenic Escherichia coli. Infect Immun 1985; 50: 900-904.

14. de Ree JM, Schwillens $P$, wan den Bosch JF. Monoclonal antibodies for serotyping the $P$ fimbriae of uropathogenic Eschertchia coll. J Gin Microblo1 1986; 24: 121-125.

15. van den Bosch JF, De PL, Postma P, de Graaff J, Maclaren DM, Jansen WH, Guinee PAM. Wirulence of Escherichia coli in acute pyelonephritis, acute cystitis and asymptomatic bacteriuria. Ant van Leeuwenhoek 1980; 46 : $321-329$.

16. van den Bosch JF, Verboom-Sohmer U, Postma $P$, de Graaff J, Maclaren DM. Mannose-sensitive and mannose-resistant adherence to human uroepithelial cells and urinary virulence of Escherichia coli. Infect Immun 1980; 29: $226-233$.

17. van den Bosch JF, Postma P, van Brenk D, Guinée PAM, de Graaff J, MacLaren DM. Virulence of Escherichia coll strains 1solated from urine of patients with acute cystitis and fron faeces of healthy women. Ant van Lee uwenhoek $1981 ; 47: 97-106$.

18. van Alphen L, van Kempen-De Troye F, and Zanen HC. Characterization of cell envelope proteins and lipopolysaccharldes of Escherlchia coli 1solates from patients with neonatal meningitis.

FEMS Microbiol Lett $1983 ; 16: 261-267$.

19. O'Hanley P, Lark $D$, Nomark S, Falkow $S$, and Schoolnik GK. Mannosesensitive and Gal-Gal binding Escherichia coli pili from recomblnant: strains. J Exp Med 1983; 158: 1713-1719.

20. van den Bosch JF, Postma $P$, de Graaff $J$, and MacLaren DM. Haemolyris by urinary Escherlchia coli and virulence in mice. J Med Microblo1 1981; 14: $321-331$.

21. Ka11enius $G$, M\&11by R, Svenson SB, Helin I, Hultberg H, Cedergren B, and Winberg $J$. Occurence of P-fimbriated Escherichia coll in urinary tract infections. Lancet $1981 ; 2: 1369-1372$. 
22. Svamborg-Edén $C$, hagberg $L$, Hanson LA, Hul1 $S$, Hull $R$, Jodal $X$, Leffler H, Lomberg $\mathrm{H}_{\text {, and }}$ Strabue $\mathrm{E}$. Bacterlal adherence - a pathogenic mechanism In urimary tract Infections caused by Escherlchia coll. Prog Allergy $1983 ; 33: 175-1.88$.

23. Korhonen TK, Valtonen WV, Parkinen J, Valsänen-khen V, Finne J, Ørskov F, Orkow I, Svenson SB, Makela PH. Serotypes, hemolysin production, and receptor recognition of Escherich coll strains associated with neonatal sepsis and meninglt1s. Infect Immun 1985; 48:486-491.

24. Achtman M, Mercer A, Kusecek B, PohI A, Heuzenroeder M, Aaronson $W$,

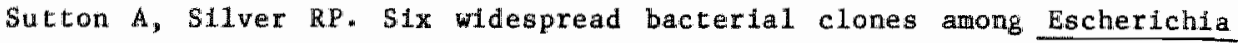
col1 K1 1801ates Infect. Immun. 1983: 39:315-335. 
SEROLOGICAL RESFONSE TO THE P PIMERIAE OR

UROPATHOGENTC ESCHERICHIA COLI IN PYELONEFHRTIIS.

\section{INTRODUCTION}

The ability of uropathogenic Escherichia coli to adhere to uroepithelial cells is a prerequisite for urinary tract infections (UTI) (20,25, 26). The mechanism of adherence has been investigated intensively during the last years. Many investigators support the concept that adherence is mediated by fimbriae, wich attach to speclfic receptors on host cells. The fimbriae of uropathogenic $\mathbb{E}$. coli can be divided into common or type 1 fimbriae that cause a mannose sensitive hemagglutination (MSHA) of guinea plig erythrocytes, and fimbriae that cause a mannose resistant hemagglutination (MRHA) of human erythrocytes. The MRHA fimbrtae can be subdivided into $P$ (13), $M(24)$ and $S$ (12) fimbriae on the basis of their receptor specificity* The $P$ fimbriae recognize the disaccharide $\alpha-\mathrm{D}-\mathrm{Gal} \underline{\mathrm{p}}-(1-4)-\beta-\mathrm{D}-\mathrm{Gal} \underline{\mathrm{p}}$ as a receptor (13) on the uroepithelial cells and it has been reported that the urinary virulence ot $E_{\text {* }}$ coli causing pyelonephritis is mediated by these $P$ fimbriae $(5,23) \cdot P$ fimbriae have been demonstrated in 90 per cent of E. coli strains isolated from children with acute, nonobstructive pyelonephritis $(10,20)$, whereas these $P$ fimbriae are progressively less comon in strains lsolated from cystitis, asymptomatic bacteriuria and faeces (6).

Recently, the role of fimbrlae as a virulence factor of uropathogenic $\mathbb{E}_{\text {. }}$ coll was brought up for discussion by Harber et al. (8). They demonstrated that E. coli strains freshly isolated from the urine were not fimbriated and also nonadhesive. Fron their results they concluded that fimbriae wedlated adherence $1 \mathrm{~s}$ not involved in the pathogenesis of UTI once organisms have entered the urinary tract $(7,8)$. However, these results could also be explained by the selection of patients with urinary tract defects, a group recently shown to have a low percentage of adhesive isolates (19). Further- 
more, the bacteria which express fimbriae wil be attached to epithellal cello and 1 in consequence this adhesive capacicy would ensure that free bacterla in the urine are likely to be non-fimbriate (15). In wiew of the doubts between the fimbrial and non-fimbrial adhesion hypothesis we have Inwestigated whether the $P$ flabriae of uropathogenlc E. coll are synthesized 1n Vivo or not. Therefore, the $P$ fimbriae of $\mathbb{E}$. coll strains isolated from patients th pyelonephritis were serotyped with specific monoclonal antibodles (MAbs) $(3,4)$. Subsequently the serum of these patients was analyzed for the presence of antibodies against homologous and heterologous fimbriae. In all sera antibodies against $\mathbb{P}$ fimbriae were present, strongly suggesting that these flmbrliae are indeed produced in vivo and not merely a laboratory phenomenon. However, these sera did not contain adherence inhibiting antibodies.

PATIENTS, MATERIALS AND METHODS

Patients, bacterlal stralins, and sera.

E. coll strains were isolated from mid-stream urine specimens obtained from four female patients with complaints pointing at pyelonephritis, $\mathbb{1}$.e. loln patn, fever $\left(>39^{\circ} \mathrm{C}\right)$ with chills and nausea. All urine specimens yielded pure growth of $>10^{5}$ colony forming units/ml. Patient 24 (79 years old), patient 25 (23 years) and patient 41 (73 years) had urosepsis, since the same E. coll strain was isolated from urine and blood, as judged by similarity of blotype, antibiotic sensitivity pattern and $0: \mathrm{K}$ serotype. Patient 50 ( 9 years) had a scarred kidney on subsequent radiological examination. Immediately after isolation all strains were stored at $-70^{\circ} \mathrm{C}$ in broth with $30 \%$ glycerol. For laboratory tests the strains were grown on blood agar plates (Oxold). Hemolysis was tested on washed-blood agar plates. Serotyping of 0 and $K$ antigens was pertomed by P.A.M* Guinée (National Institute of public Heal th, Bil thoven, The Netherlands).

Serum specimens were collected from all patients at 6-10 days after the onset of complaints. Control serum consisted of pooled serum from several females thout present complaints or history of UTI.

Hemagglutination and Hemagglutination inhibition assay.

The MaEA activity of the E. coli strains with human erythrocytes was determined by the method of van den Basch et al. (25). Briefly serial dilutions of bacteria were incubated with human erythrocytes in the presence of 
$1 \%$ mannose for 2 h on ice and HA was read after aytution. The lnhibition of MRHA was tested with bacteria preincubated for $30 \mathrm{~min}$ at room temperature with homologous patient serum or polyclonal rabbit anti serum. Polyclonal rabbit antisera raised in rabbits against various purified cloned finbrilae were recently characterized in a fimbriae ELISA (3). Serum dilutions were used which did not cause agglutination of bacteria, as checked by microscopy.

\section{The P-receptor test.}

The fimbriae of the clinical isolates were tested for their ability to recognize the $\mathrm{P}$ receptor $\alpha-D-G a l \underline{p}(1-4)-\beta-D-G a l \underline{p}$. Bacteria grown on blood agar plates were mixed on a glass slide with latex beads coated with the globoside receptor structure. Latex beads devold of the globoside structure were used as a control. If $\mathrm{P}$ fimbriae were present on the clinical isolates macroscoplc agglutimation was apparent within 1 minute. Latex beads coated with the $P$ receptor were kindly supplied by Bjorn Lund, University of Umea, Sweden.

Determination of the fimbriae serotype by monoclonal antibodies.

Recently we developed a set of specific monoclonal antibodies (MAbs) against the serolog 1 cal different $P$ fimbriae (F7-F13) from uropathogenic E. coli (3, 4). The P fimbriae on the isolated E. coll strains were serotyped with the aid of the MAbs in a whole bacteria ELISA as described (4). Briefly, microtiterplates were coated with bacterial suspensions by drylng overnight at $37^{\circ} \mathrm{C}$, washed with salline containing Tween 20 and blocked with $15 \%$ New Born Calf serum in sallne. After thorough washing the microtiterplates were incubated wth $1: 100$ diluted MAb for $2 \mathrm{~h}$ at room temperature * Subsequently the wells were washed and incubated with goat-anti-mouse-IgG (H+L) conjugated to peroxidase (Nordic) for $3 \mathrm{~h}$ at room temperature. The presence of certain fimbriae was detected colorimetrically by adding $0.05 \%$-phenylendianine in citrate/phosphate buffer with $0.005 \% \mathrm{H}_{2} \mathrm{O}_{2}$. The reaction was developed in the dark for 15 minutes at room temperature and teminated with $\mathrm{MM}_{2} \mathrm{SO}_{4}$. The $\mathrm{A}_{492}$ was measured in a Titertek Multiscan (Flow).

Anti-fimbriae antibody titers in serum.

Antibodies against $P$ fumbriae in the serum of the patients were detected with a fimbriae ELISA. All fimbrlae were purffled frot atrains expressing cloned $\mathbb{P}$ fimbriae except the $F 12$ fimbriae which were purifled from the wild type F12 reference strain C1212. The characteristics of the strains, encoding 
for the aerologicaly different cloned $P$ fimbriae, are presented in table 1. All fimbriac were purifled by the method of Korhonen et all. (11) awoiding. protein deraturing conditions (1).

The flmbriae ELISA was performed as described (3). Briefly microtiterplates were coated wh purtifled fimbriae, followed by fincubation with serial dilutions of serum. Antiflmbriae activity was detected colorimetrically after incubation th goat-anti-human immonoglobulins $(H+L)$ conjugated with peroxidase (Nord1c) and addition of the substrate o-phenylenediamine. Absorbance at 495 nim determined with a Titertek Multiscan.

\section{RESULTS}

The E. coll stralns isolated from the four patlents were characterized by their $0: K$ serotype, hemolysin production, the MRHA titer and the ability to recognize the $\mathbb{P}$ receptor (Table 2 ). Two strains belonged to the $01: k 1$ serotype, one to $04: \mathrm{K} 12$ and one to $02: \mathrm{K} 7$. All four strains showed WRHA and expressed $P$ fimbriae. Only one strain produced hemolysin. The F serotype of the $p$ fimbrlae of these four strains was determined by a whole bacteria ELISA uslng spectilc MAbs for $P$ fimbriae. The fimbriae of strain NS24 were recogni-

TABLE 1: Strafns encoding for different $P$ fimbriae, and monoclonal antibodies which recognize specific p fimbriae.

Strain

AM1727 (PPIL 110-70)

AM1727 (PPLL110-37)

AM 1727 (PANN921)

AM1 727 (PPIL288-10)

AM1727 (PPIL291-15)

AM1727 (pRHU845)

C. 979 $(24)^{b}$

(25)

(c)

(28)
Fimbriae

[27 1

17

F.8

E9

E11

F13

F 12
MAbs ${ }^{a}$

M6-8

M2-1

17-9

M4-7

Mi -6

M8-16

14-5

\footnotetext{
a See references 14,15,

$b$ keferences in parenthesis

- Hacker et al. in press.
} 
TABLE 2: Character1st1cs of E. coll strains tsolated from pye lonephrtis patients.

\begin{tabular}{|c|c|c|c|c|c|c|}
\hline strain & Seratype & Hly & MRHA & $P$-test & $\begin{array}{l}\text { Positive reaction } \\
\text { Wh th } \mathrm{MAb}\end{array}$ & $\begin{array}{l}\text { Finbriae } \\
\text { serotype }\end{array}$ \\
\hline $\mathrm{NS} 24$ & $01: \mathrm{K} 1$ & - & + & + & $M 6-8, M 7-6$ & $\mathrm{~F}_{1}, \mathrm{~F} 11$ \\
\hline NS 25 & $04: K 12$ & + & + & + & $M 7-6$ & F 11 \\
\hline MS41 & $02: \mathrm{k} 7$ & - & + & + & $M 6-8$ & F7 1 \\
\hline MS 50 & $01: \mathrm{KI}$ & - & + & + & $14-7$ & F9 \\
\hline
\end{tabular}

TABLE 3: THter of patient sera against homologous ${ }^{a}$ and heterologous $\mathrm{p}$ fimbriae.

\begin{tabular}{lllllllll}
\hline & \multicolumn{6}{c}{ Ant1body } & titer $^{b}$ & to indicated fimbriae \\
\cline { 2 - 8 } Serum of Patient & F7 & F7 & F8 & F9 & F11 & F12 & F13 \\
& & 2.3 & 2.6 & 2.9 & 2.3 & 3.2 & 2.9 & 2.6 \\
24 & 2.0 & 2.3 & 2.6 & 2.3 & 2.0 & 2.3 & 2.0 \\
25 & 3.8 & 3.2 & 2.9 & $>3.8$ & $>3.8$ & 3.5 & 2.9 \\
41 & 2.6 & 2.9 & 2.9 & 3.2 & 3.2 & 3.2 & 2.6 \\
50 & $<1$ & $<1$ & $<1$ & $<1$ & $<1$ & $<1$ & $<1$ \\
Control & 1 & & & & & &
\end{tabular}

\footnotetext{
a Titer against homologou fimbriae are encircled.

$b$ Given as the logarith of the last reciprocal dilution of the antigerwn giving an $A_{490}$ of at least 0.50 .
} 
zed by tho different MAbs (M6-8 and M7-6) whereas the fimbriae of the other stralns were only recognized by one MAb: NS25 by M7-6, NS41 by M6-8 and NS50 by 14-7. From these results we conclude that NS24 expresses F7 and F11 firbriat, NS24 expresses F11 fimbriae, NS41 expresses $F_{1} 7$ fimbriae and NS50 expresses 9 fimbrlae.

Antibody titers against $\mathrm{P}$ fimbriae in the patient sera were deterained by a flmbriae ELISA using the pattent serum as the first antibodies. Fimbriae purtfled fron different recombinant strains and one wild type strain were used as antigen (Table 1). Although there was variation in the titers against the varlous $P$ fimbriae, all sera contained increased homologous and heterologous antifimbriae antibodies compared with the negative control serum (Table 3). The titer of the various sera against the homologous fimbriae was not higher than against the heterologous fimbriae. The titer of the antifimbriae antibodies in the seru of patient 25 was low compared with the other three, but significantly higher than in the control sera.

All four E. coll strains showed a MRHA of human erythrocytes (Table 2 ). This MRHA was almost completely inhibited in the presence of homologous polyclonal rabblt antisera (Table 4). In contrast, the MRHA was not or very poorly inhibited by the homologous patient sera.

TABLE 4: MRHA inhibltion by rabbit and patient sera.

\begin{tabular}{|c|c|c|c|c|c|}
\hline \multirow[t]{3}{*}{ Strain } & \multicolumn{5}{|c|}{ MRHA titer in the presence of } \\
\hline & \multirow[t]{2}{*}{-} & \multirow{2}{*}{$\frac{\text { homologous }}{\text { anti-Ft }}$} & \multicolumn{2}{|c|}{ rabbit antiserum } & homologous \\
\hline & & & anti-F9 & anti-F 11 & patient serum \\
\hline $\operatorname{MS} 24$ & 16 & 2 & & 0 & 8 \\
\hline NS25 & 32 & & & 0 & 32 \\
\hline $\mathbb{N \$ 4 1}$ & 16 & 2 & & & 8 \\
\hline NS 50 & 8 & & 2 & & 8 \\
\hline
\end{tabular}


A few years ago Harber et al. (8) claimed that adherence is not a virulence factor for $\mathbb{E}$. coll bacterla once they have entered the urimary tract, and that adherence flmbriae are not expressed in urine. This view has been ctiticlzed by several groups who have shown a strong association between the capacity of $\mathbb{E}$. coll to express $P$ flmbriae and pyelonephritis $(10,23)$, as we 11 as the involvement of $p$ fimbriae in experimental pyelonephritis (5). Furthermore, two preliminary studies suggested the in vivo expression of $P$ fimbriae by using immonofluorescence labeling of fimbriated $\underline{E}$. coll on volded uroepithelial cells (15) and by direct agglutination of $p$ receptor coated particles with urine sediment (21). In the present study the E. coll isolates and sera of four patients with pyelonephritis were lnvestigated. All four strains showed MRHA and P-speciflc agglutination after one subculture on blood agar. The $F$ serotypes of the expressed $P$ fimbrlae were determined by means of a set of $F$ specific MAbs. Subsequently, the sera of the patients were tested for the presence of antibodies against homologous and heterologous $\mathrm{P}$ fimbriae. In all four sera antibodies were present agalnst homologous as well as heterologous $P$ flmbriae, in contrast to pooled control serum in which no anti-flmbriae antlbadies could be detected. The antibodies were indeed directed against $P$ flmbrlae and not against contaminating type 1 fimbrlae, since the antibodies were measured in a fimbriae ELISA, in which fimbriae were used that were all purlfled from strains expressing cloned $P$ fimbriae, except the F12 flmbrlae. These stralns only expressed the respective $P$ fimbrlae, without expression of type 1 fimbriae. The flmbriae preparations used were pure, as judged by SDS-PAGE and lmunoblotting (1, 3). Also the Fl2 fimbrlae used were pure, whereas contamination with type 1 finbriae could not be detected with MAbs specific for $1 \mathrm{~A}$ and $1 \mathrm{C}$ fimbriae (data not shown). Therefore we conclude that antibodies against $P$ flmbrlae were present in the sera of all four pyelonephritts patients tested, providing strong evidence that $P$ fimbrlae of $\underline{E}$. coll are expressed $1 \mathrm{n}$ vivo. So far only antibodies against type $\mathbb{1}$ fmbrlae have been detected in sera of patients with cyst1tis and pyelonephrit1s $(16,17)$. Unfortunately we were not able to collect serum samples from the patients at different times after onset of complaints. So the determination of possible increase or decrease of antibody titers was not possible.

The antibodies in the patient sera did not only react with the homologous 
Plabriat of the Infecting strains, but also with heterologous $P$ fimbriae. Th1s is not surprising, since antisera raised in rabits against p fimbriae show also many cross-reactions with heterologous $\mathrm{P}$ fimbriae (3). Thus the serologically 1 ifferent $\mathrm{F}$ fimbriae have varlous comon antigenic deteminants besides unlque epitopes. Interestingly, the patient sera did not inhibit the MRHA of the infecting atrains, In contrast to the rabbit antisera. This means that in the patient sera there no or very little antibodies present directed against the actual adhesin. Recently 1 t was found that the adhesins of P Eimbriae are minor components distinct from the fimbriae subunits (22, J.M. de Ree, P. Schwllens, J.F. van den Bosch, Micrablal Pathogenesis, in press). our present results suggest that in vivo these minor components are less irmunogente than the fimbriae.

The possible role of anti-fimbriae antibodies in serum of patients with pyelonephritis is still obscure. Svanborg-Eden et al. (23) have demonstrated. that human polymorphonuclear neutroph11s readily bind bacterla with type 1 fimbriae, but do not bind bacteria with $P$ fimbriae unless opsonized with anti-P fimbrlae antibodies. Thus the ant1-p fimbriae antibodies found in the patient sera, might opsonize the infecting bacteria to improve phagocytosis In kidney and blood stream.

\section{LITERATURE CITED}

1. De Ree, J. M., P. Schwlllens, L. Promes, I. van Die, H. Bergmans, and J.F. van den Bosch. 1985 Molecular cloning and characterization of F9 flobriae from a uropathogenic Escherichia coli. FEMS Microbiol. Lett. 26: $163-169$.

2. De Ree, J. M*, P. Schwlllens, and J. H. van den Bosch. 1985 Molecular cloning of 11 fimbriae from a uropathogenic Escherichia coli and characterlzation of fimbrlae with polyclonal and monoclonal antibodies. FEMS Microbiol. Lett. 29: 91-97.

3. De Ree, J. M., P. Schwllens, and J. F. van den Bosch. 1985 Monoclonal antibodies that recognize the $P$ fimbriae $F 7_{1}, F 7_{2}, F 9$ and $F 11$ from uropathogentc Escherichia coli. Infect. Immun. 50:900-904.

4. De Ree, J. M., P. Schwillens, and J. F. van den Bosch. 1986 Monoclonal antibodies for serotypling the $p$ fimbriae of uropathogentic Escherlchia col1. J. C1in. Microbiol. $24: 121-125$. 
5. Hagberg, L., R. Hull, S. Hul1, S. Fallow, S. Freter, C. Svanborg-Eden. 1983 Contribution of adhesion to bacterial persistence in the mouse urinary tract. Infect. Immun. 40: 265-272.

6. Hagberg, L., U. Jodal, T. K. Korhonen, G. LidH-Janson, U. Lindberg, and C. Svamborg-Edén. 1981 Adhesion, hemagglutination and virulence of Escherichia coli causing urinary tract infections. Infect. Immun 31: $564-570$.

7. Harber, M. J. 1985 Bacterial adberence. Eur* J. Clin. Microblol. 4: $257-261$.

8. Harber, M. J., S. Chick, R. Mackenzle, A. W. Asscher. 1982 Lack of adherence to epithelial cells by freshly isolated urinary pathogens. Lancet 1: $586-588$.

9. Hull, R. A., R. E. Gill, F. Hsu, B. H. Milnshew, and S. Falkow. 1981 Construction and expression of recombinant plasmids encoding type 1 or $\mathbb{D}$ mannose resistant pl11 from urinary tract infection Escherichia coll isolate. Infect. Immun. 33: 933-938.

10. Kallenius, G., R. MU11by, S. B. Svenson, I. Helin, H* Hultberg, B. Cedergren, and $\mathrm{J}$. Winberg 1981 Occurence of $\mathrm{P}$ flmbriated Escherichila col1 in urinary tract infection. Lancet 11: 1369-1372.

11. Korhonen, T. K., E. L. Numiaho, H. Ranta, and C. Svanborg-Edén. 1980 New method for 1solation of Immunologlcally pure plli from Escherichia coll. Infect. Immun. 27:569-575.

12. Korhonen, T. K., V. Vaisunen-Rhen, M. Rhen, A. Porc, J. Parkkinen, and J. Finne. 1984 Escherichia coli fimbriae recognizing sialyl galactosides. J. Bacteriol. 159: 762-766.

13. Leffler, H. and C. Svanborg-Edén. 1980 Chemical identification of a glycosphingolipid receptor for Escherichla coll attaching to human urinary tract ept thelial cells and agglutinating human erythrocytes. FEMS Microbiol. Lett. 8: 127-134.

14. Orskov, I., and F. Orskov. 1983 The serology of Escherichia coli fimbriae. Progr. Allergy 33: 80-105.

15. Parry, S. H., and D. M. Rooke. 1985 Adhesins and colonization factors of Escherichia coli. In: Sussmann $M$, ed. The virulence of Eacherichia coll. London: Academ1c Press, :79-155.

16. Rene, P., M. Dinolfo, and F. J. Silverblatt. 1982 Serum and urogenital antibody responses to Escherichia coli p111 in cyititis. Infect. Inmun. $38: 542-547$. 
1). Rene, $F .$, and F. J. S1lverblatt. 1982 Serological response to Escherichia coll plli in pyelonephritis. Infect. Immun. 37: 749-754.

18. Svanborg-Eden, C., L. M. Bjursten, R. Hul1, S. Hull, K. E. Magnusson, Z. Moldovano, and $H$. Leffler. 1984 Influence of adhesins on the interaction of Escherichia coll th human phagocytes. Infect. Immun. 44: 672-680.

19. Svanborg-Eden, C., L. Hagberg, L. A. Hanson, S. Hull, R. Hull, Y. Jodal, H. Leffler, $\mathbb{H}$. Lomberg, and E. Straube. 1983 Bacterlal adherence - a pathogenic mechanisin in urinary tract infections caused by Escherichia coll. Progr. Allergy 33:175-188.

20. Svanborg-Edén, C., L. Hagberg, L. A. Hanson, T. K. Korhonen, H. Leffler, and $\mathrm{S}$. 0111ng. 1981 Adhesion of Eschertchia coll in urinary tract infection. In: Elliott $K$, ed.: Adhesion and microorganism pathogenicity. Ciba Foundation Sympositum, P1tman Medical, London, vol. 80, 161-187.

21. Svenson, S. B., G. Kallenius, R. Hellby, H. Hultberg, and J. Winberg. 1982 Rapld Identiflcation of P-fimbriated Escherichia coli by a receptor speciftc particle agglutination test. Infection 10:209-214.

22. Uh1in, B. E., M. Norgren, M. Baga, and S. Normark. Adhesion to human cells by wschertchia coll lacking the major subunit of a digalactoside speciflc adhesin. Proc. Nat. Acad. Sci. USA 82: 1800-1804.

23. Walsanen, V., J. Elo, L. G. Tallgren, A. Siltonen, P. H. Makela, C. Svanborg-Edén, G. Kallenius, S. B. Svenson, H. Hultberg, and T. K. Korhonen. 1981 Mannose resistant hemagglutination and $P$ antigen recognition are characteristic of Escherichia coli causing prinary pyelonephritis. Lancet if: 1366-1369.

24. Vaisanen, V., T. K. Korhonen, M. Jokinen, C. G. Gahmberg, and C. Ernholm. 1982 Blood group $M$ specific hemagglutinin in pyelonephritogenic Bscher Ich1a coll. Lancet 1: 1192.

25. Van den Bosch, J. F., P. Postma, P. A. R. Koopman, J. De Graaff, D. M. Maclaren, D. G. Van Brenk, and P. A. M. Gulnée. 1982 Virulence of urinary and faecal Escherichla colf in relation to serotype, hemolysis and hemagglutination.. J. Hyg. 88: 567-577.

26. Van den Bosch, J. F., U. Verboom-Sohmer, P. Postma, J. De Graaff, and D. M. Macharen. 1980 Mannose sensitive and mannose resistant adherence to human uroepithelial cells and urinary virulence of Escherichla coll. Infect * Immun. 29:226-233. 
27. Van Die, I*, G. Splerings, I. Van Megen, E. Zuidweg, W. Hoekstra, and H. Bergmans. 1985 Cloning and genetic organization of the gene cluster encoding FT $_{1}$ fimbrlae of a uropathogenic Escherichia coll and comparison with the $E 7_{2}$ gene cluster. FEMS Microblol. Lett. $28: 329-334$.

28. Van Die, I., I. Van Megen, W. Hoekstra, and H. Bergmans. 1984 Molecular organization of the genes involved in the production of $F 7_{2}$ fimbriae, causing manmose resistant hemagglutination, of a uropathogenic Escherlchla col1 06:K12:H1:F7 strain. Mol. Gen. Genet. 194: 528-533. 
The ablitty of pathogenic organisms to colondze a mucous membrane is a prerequilite for most infections. To colonize a mucous membrane bacteria belongling to the normal flora as 11 as pathogens have to adhere to epithellal cells to persist in their habitat, and not to be removed by clearing mechanisms 11 ke pertstalsts, tucous secretions or other fluids, e.g * urine. Most bacteria have evolved adhesins to overcome the clearing mechanisms. With the adhesins the bacterla can recognize specific receptors, usually carbohydrates on the epithelial cells. The surfaces of the eptithellal cells are covered with a great variecy of carbohydrates, where they can act as receptors. The molecular basis of the receptor structures are under investigation, and some of these spectictc receptor structures are elucidated (1-4).

For many bacteria the adhesins have been characterized as proteinacaus appendages called rimbriae. Among uropathogenic Escherichia coll strains espectally the $P$ fimbriae have been assoclated with pyelonephritis. This thesls describes the molecular and especlally the serological characterization of the various $P$ fimbriae of uropathogenic $\mathrm{E}$. col1. The maln goal of this study was to develop a set of speciflc antibodies against the serolog1cally different $P$ flmbrlae. Wth these specific antibodles the presence of $\mathbb{P}$ fimbriae on uropathogenic E. coll strains and the role of $p$ fimbriae in the pathogenesis of pyelonephrits could be studled.

At the onset of this study we planned to reach the ultimate goal by purifying the p'fimbrie from uropathogenic E. coll strains and to ralse polyclonal antisera against these purifled fimbriae. Subsequently, these antisera could be made fimbriae specific by absorption techniques. However, each wildtype E. coll strain often expresses various serologlcelly different $p \mathrm{flm}^{-}$ brlae together wth type 1 fimbriae, which makes 1 t extremely difficult to purlfy one spectflc type of $P$ fimbrlae. Furthermore, purification of fimbriae 
from wild-type straias in general yielded low amounts of fimbrlae. For these reasons we decided to clone the genes encoding for the varlous types of $P$ flmbriae. Subsequently, a gene cluster encoding for specific $P$ fimbriae was. transfomed to an $\underline{\text { E. coli }}$ K12 strain which does not produce any kind of fimbriae (Chapter 2 and 3 ). This molecular cloning of the genes encoding for a certain type of $P$ fimbriae made it possible to purify all serologically different $\mathrm{P}$ fimbriae separately. Furthermore, the cloning of the genes clusters, encoding for the P fimbriae, on high copy plasmids increased the production of the fimbriae, which made it possible to purify large amounts of these fimbriae.

Polyclonal rabbit antisera raised against these purifled cloned $\mathrm{P}$ fimbriae still showed many cross reactions against heterologous $\mathrm{p}$ fimbriae (Chapter 4). For this reason we started to produce monoclonal antibodies (MAbs) against the varlous purified $P$ fimbriae (Chapter 4-6). Most of these MAbs recognized only an epitope on the homologous P fimbriae. From the se spectic MAbs we selected a set of MAbs for serotyping the $P$ fimbriae of clinical E. coli 1solates (Chapter 7). Wth these MAbs we we able to identify approximately $70 \%$ of the P fimbrlated urinary E. coli 1 solates (Chapter 8). The most common serotypes of the $P$ fimbriated urinary tract infections (UTI) strains were the F11, F/ 1 , and F8 fimbrlae. However, it is still difficult to draw definite conclusions about which of the $P$ fimbriae are the most important in the pathogenesis of UTI, due to the relatively small collections that were screened so far.

The sera of four patients wh pyelonephritis were analyzed for the presence of specific antibodies against the $P$ fimbriae (Chapter 9). In all cases antifimbrlae antibodies were found, which strongly suggests that these $p$ fimbriae are expressed in vivo and are not merely a laboratory phenomenon. However, the antibodies did not Inhibit adherence, Indicating that these antibodies were directed agalnst the fimbriae protelns rather than to the "minor components" responsible for adherence.

Recently, several gene clusters encoding for $P$ flmbrlae were analyzed (5-9). Surprisingly, mutations in the fimbriae subunit gene did not abolish the adheston to uroepithelial cells, although such mutants are unable to produce flmbriae. In contrast, mutants with lesions in two downtream genes were able to synthesize flmbriae but completely lost the ability to adhere to uroepithellal cells (10). This strongly suggests that these two genes encode for minor components Involved in adhesion, and that the fimbriale itself are 
not the actuall adhesins.

In Chapter 6 some MAbs are described which recognize an epltope on the winor components wich are lnwolved in adhesion. These MAbs were able to Inhibit adhesion, whereas the fimbriae speciflc MAbs did not inhibit adhesion. Most anti-fimbriae MAbs described in this study reacted only with homologous flmbrlae whereas the MAbs which recognize the minor components Involved In adheston showed a cross reaction wh three different finbriae. This suggest that the minor components may have a more conservative structure compared with the $P$ fimbriae which are more susceptible to antigenic varlation.

All the assays used In this study for the detection of $P$ flmbrlae on uropathogenic $E$. coll tere phenotyplc assays. The disadvantage of phenotypic assays is that they do not demonstrate whether or not the genetic information for the expression of fimbriae ls present in the bacteria. For E. coli stralns expressing type 1 flmbriae it has been described that these bacteria can switch from a fimbriated phenotype to a non-fimbriated phenotype, a process called phase varlation $(11)$. It has also been described that a strain with a speciflc P flmbrlae serotype was able to switch to a type $1 \mathrm{C}$ fimbrlae serotype (12), and o'Hanley et al. (13) showed that expression of P fimbriae required four or more passages in vitro in $40 \%$ of the strains tested. Thus, phase varlations in the fimbriae phenotype may result in an underestimation of the percentage of $P$ flmbriae expressing strains among strala collections when only phenotyplc assays are used. This can be circumvented by using phenotypic assays in combination with genotyplc assay. With a DNA probe encoding for the $P$ fimbrlae gene cluster it is possible to demonstrate whether the strains expressing a non-fimbriate phenotype, do have the genetic Informtion for expresion of $\mathrm{P}$ flubrlae on the chromosome or not.

Preliminary experiments have shown that th a DNA probe it is indeed possible to demonstrate that the information for $P$ flmbriae is present in a

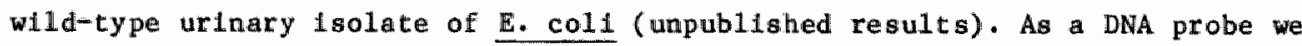
used a part of the $7_{1}$ gene cluster which encoded for a conserved reglon. With this probe we were able to demonstrate 1 in a Southern blot (14) that the reference strain for F12 fimbriae, C1979, possesses the information for $P$ Imbrlae on the chromosome. Other studies have also shown that it is possible to construct probes from the conserved reglons which hybrldize with all the different $P$ fimbrlae genes, for use in 1 dentifying potentlally $P$ fimbriated strains $(13,15)$. 
As described above the developed MAbs against the filmbiae can have, in combination with a genotypic assay, great value for diagnostic and epideniological studies. With the set of $P$ fimbrlae specific MAbs the $0: k: H$ serotyping for E. coli can easily be extended with the F serotype.

Recently, much interest has been focussed on $\mathrm{P}$ fimbriae as a candidate for a vaccine against pyelomephritis. In vitro studies have demonstrated that antibodiles which bind to the fimbriae (16, Chapter 4) or to the minor components involved in adhesion (Chapter 6) inhlbit the assoclation between the adhesins and the receptors. In vivo, anti-fimbriae antibodies have been shown to inhlbit or delay experimental infection in monkeys and mice (16-18). Based on these in vivo and in vitro studies it was suggested that the fimbrlae might be used for vaccination against pyelonephrttis. Howewer, several problems have to be considered with regard to development of a vaccine, e.g. antigenic variation of the $P$ fimbrlae; the difference between fimbriae and actual adhesins; the target population; and the route of vacclnation.

As shown in Chapter 8 , we were able to 1dentify approximately $75 \%$ of the $P$ fimbriae on urinary 1solates with 9 different MAbs. Thus, at least 10 serologlcally different $P$ flmbrige may be involved in the pathogenestis of pyelonephrltis. Although polyclonal antisera showed many cross reactions with different $F$ types of $P$ fimbriae (Chapters 4 and 9 ), it was shown in Chapter 9 that in vivo developed ant1-P fimbrlae antibadies will not always be antiadhesive for the infecting $\mathbb{E}$. coli strains. Therefore, it seems logical that a possible vaccine has to be based on the minor components which are responsible for adherence, rather than on the fimbriae itself. An advantage might also be that the minor components have less antigenic variation than the fimbriae, since the anti-adhesive MAbs described in Chapter 6 showed cross reaction with winor components of three different $\mathbb{P}$ fimbrita.

With regard to the target population for vaccination one has to be aware of the finding that $\mathbb{P}$ fimbrlae are mainly of 1 mortance in the pathogenesis of pyelonephritis in the non-compromised host. Although most studieg agree on the association between $P$ flmbriae and acute pyelonephritis in young children $(19,20)$, less agreement exists on the association wth lower UTI (19, 20) or with UTI in elderly patients (21, Chapter 8$)$. Furthermore, Lomberg et al.

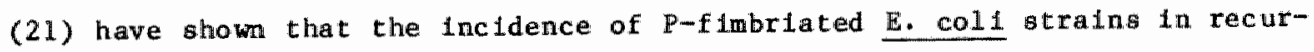
rent pyelonephritis patients with vestcoureterlc reflux 1 s only $25 \%$ compared with $50 \%$ in such patients whout reflux. Therefore, vaccination may only be effective in patients whout urological disorders. 
Wth regard to the route of vaccination, recentiy a new approach was proposed by vehling et al (22). In contrast to other studies using parenteral vaccination, Jehling et al. administered a vaccine into the vagina of monkeys. They suggested that this local vaccine application will result into a local mucosal sIgA response which might prevent colonisation by pathogenic P-flimbriated $\mathbb{E}^{-}$coll of the perturethral zone and the bladder.

In conclusion, not only the pathogenesis of $\mathbb{E}$. coli pyelonephritis is multi-factoral (23), but also the role of adherence in the pathogenesis is very complicated. Obviously, more research is needed to reach the ultimate goal, the proper management and prevention of UTI.

\section{LITERATURE CITED}

1. Lindah1, M. 1986. The carbohydrate specificity and hydrophobic properties of $K 99$ and $F 41$ fimbrlae of enterotoxigenic E. col1. Thesis. University of Agricultural Science, Uppsala.

2. Leffler, H., and C. Svamborg-Edén. 1980. Chemical identification of a glycosphingollpid receptor for Escherichla coli attaching to human urinary tract epithelial cells and agglutinating human erythrocytes. FEMS Microbiol. Lett. 8: 127-134*

3. Korhonen, T.K., V. Vaisanen-Rhen, M. Rhen, A. Porc, J. Parkkinen, and J. Finne. 1984. Escherichia coli fimbriae recognizing sialyl galactosides. J. Bacter101. 159: 762-766.

4. Duguid, J.P*, S. Clegg, and M.I. Wilson. 1979. The fimbrial and nonfimbrlal haemagglutinins of Escherichia coli. J. Med. Microbiol. 12: 213-227.

5. Clegg, S*, and J.K. Plerce. 1983. Organization of genes responstble for the production of mannose resistant fimbriae of a uropathogenic Escherichia coll 1solate. Infect. Immun. 42: 900-906.

6. Normark, S., D. Lark, R. Hull, M. Worgren, M. Baga, P. D'Hanley, G. Schoolnik, and S. Falkow. 1983. Genetics of digallactoside binding adhesin from a uropathogenic Escherichla coll strain. Infect. Immun. 41: 942-949.

7. Van Die, I., G. Splerings, I. van Megen, E. Zuidweg, W. Hoekstra, and H. Bergmans. 1985. Cloning and genetlc organization of the gene cluster encoding F7, flmbriae of a uropathogenic Escherichia coli and comparison with the $\mathrm{FT}_{2}$ gene cluster. FEMS Microbiol. Lett. 28: 329-334. 
8. Van Die, I., C. Van der Hondel, H.J. Hamstra, Wo Hokstra, and H. Bergmans. 1983. Studies on the fimbrlae of an E. coll 06:K2:H1:F7 stralu: molecular cloning of a DNA fragment encoding a fimbrial antigen responslble for mannose resistant hemagglutination of human erythrocytes. Fus Microbiol. Lett. 19: 77-82.

9. Van Die, I., I. van Megen, W. Hoekstra, and H. Bergmans "1984. Molecular organization of the genes involved in the production of $\mathrm{F} 7_{2}$ flmbrlae, causing mannose resistant hemagglutination of a uropathogenic E. coll 06:K2:H1:F7 strain. Mol. Gen. Genet. 1984: 528-533.

10. Uhlin, B.E., M. Norgren, M. Baga, and S. Normark. 1985. Adhesion to human cells by Escherichia coli lacking the major subunit of a dgalactoside specific pilus adhesin. Proc. Nat1. Acad. Sc1. USA 82: 1800-1804.

11. Klemm, P. 1986. Two regulatory fim genes, flab and fimf, control the phase variation of type I fimbriae in Escherichla coli. EMBO J. 5: $1389-1393$.

12. Nowick1, B., M. Rhen, V. Valsanen-Rhen, A. Pere, and T. Korhonen. 1984. Immunofluorescence study of fimbial phase variation in Escherichia col1 KS71. J. Bacterto1. 160: 691-695.

13. O"Hanley, P., D. Low, I. Romero, D. Lark, K. Vosti, S. Falkow, and G. Schoolnik. 1985. Gal-Gal bilnding and hemolysin phenotypes and genotypes associated with uropathogentc Escherichia coll. N. Eng1. J. Med. 313: 414-420*

14. Southern, E.M. 1975. Detection of speciflc sequences among DNA fragnents separated by gell electrophoresis. J. Moll. Bial. 98: 503-517.

15. Ekbäck, G., S. Mörner, B. Lund, and S. Normark. 1986. Correlation of genes in the pap gene cluster to expression of globoside-specific adiesin by uropathogenic Escherichla col1. FEMS Micrablo1. Lett. 34: 355-360.

16. Svanborg-Eden, C., B. Andersson, L. Hegberg, L.A. Hanson, H. Louberg, H. Leffler, G. Magmusson, G. Noori, J. Dahmen, T. Soderström. 1983. Receptor analogues and anti-pi11 antlbodies as lohibitors of bacterial at tachment in vivo and in vitro. Proc. N.Y. Acad. Sc1. 409: 580-592.

17. Svarborg-Edén, C., R. Freter, L. Hagberg, R. Hu11, S. Hull, H. Leffler, and G. Schoolaik. 1982. Inhibition of experimental ascending urinary tract Infections by an epthellal cell-surface receptor analogue. Nature 298: $560-562$. 
18. Roberta, J.A., K. Hardawa, B. Kaack, E.N. Fussel, G. Baskin. 1984. Prevention of pyelonephritis by immization with $\mathrm{P}$ fimbriae. J. Urol. 131: $602-607$.

19. Vulsanea, V., J. Elo, G. Tallgren, A. Siltonen, P.H. Măkela, C. Svanborg-Eden, G. Kallentus, S.B. Svenson, H. Hultberg, and T.K. Korhonen. 1981. Mannose-resistant haemagglutination and $P$ antigen recognitlon are characteristic of Escherichia col1 causing primary pyelonephrit1s. Lancet 11: 1366-1369.

20. Kä1len1us, G. R. Mo11by, S.B. Svenson, I. He11n, H. Hultberg, B. Cedergren, and J. Wibberg. 1981. Occurence of P-fimbriated Escherichia col1 in urinary tract infections. Lancet 11: 1369-1372.

21. Lomberg, H., L.A. Hanson, B. Jacobsson, U. Jodal, H. Leffler, C. Svanborg-Edén. 1983. Correlation of $\mathrm{P}$ blood group, vesfcoureteral reflux, and bacterial attachment 1 n patients with recurrent pyelonephritis. $N$. Eng1. J. Med. 308: 1189-1192.

22. Uehling, D.T., and W.J. Hopkins. 1986. Vaginal vacclne aga1nst monkey UTIs. Current Toplc ASM News 52: 330.

23. van den Bosch, J.F., P. Postma, P.A.R. Koopman, J. de Graaff, and D.M. MacLaren. 1982. Virulence of urinary and faecal Escherichia coli in relation to serotype, haemolysis and haemagglutination. J. Hyg. 88: $567-577$. 
De bacterle Eschertchia coll is een van de belangrijkste verwekkers van urineweginfecties. De uropathogene $\mathrm{E}$. coll bacteriên hebben een aantal virulentle elgenschappen ontwikkeld, waardoor ze in staat zijn om vanuit de faeces wa de urethra de urinewegen te infecteren. Een van deze virulentie factoren is het aanhechtend vermogen van de E. coli bacteriën aan het urinewegep1thee1. De anhechting vindt plaats met behulp van $P$ finbriae, waardoor de bacterlen zlch speciflek aan receptoren op het urinewegepitheel kunnen hechten. Tot nu toe $21 \mathrm{jn}$ er \pm 10 serologisch verschillende soorten $P$ fimbriae beschreven.

Het doel van het onderzoek, beschreven in dit proefschrift, was een set van antisera te ontwikkelen gericht tegen de verschillende $\mathrm{P}$ fimbriae. Met behulp van deze set van antisera kunnen de $P$ fimbriae aanwezig op de uropathogene $\underline{E}$. coll geserotypeerd worden en kan de rol van $P$ fimbriae in de pathogenese van pyelonephritis bestudeerd worden.

De meeste uropathogene $E$. coli bacterièn zijn in staat om verschillende seratypen van deze $P$ fimbriae tot expressle te brengen, waardoor de zuivering van én type $P$ fimbrlae bemoeilijkt wordt. Bovendien is het aantal tot expressle gebrachte $P$ flmbrlae op de uropathogene E. coli gering, waardoor de opbrengst aan zuivere p fimbriae na lisolatie liag is.

Om deze redenen werd beslloten om de genen coderend voor sén type $P$ flambriae te cloneren en te transformeren naar een $\underline{E}$. coll $\mathrm{K} 12$ stam die geen flmbriae kan produceren (Hoofdstuk 2 en 3). Hierdoor werd het mogelijk om alle serologisch verschillende $P$ fimbriae afzonder11jk te zuiveren. De genen clusters coderend voor de $\mathrm{P}$ fimbrlae werden gecloneerd in high-copy plasmiden, wardoor relatief grote hoeveelheden $P$ fimbrlae konden worden gezuiverd.

Polyclomale antisera opgewekt tegen de gezulverde $p$ fimbrlae reageerden 
met de homologe, maar ook met de meeste heterologe p fimbriae (Hoofdstuk 4 ). Daarom werd gestart met de produktie van monoclonale antilichamen (MAbs) gericht tegen de verschillende $P$ fimbriae (Hoofdstuk 4-6). De meeste van deze MAbs reageerden alleen met de homologe $P$ fimbriae. Uit deze fimbriae specifleke MAbs werd na selectie een set van MAbs samengesteld voor serotypering van $P$ fimbriae van uropathogene E. coll isolaten. Voor deze serotypering werd een eenvoudige methode ontwikkeld waarin hele bactertien in een ELISA werden gebrulkt (Hoofdstuk 7). Vervolgens werden de $\mathbb{P}$ fimbriae geserocypeerd van enkele oude en nieuwe collectles van uropathogene E. coll stammen (Hoofdstuk 8). Met behulp van de set wan 9 verschillende specifleke MAbs bleek het mogelijk om meer dan $70 \%$ van de P fimbriae van uropathogene E te serotyperen. De meest voorkomende serotypen in deze collecties waren de $F 11, F 7_{1}$ en $F 8$ fimbriae. In veel gevallen bleek een bepaald F type geassocleerd te $z i j n$ met bepaalde $0: K$ serotypen.

De sera van vier patienten met pyelonefritis werden geanalyseerd op de aanwezigheid van specifleke antilichamen gericht tegen $P$ fimbriae (Hoofdstuk 9). In alle sera werden deze anti-p fimbriae antilichamen gevonden. Dit suggereert dat de $P$ fimbriae zowel in vitro als in wivo gevormd worden. De antilichamen in deze sera waren niet in staat om de aanhechting van de uropathogene $\underline{E}$. coll aan urinewegepitheelcellen te remmen. Deze antilichamen zijn dus waarschijnlijk gericht tegen de $P$ fimbrlae en niet tegen de componenten in de $\mathrm{P}$ fimbrlae die verantwoordelijk zijn voor de aanhechting. Alle P flmbriae specifieke Mabs bleken niet in staat de aanhechting van homologe clones te remmen.

In Hoofdstuk 6 werden echter ook een aantal MAbs beschreven die de aanhechting wèl bleken te remmen en dus een epitoop herkennen op de elwitten die betrokken zijn bif de aanhechting aan het urinewegepitheell. In tegenstelling tot de $P$ flubrlae specifleke MAbs reageerden deze MAbs nlet alleen met de homologe $\mathbb{P}$ flmbriae maar ook met een aantal heterologe $p$ flmbriae. Dit suggereert dat de structuur van de componenten, die verantwoordelijk z1jn voor de aanhechting, meer geconserveerd is dan de structuur van de $p$ fimbiae. 
Bif het gereed komen van dit proefschrift wil ik liedereen bedanken die op enlgerlei wijze een bijdrage hebben geleverd. Het zou te ver voeren om ledereen bif naam te noemen, maar eem aantal uitzonderingen wilde $1 \mathrm{k}$ toch wel maken.

Han van den Bosch, mijn copromotor, wil ik bedanken voor de deskundige en kritlsche begeleiding, dle tk als zeer prettig en leerzaam heb ervaren. Daarnaast stond hij mij bij met raad en daad, bij de ultvoering van de vele experimenten. Na $z i j n$ vertrek uit Maastricht, heeft hij vele uren van $z 1 j n$ vrije tijd besteed aan de correctle van de manuscripten, wat $\mathbb{1 k}$ zeer gewardeerd heb.

Cees van Boven, mijn promotor, ben $1 \mathrm{k}$ erkentelijk voor $z i j n$ belangstelling voor mijn onderzoek en de begeleiding gedurende het bewerken wan het proefschrift.

Hans Valkenburg, wijn tweede promotor, dank ik voor zijn belangstelling en betrokkenheld woor mijn onderzoek.

In het blyzonder dank ik Paul Schwilens voor de ultwoering van de vele fimbrlae lsolaties en ELISA's, en voor de plezierige samenwerking.

De samenterking met de vakgroep Moleculalre Celbiologie, sectie Microblologle, R.U. Utrecht, In het bijzonder Wlel Hoekstra, Hans Bergmans, Irma van Die en Nico Rlegman, was woor mij erg lnspirerend. De tijd die ik gedurende de eerste 8 maanden van dit onderzoek op hun lab heb doorgebracht, was yoor mij bljzonder leerzaam en ik dank hen voor de gastvrijheld en samenwerking .

Dr. P.A.M. Guinée en Wim Jansen dank 1 k voor hun belangstelling voor mijn onderzoek en het serotyperen van de uropathogene E. coli stamen.

Veel dank ook aan Fia claus voor haar voortreffelijk typewerk en het bespelen van de tekstverwerker bij het zetklaar maken van het proefschrift. 
Lllian Kreusch en Carla Hendrix ben ik dankbarar voor het uittypen van de manusicripten en de vele correcties.

Luuk Promes en Paul Savelkoul ben ik damkbaar voor de enthousiaste wijze warmee zij als student hebben bijgedragen aan dit onderzoek.

De Nier Stichting Nederland ben ik erkentelijk voor de flnanciele ondersteuning van het onderzoek en de financiele bijdrage voor het bljwonen van een aantal congressen.

Tot slot wil ik diegene bedanken waraan dit proefschrift is opgedragen. Mijn ouders boden mij de gelegenheld on mijn studie te voltoolen en ik ben hen zeer dankbaar voor hun steun en interesse. Het elndprodukt van mijn hobby Iigt nu voor jullie!

Lieve Jeannette, de vele uren die ik besteed heb an dit proefschrift, waren voor ons samen bedoeld. Ondanks de chronlsche verwaarlozing van onze relatle van mijn kant, ben je mij altijd blijven steunen war $1 k$ je erg dankbaar voor ben.

19 december 1986

Han de Ree 


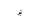


Han de Ree is geboren op 16 juni 1956 te sittard.

1973

1975

1975-1982

Maart 1979

Apri1 1982

1981

me:1 1982 -

december 1985

Vamaf $1-12-1985$
Diploma HAVO aan het Bisschoppelijk college te sittard. Diploma Atheneum-B aan het Blsschoppelifk College te Sittard.

Studle Biologie aan de R.U. Utrecht. Kandidat sexamen $B 4$.

Doctoralexamen B1ologie warvoor het volgende onderzoek werd verricht:

- Scheikundige Dierfysiologie ( 9 mndn)

Dr. A.J. de Mik-Van der Plas en Prof.Dr. P.A. Voogt.

- Microblologie ( 9 mndn)

Dr. H. Bergmans.

- Blochemie (6 mndn)

Dr. P. Franck en Dr. J.A.F. op den Kamp.

Diploma "Stralingsbeschermingsdeskundige C-laboratoria" aan het Interuniversitair Reactor Instituut te Delft.

Aansteling als wetenschappelijk assistent bij de capaciteitsgroep Medische Mcrobiologie, R.U. Limburg, war het hier beschreven onderzoek werd uitgevoerd.

Post-doctoral onderzoek aan het Laboratorium Moleculatre Biologie van de K.U. Nijmegen, war onderzoek wordt verricht aan de structuur en de expressie van genen van de malarta parastet. 